\title{
Debtor Discharge and Creditor Repayment in Chapter 13
}

\section{Scott F. Norberg}

Florida International University College of Law

Andrew Velkey

Follow this and additional works at: https://ecollections.law.fiu.edu/faculty_publications

Part of the Bankruptcy Law Commons

\section{Recommended Citation}

Scott F. Norberg and Andrew Velkey, Debtor Discharge and Creditor Repayment in Chapter 13, 39 CREIGHTON L. REV. 473 (2006).

Available at: https://ecollections.law.fiu.edu/faculty_publications/229 


\section{HEINONLINE}

Citation: 39 Creighton L. Rev. 473 2005-2006

Provided by:

FIU College of Law

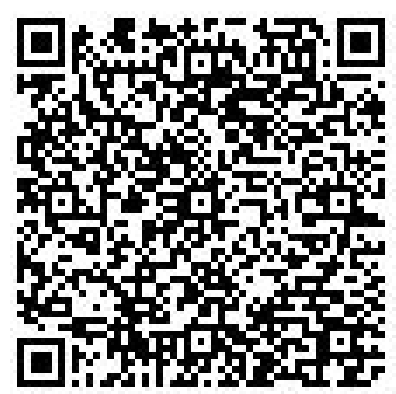

Content downloaded/printed from

HeinOnline (http://heinonline.org)

Fri Jun 10 14:45:23 2016

-- Your use of this HeinOnline PDF indicates your acceptance of HeinOnline's Terms and Conditions of the license agreement available at http://heinonline.org/HOL/License

-- The search text of this PDF is generated from uncorrected OCR text.

-- To obtain permission to use this article beyond the scope of your HeinOnline license, please use:

https://www.copyright.com/ccc/basicSearch.do?

\&operation $=$ go\&search Type $=0$

\&lastSearch $=$ simple\&all $=$ on\&titleOrStdNo $=0011-1155$ 


\title{
DEBTOR DISCHARGE AND CREDITOR REPAYMENT IN CHAPTER 13
}

\author{
SCOTT F. NORBERG† \\ AND ANDREW J. VelKey††
}

I. INTRODUCTION

II. SUMMARY AND HIGHLIGHTS OF PROJECT

FINDINGS ..............................

A. Debtor Discharge ...................... 476

B. Creditor Repayment................... 477

C. Profile of the Debtors...................... 478

D. The Bankruptcy Abuse Prevention and

Consumer Protection Act of 2005 ........... 478

III. DESIGN AND METHODOLOGY OF THE STUDY .. 479

IV. PROFILE OF CHAPTER 13 DEBTORS .......... 482

A. Gender and Household Size of Petitioners....... 483

1. Gender ........................... 483

2. Household Size .................... 484

3. Number of Dependents ............... 485

B. Income and Indebtedness .................. 486

1. Debtor and Household Income ........... 486

2. Income and Gender ................... 488

3. Debtor Indebtedness ................... 489

4. Debt-Income Ratio ................... 491

5. Home Ownership .................... 494

C. Previous and Subsequent Bankruptcy Filings .... 496

1. Other Filings (Previous or Subsequent to the Sample Case) ....................... 497

2. Other Filings - District Comparisons........ 498

3. Abuse by Repeat Filers? .............. 499

4. Chapter, Timing, and Outcome of Other

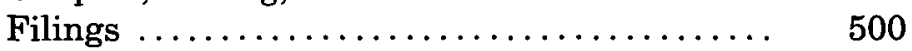

a. Chapter of Other Filings $\ldots \ldots \ldots \ldots \ldots .500$

\footnotetext{
$\dagger$ Professor of Law, Florida International University College of Law.

t† Professor of Psychology, Christopher Newport University.

The Project was funded by the National Conference of Bankruptcy Judges Endowment for Education and by the American Bankruptcy Institute. In addition, the Florida International University College of Law provided generous financial support. The authors also acknowledge Clare Eng and Camilla Chan for their excellent research assistance in the collection and coding of the Project data. We also wish to thank the many Chapter 13 trustees, chief bankruptcy judges, bankruptcy court clerks, and regional United States Trustees in the seven judicial districts included in the Project for their assistance in collecting and reviewing the Project data.
} 
b. Timing of Other Filings .............. 501

c. Outcome of Other Filings ........... 502

5. Filings After Discharge in the Sample Case .. 503

6. The "True" Rate of Chapter 13 Filings ...... 503

V. DEBTOR FRESH START IN CHAPTER $13 \ldots \ldots \ldots .504$

A. Measuring Debtor Success in Chapter 13 ....... 504

B. Debtor and District Discharge Rates in Chapter 13 - All Cases ................... 505

C. Debtor and District Discharge Rates - Cases with a Confirmed Plan ................... 506

D. Relationship Between Pre-Confirmation

Dismissal and Discharge Rates ............. 508

VI. PREDICTING OUTCOME IN CHAPTER 13 CASES

A. Debtor Characteristics and Case Outcome ...... 510

1. Gender, Joint Filing Status, and Case Outcome ........................... $\quad 510$

2. Debtor and Household Income ........... 511

3. Creditor Claims and Case Outcome ........ 512

4. Debtor and Household Debt-Income Ratio .... 515

B. Other Bankruptcy Filings and Case Outcome .... 517

C. Chapter 13 Plan Provisions and Case Outcome... 520

1. Plan Payments and Debtor and Household Retained Income.......................

2. Proposed Distributions to Unsecured Creditors ........................... $\quad 523$

3. Proposed Plan Length ................ 526

4. Time Spent in Chapter 13 .............. 529

D. Other Variables ......................... 531

VII. DEBT COLLECTION IN CHAPTER $13 \ldots \ldots \ldots \ldots .531$

A. Chapter 13 Trustee Disbursements-the

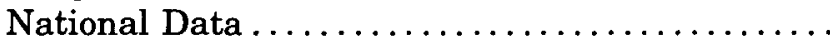

1. Disbursements to Creditors and Chapter 13

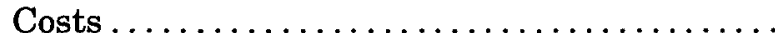

2. Disbursements per Case .............. 537

B. Chapter 13 Trustee Disbursements in the Seven Sample Districts/EOUST and AO Data ....

C. Trustee Disbursements in the Seven Sample

Districts/Project Data.......................

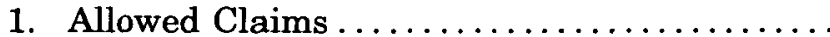

2. Disbursements Per Case and Overall in Chapter 13 Project Cases ..................

a. All Sample Cases ....................

b. Cases with a Confirmed Plan 
c. Completed Cases...................

3. Relationship Between Case Disposition and Creditor Repayment ...................

APPENDIX A-DESIGN AND METHODOLOGY OF THE

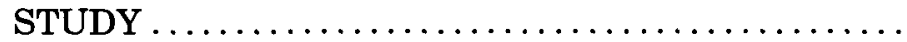

APPENDIX B-CHAPTER 13 PROJECT CODING

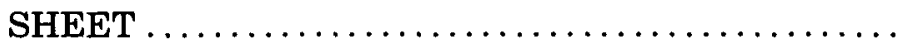

TABLE OF TABLES AND FIGURES $\ldots \ldots \ldots \ldots \ldots \ldots$

\section{INTRODUCTION}

There were nearly 1.6 million consumer bankruptcy filings in the United States in 2004. That is more than twice the number just ten years earlier ${ }^{1}$ and more than one filing for every seventy households in the country. ${ }^{2}$ Almost $29 \%$ of these filings - over 467,000 - were under Chapter 13 of the Bankruptcy Code. ${ }^{3}$ With the dramatic increases in consumer filings, even in prosperous economic times, there has been much debate about the causes of the "bankruptcy epidemic."4 The debate culminated last year in the enactment of extensive reform of United States consumer bankruptcy laws. The core of the legal reforms is a "means test" that is designed to limit consumer debtor access to Chapter 7, requiring some debtors to file for relief under Chapter 13 or not at all. Yet, little is known about what debtors and creditors accomplish in Chapter 13 cases or how well the Chapter 13 system serves its intended purposes. The government collects minimal information about consumer bankruptcy filings, and academic research has been limited.

The first national study of its kind, the Chapter 13 Project provides a detailed portrait of the Chapter 13 system and the extent to which Chapter 13 has fulfilled its principal purposes-debtor fresh

1. In 1994, there were 780,455 non-business filings. See Administrative Office of the U.S. Courts, 1983-2003 Bankruptcy Filings, 12-month period ending June, by Chapter and District [hereinafter 1983-2003 Bankruptcy Filings], at http://web.archives.org/ web/20040725085134/http://www.uscourts.gov/bnkrpctystats/1960-0312-MonthJune. pdf. Filings increased again, significantly, in 2005. Much or all of this increase is attributable to debtors filing in advance of the effective date of most of the provisions of the Bankruptcy Abuse Prevention and Consumer Protection Act of 2005 in October 2005.

2. As of March, 2003, there were 111 million households in the United States. Jason Fields, America's Families and Living Arrangements: 2003, CURRENT Population RePorTs (U.S. Census Bureau, Washington, D.C.), Nov. 2003, at 2, available at http:// www.census.gov/prod/2004pubs/p20-553.pdf.

3. See 1983-2003 Bankruptcy Filings, supra note 1.

4. See generally Personal Bankruptcy: A Literature Review, CBO PAPER (Congressional Budget Office), Sept. 2000, available at http://www.cbo.gov/showdoc.cfm?index= $2421 \&$ sequence $=0$ (reviewing the macro-economic literature relating to filing rates, factors leading to personal bankruptcy, the ability of Chapter 7 filers to repay their debts, and how personal bankruptcy affects the supply of credit; with bibliography of studies). 
start, on the one hand, and creditor repayment, on the other. In addition, the study explores an array of debtor characteristics, Chapter 13 plan features, and district and trustee practices for their relationship to debtor discharge and debt repayment in Chapter 13. Like several other studies before it, the Project also describes the debtors who have used Chapter 13.

\section{SUMMARY AND HIGHLIGHTS OF PROJECT FINDINGS}

\section{A. Debtor Discharge}

The overall discharge rate for the debtors in the seven districts covered by the Project was $33 \%$; $67 \%$ of cases were dismissed or converted, $23 \%$ before confirmation and $44 \%$ after confirmation. As a percentage of cases with a confirmed plan (excluding cases dismissed before confirmation), the discharge rate was nearly $43 \%$.

Discharge rates varied considerably across the seven districts in the sample, from a low of $27 \%$ (or $20 \%$ including cases dismissed before confirmation) in the Western District of Tennessee to a high of $54 \%$ (or $47 \%$ including cases dismissed before confirmation) in the Middle District of North Carolina. We expected, but did not find, that higher plan completion rates correlate with higher pre-confirmation dismissal rates. This and several other findings support the conclusion that some courts do not carefully screen cases for feasibility at confirmation. On the other hand, the data also reveal that apparent lack of feasibility is not significantly related to case outcome.

One of the more striking findings of the study is that at least $50 \%$ of the debtors filed one or more other bankruptcy cases, either before or after the sample case. Thirty percent (30\%) filed at least one other case, $10 \%$ filed at least two other cases, and $10 \%$ filed at least three or more other cases. There was a statistically significant relation between judicial district and incidence of other filings; about $20 \%$ of the debtors in the Middle District of North Carolina filed a later petition, while no less than $56 \%$ of the debtors in the Western District of Tennessee have filed more than one case, compared to the overall subsequent refiling rate of $33 \%$. The great majority of the other filings were also under Chapter 13, and most were made within a year of the filing in the sample case. Debtors who filed bankruptcy for the first time in the sample case were significantly more likely to complete their plans than debtors who had filed one or more previous cases. Thirty-eight percent $(38 \%)$ of first-time filers completed their plans compared to $22.5 \%$ who had filed one previous case. The discharge rate plummeted to $14 \%$ for debtors who had filed two or more cases before the sample case. 
Nearly one in seven (15\%) debtors who received a discharge went on to file another case.

Debtors in nearly $45 \%$ of the cases in which a proposed distribution was reported proposed to pay no more than $25 \%$ of unsecured claims. In $31 \%$ of cases the debtors proposed to pay $100 \%$. Relatively few debtors - less than $10 \%$-proposed to pay between $26 \%$ and $99 \%$. There was no significant difference in the proposed percentage to be paid on unsecured debt by debtors in completed cases and debtors in cases that were dismissed or converted.

Notably, a very large percentage of the debtors proposed plans longer than the minimum thirty-six months required by the Code; the median and modal lengths of the sample debtors' plans were sixty months, or twenty-four months longer than the standard set out in the Bankruptcy Code. Indeed, the length of plans at the 25th percentile was forty-seven months, or nearly a year longer than the standard envisioned by the Bankruptcy Code. However, debtors who proposed shorter plans were more likely to complete their plans.

Joint petitioners were significantly more likely to complete a plan than individual filers. The higher completion rate for joint filers could not be tied to the presence of a second income, however. Individual petitioners reporting spousal income did not complete their plans at a statistically significantly greater rate than individual filers who did not report a second income.

Debtors who completed their plans on average owed more total pre-bankruptcy debt and had higher debt-income ratios than debtors whose cases were dismissed or converted. Perhaps debtors who were more reluctant to file were more committed to doing what was necessary to complete a plan.

\section{B. Creditor Repayment}

The primary creditor beneficiaries by far of the Chapter 13 system are secured creditors. Nationally, the percentage of trustee disbursements to secured creditors ranged between $60 \%$ and $69 \%$ of total disbursements between 1994 and 2003. Yet, these percentages substantially understate the proportion of all payments by Chapter 13 debtors to secured creditors, because they do not include payments made directly by debtors to secured creditors, in particular mortgage creditors.

Less than a third of trustee disbursements were to general unsecured creditors.

Chapter 13 costs, which include debtor attorney's fees, clerk's noticing fees charged to the case, and any $\S 507$ (b) awards, were a sizable portion of total trustee distributions to creditors and equaled a 
very large percentage of disbursements to general unsecured creditors. The ratio of Chapter 13 costs to total trustee disbursements was quite stable over the years 1994 to 2003 , ranging from $15 \%$ to $18 \%$. The ratio of Chapter 13 costs to total trustee disbursements to general unsecured creditors ranged between $59 \%$ and $75 \%$; in other words, Chapter 13 costs equaled as much as $75 \%$ of disbursements to unsecured creditors.

Not surprisingly, creditor collections were greater in cases with a confirmed plan, and greater still in cases that proceeded to discharge of the debtor. Even so, debtors paid no more unsecured debt in cases dismissed before confirmation than in cases dismissed after confirmation.

\section{Profile of the Debtors}

The debtors in the Chapter 13 Project are very similar in terms of gender, debt-income ratio, and homeownership rates to debtors in previous studies. Most of the debtors in the Chapter 13 Project were far less affluent than the population as a whole. In 1994 dollars, only $25 \%$ earned more than $\$ 26,000$ per year. Half earned less than $\$ 18,000$ in annual gross income, and $25 \%$ earned less than $\$ 13,000$. The mean debtor household annual income was less than half the mean for all households; and the median was less than $60 \%$ of the median for all households in the country.

\section{The Bankruptcy Abuse Prevention and Consumer Protection ACt of 2005}

The Chapter 13 Project establishes a detailed picture of Chapter 13 outcomes that will serve as a baseline for measuring the muchcriticized changes in the law wrought by the Bankruptcy Abuse Prevention and Consumer Protection Act of 2005. The BAPCPA reforms are complex, and their effects on Chapter 13 outcomes for debtors and creditors are subject to considerable speculation. For example, the new provision limiting strip-down of certain purchase money security interests in Chapter $13^{5}$ might be expected to further increase the share of Chapter 13 disbursements paid to secured creditors and to correspondingly reduce payments to unsecured creditors. At the same time, this anti-lien stripping provision may lead some debtors who would otherwise file in Chapter 13 to file under Chapter 7 because they can not afford to pay $100 \%$ of the claim, ${ }^{6}$ also reducing collections

5. 11 U.S.C.A. § 1325(a) (2006).

6. Henry E. Hildebrand, III, Impact of the Bankruptcy Abuse Prevention and Consumer Protection Act of 2005 on Chapter 13 Trustees, 79 AM. BANKR. L.J. 373, 386 n.70 (2005) (referring to preliminary analysis by the National Association of Chapter 13 
by unsecured creditors. For debtors who are or would be means-tested out of Chapter 7, the means test will determine the amount of their "disposable income" that must be devoted to a Chapter 13 plan.7 Whether this test requires more or less in debtor plan payments than the current disposable income test remains to be seen. The new limitations on repeat filings may boost overall discharge rates and thus increase average creditor collections per case. The credit counseling and debtor education requirements also may have far-reaching consequences.

\section{DESIGN AND METHODOLOGY OF THE STUDY}

The Chapter 13 Project is an empirical study of 795 Chapter 13 cases filed in 1994 in seven federal judicial districts comprising fourteen Chapter 13 trusteeships. The seven federal judicial districts are Northern District of Georgia, Southern District of Georgia, Middle District of North Carolina, Middle District of Tennessee, Western District of Tennessee, District of Maryland, and Western District of Pennsylvania. Collectively, these seven districts accounted for a very large portion - nearly 20\%-of Chapter 13 filings nationally in 1994. There were 240,639 Chapter 13 filings in 1994, including 47,393 in the seven sample districts. ${ }^{8}$

In each district, we pulled a quota sample of one percent $(1 \%)$ of the Chapter 13 cases filed in 1994, but no fewer than 100 cases. The sample includes 165 cases from the Northern District of Georgia, 130 cases from the Western District of Tennessee, and 100 cases from each of the other five districts.

The Chapter 13 Project's sample of debtors, trusteeships, and districts is highly representative of the nation as a whole, notwithstanding that there are significant variations in practice among districts, judges, and trustees across the country. 9 The discharge rate for the

Trustees in 2001 that indicated $23 \%$ of Chapter 13 plans would not be confirmable if auto loans could not be stripped down).

7. 11 U.S.C.A. $\$ 1325$ (b)(3) (2006) (as amended by the BAPCPA).

8. See Administrative Office of the U.S. Courts, 1983-2003 Bankruptcy Filings, 12-month period ending June, by Chapter and District Thereinafter 1983-2003 Bankruptcy Filings], at http://web.archives.org/web/20040725085134/http://www.uscourts. gov/bnkrpetystats/1960-0312-MonthJune.pdf.

9. The study of the bankruptcy system in the United States poses some difficult challenges in that, while one Code and one set of Rules of Procedure govern all cases in all bankruptcy courts, there are wide variations in the local practices and attitudes of bankruptcy trustees, lawyers, and judges. Sometimes referred to as "local legal culture," these variations often are large and contribute substantially to case outcomes for debtors and creditors alike. See Jean Braucher, Lawyers and Consumer Bankruptcy: One Code, Many Cultures, 67 Am. BANkR. L.J. 501 (1993); Teresa A. Sullivan, Elizabeth Warren \& Jay L. Westbrook, The Persistence of Local Legal Culture: Twenty Years of Evidence from the Federal Bankruptcy Courts, 17 Harv. J.L. \& PUB. POL'Y 801 (1994); 
795 debtors, as well as the average discharge rate across the seven districts, was almost identical to the oft-cited national average of $33 \% .{ }^{10}$ Further, the amounts and types of debt repaid by the debtors were similar to the national averages reported by the Executive Office for United States Trustees for all Chapter 13 cases closed during the same time period. ${ }^{11}$ The percentages of male and female petitioners and the debt-income ratios of the debtors were comparable to those observed in other studies. ${ }^{12}$

While representative of the nation in the key areas of debtor discharge and creditor repayment, the sample is, of course, not a national sample. The sample districts are located mostly in Southern states with higher Chapter 13 filing rates. At the same time, the choice of seven districts that accounted for nearly $20 \%$ of all Chapter 13 filings likely contributed to, rather than detracted from, the representativeness of the sample. The representativeness of the sample also was not undermined by the fact that it includes one percent of 1994 filings in the NDGA and WDTN and more than one percent of filings in the other five districts (ranging from 1.9\% of Chapter 13 filings in the SDGA in 1994 to $11.9 \%$ in the WDPA). ${ }^{13}$ Further, by including a minimum of 100 cases from each district, we were able to run several inter-district analyses and intra-district comparisons.

We use the term "significant" throughout the paper to mean statistical significance. Statistical analyses were performed using the SPSS software package. We used a criterion level of $5 \%$; thus, statistical significance is inferred only when there would be a $5 \%$ or less probability that a finding arose by chance. Most of the time, we used chi-square tests for comparisons of nominal and ordinal variables (e.g., district, case disposition, other filings) and t-tests for comparisons of interval variables (e.g., income, debt). The statistical analyses do not interpolate or extrapolate the values of missing data. If data

William C. Whitford, Has the Time Come to Repeal Chapter 13?, 65 IND. L.J. 85 (1989); Teresa A. Sullivan, Elizabeth Warren \& Jay L. Westbrook, Laws, Models, and Real People: Choice of Chapter in Personal Bankruptcy, 13 LAW \& Soc. InquiRY 661, 693-700 (1988).

10. See infra notes 70-72 and accompanying text and Tables 18 and 19.

11. See infra notes $\mathbf{1 8 2 - 8 8}$ and accompanying text and Tables 43 and 44 (demonstrating that while the sample debtors repaid somewhat more secured debt than the estimated national average, the difference was well within the standard deviation for the sample). In addition, the ratio of trustee disbursements to secured, priority, and unsecured creditors, the increases in disbursements over the period 1994-2003, and the ratios of Chapter 13 costs to total creditor and to unsecured creditor disbursements in the sample districts are very closely comparable to the national figures. See id.

12. See infra notes 20-21 and accompanying text and Table 1 .

13. Arguably, the statistical analyses of data on all debtors should be performed on the same percentage of cases from each district, in order to assure that district- or trustee-based variations in the data do not disproportionately impact the national picture created by the data set. 
were not available, the case was excluded from the relevant analysis. Much of the data analyzed for the study did not meet the criteria to be considered normally distributed in the sample; when normality assumptions were substantially violated and could not easily be resolved by excluding outlying scores ( $+3 S D$ 's above the mean), non-parametric statistical analyses were used in order to maintain a Type I error rate of less than .05 .

At several points in the paper, we compare financial data (e.g., debtor income, average disbursements per case) for one year with data for another year. In doing so, we adjusted the dollar amounts using the commonly used Consumer Price Index.

By way of caveat, there are several limitations inherent in the data with respect to (a) the amounts of long-term secured debt - usually, mortgage debt - owed by the debtors, and (b) the amounts of such debt repaid by the debtors. Long-term mortgage debts normally entail two components in Chapter 13 cases: first, a claim for pre-petition arrearages, invariably reported as a separate claim, which was to be paid under the plan; and second, a claim for the balance of the mortgage loan, as to which the debtor was to make the regular monthly payments due after filing. Then, as now, districts and trustees followed either of two different practices regarding post filing mortgage payments. In some districts, debtors ordinarily make post filing mortgage payments through the plan, while in other districts they typically make these payments directly to the mortgagee. ${ }^{14}$ In the former districts, the payments to secured creditors reported by the trustees naturally were much, much larger than those reported in the other districts, although the debtors in both districts made postpetition mortgage payments. As to this problem, it simply was not possible to ascertain how much debtors might have paid to mortgagees outside a plan, nor was it possible to separate mortgage payments made under a plan from other secured debt payments made under the plan. Thus, the Project data understate debtor payments to secured creditors, because they include ongoing mortgage payments for some debtors (those in districts in which these payments were made through the

14. See Gordon Bermant \& Ed Flynn, Bankruptcy by the Numbers, Chapter 13: Who Pays the Mortgage?, 20 AM. BANKR. INST. J. 20, 20 (June 2001) (reporting that "in 1999 one-third (58/175) of the standing trustees were making ongoing mortgage payments for at least some of their cases"). See also Gordon Bermant, Making Post-Petition Mortgage Payments Through the Plan: A Survey of Standing Chapter 13 Trustees, A First Draft Report of Survey Results to the Endowment Committee of the National Conference of Bankruptcy Judges (July 2004) (manuscript on file with the author) (reporting on survey of standing Chapter 13 trustees regarding practices respecting payment of mortgages under the plan). In his survey of Chapter 13 trustees who make postpetition mortgage payments through the plan, Dr. Bermant found that about half do so only when the debtors owe mortgage arrearages. $I d$. at 16. 
plan), but not for others (those in districts in which these payments normally were not made under the plan).

Also problematic in some trusteeships or cases, long-term mortgage (non-arrearage) claims may have been included in the trustee's record of secured claims against the debtor, while in other trusteeships or cases these claims were not listed. If included, the debtor's secured and total indebtedness obviously would appear much larger than if these claims are not included. As to this problem, we achieved consistency by excluding long-term mortgage debts from our calculations; the data we report on allowed claims and debtor indebtedness, ${ }^{15}$ debt-income ratios, ${ }^{16}$ relationship between debt-income ratio and case outcome, ${ }^{17}$ and relationship between creditor claims and case outcome $^{18}$ exclude long-term mortgage debts as best we were able. ${ }^{19}$ As a result, however, the data understate the debtors' secured debt, total indebtedness, and debt-income ratios to the extent of any long-term mortgage debt.

In all districts and trusteeships, mortgage arrearage claims were reflected in the trustee records, and further, were almost invariably paid under, not outside, the plan. The data that we report regarding amounts of secured and total indebtedness and debt-income ratios includes mortgage arrearages; and the data that we report on debt repayment includes plan payments on mortgage arrearages.

Additional details regarding the design and methodology of the study are included in Appendix A, Design and Methodology of the Study, and Appendix B, the Chapter 13 Project Coding Sheet.

\section{PROFILE OF CHAPTER 13 DEBTORS}

As a preface to the following Parts V and VI regarding debtor discharge and creditor repayment in Chapter 13, this Part IV sketches a limited profile of the debtors in the study sample based on information available from the Chapter 13 trustee reports, bankruptcy court case files, and PACER. In particular, this Part reports on the gender and household size, income, indebtedness, debt to income ratio, home-

15. See infra notes 39-41 and accompanying text and Table 8 .

16. See infra notes $42-47$ and accompanying text and Table 9 .

17. See infra notes 95-105 and accompanying text and Table 27.

18. See infra notes 89-92 and accompanying text and Table 26.

19. A few long-term mortgage debts may not have been excluded; the Chapter 13 trustee case data may not always have correctly typed a mortgage claim as a mortgage claim. There are a few cases in which the debtors owed secured debts greater than $\$ 50,000$, but the trustee claim record did not identify it as a mortgage debt. It seems likely that some of these claims were mortgage claims, but we did not exclude them as they were not identified as mortgage claims. The number of these claims is so small that their inclusion would not materially affect the analyses. 
owner status, and previous and subsequent bankruptcy filings of the 795 debtors in the study sample.

\section{A. Gender and Household Size of Petitioners}

\section{Gender}

The petitioners were almost exactly evenly divided between men and women. ${ }^{20}$ As reported in Table 1, women constituted $36.3 \%$ of the petitioners, and men constituted $36.9 \%$. The balance was joint petitioners. Other recent studies likewise have found that about 35-40\% of bankruptcy petitioners were women filing singly. ${ }^{21}$

\section{TABLE 1. GENDER OF PETITIONERS}

\begin{tabular}{|l|c|c|}
\hline Gender & Number & Percent of all Petitioners \\
\hline Female & 273 & $36.3 \%$ \\
\hline Male & 277 & $38.7 \%$ \\
\hline Joint & 203 & $27.0 \%$ \\
\hline Total & $753\left(42\right.$ missing $\left.^{22}\right)$ & $100.00 \%$ \\
\hline
\end{tabular}

20. The form petition, Schedules, and Statement of Financial Affairs do not ask the debtor to indicate gender (or race). See Official Bankruptcy Forms 1, 6 \& 7. Gender must be inferred from the debtor's first name. It was not possible to make even an educated guess about a debtor's gender in only eighteen cases.

21. The percentage as well as absolute numbers of women filing for bankruptcy relief have increased over time. See Elizabeth Warren, What Is a Women's Issue? Bankruptcy, Commercial Law, and Other Gender-Neutral Topics, 25 HaRv. Women's L.J. 19, 24, $27 \mathrm{n} .40$ (2002) (reporting findings of 2001 study of Chapter 7 and Chapter 13 debtors in five judicial districts; $39 \%$ of petitions were by women filing alone, $28.8 \%$ by men filing alone, and $32.0 \%$ by husband and wife filing jointly); Teresa Sullivan, Elizabetr Warren \& Jay L. Westbrook, The Fragile Middle Class, Americans in Debt 36-37 (2002) (study of debtors in sixteen judicial districts who filed for bankruptcy under Chapter 7 or Chapter 13 in 1991; finding that $30 \%$ of petitions were filed by women, $26 \%$ were filed by men, and $44 \%$ were joint petitions and reporting that the proportion of petitions filed by women, by men, and jointly was about the same in Chapter 13 and Chapter 7 cases); Teresa Sullivan \& Elizabeth Warren, The Changing Demographics of Bankruptcy, NoRTON BANKR. L. ADVISOR 1-7 (Oct. 1999) (also reporting results of study of chapter 7 and chapter 13 cases in 2001, finding nearly $39 \%$ of filings were by women, $33 \%$ joint, and $29 \%$ by men); Ed Flynn \& Gordon Bermant, Bankruptcy by the Numbers, Demographics of Chapter 7 Debtors, 18 AM. BANKR. INsT. J. 24 (Sept. 1999) (reporting on survey by Executive Office for United States Trustees of 1452 no-asset chapter 7 cases filed in late 1998 or early 1999 and finding that $34.6 \%$ of cases were filed by women, $29.5 \%$ by men, and $35 \%$ by joint petitioners); Teresa A. Sullivan, Elizabeth WarRen \& Jay L. Westbrook, Bankruptcy and the Family, Families and LaW 193, 207 (Lisa J. McIntyre \& Marvin B. Sussman eds., The Haworth Press, Inc., 1995) (also reporting on the 1991 study of debtors in the Consumer Bankruptcy Project).

22. Includes eighteen cases in which the gender of the petitioner is undetermined, including one case for which filing status (joint or individual) is unknown. 


\section{Household Size}

Table 2 reports that the average household size of the debtors in the sample was 2.69. Household size is the sum of the petitioner(s) and any dependents. Dependents include any children in a joint filing, and any spouse or child in a single filing. The median household size was 2. For joint petitioners, the mean and median were significantly higher than for all debtors, 3.61 and 4, respectively. Female petitioners' households were slightly larger on average than male petitioners', 2.39 compared to 2.32 .

TABLE 2. HOUSEHOLD SIZE OF PETITIONERS BY GENDER

\begin{tabular}{|l|c|c|c|c|c|c|c|c|}
\hline $\begin{array}{l}\text { Petitioner } \\
\text { Gender }\end{array}$ & $\mathrm{N}$ & Range & Mean & SD & SEM & $25 \%$ & Median & $75 \%$ \\
\hline Female & 273 & $1-7$ & 2.39 & 1.32 & 0.08 & 1 & 2 & 3 \\
\hline Male & 277 & $1-11$ & 2.32 & 1.55 & 0.093 & 1 & 2 & 3 \\
\hline Joint & 203 & $1-8$ & 3.61 & 1.34 & 0.094 & 2 & 4 & 4 \\
\hline All 23 & 770 & $1-11$ & 2.69 & 1.52 & 0.055 & 1 & 2 & 4 \\
\hline missing & 25 & & & & & & & \\
\hline
\end{tabular}

Table 3 reports the frequency of occurrence of each household size between 1 and 11 of the cases in the sample. Just over one quarter of all households were composed of only the debtor, while nearly another quarter were composed of two persons. Approximately 37\% of households were composed of three or four persons, including the debtor. Only $12.2 \%$ of the households were composed of more than four persons.

TABLE 3. HOUSEHOLD SIZE OF PETITIONERS (FREQUENCY)

\begin{tabular}{|l|l|c|}
\hline Household Size & Number & Percent \\
\hline 1 & 198 & $25.9 \%$ \\
\hline 2 & 188 & $24.6 \%$ \\
\hline 3 & 161 & $21.0 \%$ \\
\hline 4 & 124 & $16.2 \%$ \\
\hline 5 & 62 & $8.1 \%$ \\
\hline $6-11$ & 32 & $4.2 \%$ \\
\hline total & 765 (30 missing) & $100 \%$ \\
\hline
\end{tabular}

23. Includes seventeen cases in which the gender of the petitioner is undetermined, while excluding twenty-five cases in which data on household size is missing. 


\section{Number of Dependents}

As to be expected, the data on number of dependants closely parallel the data on household size. Table 4 reports that the mean number of dependents was 1.25 . The mean for joint petitioners, 1.65 , was significantly higher than for male and female petitioners filing individually ( 0.99 and 1.2 , respectively). The mean for female petitioners was somewhat higher than for male petitioners, 1.2 versus 0.99 . These latter figures probably obscure, however, that there are more children in cases filed by women individually than in cases filed by men individually, ${ }^{24}$ but our data on the point are not complete.

\section{TABLE 4. NUMBER OF DEPENDENTS BY GENDER}

\begin{tabular}{|l|c|c|c|c|c|c|c|c|}
\hline $\begin{array}{l}\text { Petitioner } \\
\text { Gender }\end{array}$ & $\mathrm{N}$ & Range & Mean & SD & SEM & $25 \%$ & Median & $75 \%$ \\
\hline Female & 273 & $0-6$ & 1.2 & 1.23 & 0.074 & 0 & 1 & 2 \\
\hline Male & 276 & $0-9$ & 0.99 & 1.3 & 0.078 & 0 & 1 & 2 \\
\hline Joint & 203 & $0-6$ & 1.65 & 1.31 & 0.092 & 0 & 2 & 2 \\
\hline $\begin{array}{l}\text { All (incl. } \\
\text { "unsure") }\end{array}$ & 770 & $0-9$ & 1.25 & 1.3 & 0.047 & 0 & 1 & 2 \\
\hline missing & 25 & & & & & & & \\
\hline
\end{tabular}

Table 5 reports the frequency of occurrence of each number of dependents from one to nine. Nearly $38 \%$ of filers had no dependents. Eighty-four percent of households included two or fewer dependents, while only $16 \%$ had three or more.

\section{TABLE 5. NUMBER OF DEPENDENTS PER HOUSEHOLD (FREQUENCY)}

\begin{tabular}{|l|l|c|}
\hline Number of Dependents & \multicolumn{1}{|c|}{ N } & Percent \\
\hline 0 & 289 & $37.8 \%$ \\
\hline 1 & 175 & $22.9 \%$ \\
\hline 2 & 179 & $23.4 \%$ \\
\hline 3 & 82 & $10.7 \%$ \\
\hline 4 & 25 & $3.3 \%$ \\
\hline $5-9$ & 15 & $2.0 \%$ \\
\hline Total & 765 (30 missing cases) & $100 \%$ \\
\hline
\end{tabular}

24. See Elizabeth Warren, Bankrupt Children, 86 MinN. L. REv. 1003 (2002) (reporting findings from Phase III of the Consumer Bankruptcy Project, an empirical study of 1250 cases in five judicial districts, that bankruptcy filing rates for unmarried women are much higher than for married couples or for unmarried men). 


\section{B. INCOME AND INDEBTEDNESS}

\section{Debtor and Household Income}

Table 6 reports on debtor and household, annual gross and net incomes, in 1994 dollars, as of the time of Chapter 13 filing. ${ }^{25}$ The mean and median annual gross incomes of the individual debtors in the sample were $\$ 20,578$ and $\$ 18,396$, respectively, and their mean and median annual net incomes were $\$ 16,824$ and $\$ 15,180$. The mean and median annual gross incomes of the debtor households were $\$ 25,274$ and $\$ 22,314$, respectively, while the mean and median annual net incomes of the debtor households were $\$ 20,571$ and $\$ 18,246 .{ }^{26}$ That the means are somewhat greater than the medians indicates that some debtors and households had relatively higher incomes that increased the overall means. The standard deviation ${ }^{27}$ of the debtors' annual gross incomes, $\$ 11,205$, is moderate - approximately one-half the mean - indicating a moderately wide variation in debtor gross incomes. For household annual gross income, the standard deviation, $\$ 13,816$, also is moderate - again, nearly half the mean - again indicating a moderately wide variation in debtor household incomes. The standard error of the mean (SEM ${ }^{28}$ ) indicates that the true mean debtor annual gross income in the population was between $\$ 10,409$

25. These data were obtained from Schedule I ("Current Income of Individual Debtors") of the debtors' Schedules of Assets and Liabilities. See Form 6, Official Bankruptcy Forms. Schedule I requires the debtor to state the debtor's monthly gross income and payroll deductions and state the debtor's spouse's monthly gross income and payroll deductions, if the debtor is married, regardless of whether the petition was a joint petition with the spouse. Thus, as used here, net income refers to gross income minus payroll deductions; and household income refers to the combined incomes of the debtor and any spouse.

26. The median and mean gross incomes of the debtors in the Chapter 13 Project were remarkably similar to, albeit slightly more than, those of the debtors studied by Sullivan, Warren, and Westbrook ("SWW") in The Fragile Middle Class, supra note 21 \& Table 2.3. The Fragile Middle Class studied debtors in sixteen judicial districts who filed for bankruptcy under Chapter 7 or Chapter 13 in 1991. The median and mean incomes of the debtor households, in 1994 dollars, adjusted for comparison to the Chapter 13 Project sample, were $\$ 19,542$ and $\$ 22,099$, respectively, compared to $\$ 22,314$ and $\$ 25,274$ for the debtors in the Chapter 13 Project. The SWW figures include both Chapter 7 and Chapter 13 filers. Because Chapter 13 debtors have higher average incomes than Chapter 7 debtors, it is expected that the figures for Chapter 13 debtors in the Chapter 13 Project would be somewhat higher.

27. The standard deviation is a measure of variability within the sample. In a statistically normal distribution, $68 \%$ of all scores are within one standard deviation of the mean, however, the debtor and household incomes are not normally distributed in the Project sample.

28. The standard error of the mean (SEM) is a measure of the reliability of the sample mean's ability to estimate the "true mean" of the population. The range within which the true mean of the population falls, at a $95 \%$ level of confidence, is the mean of the sample, plus or minus 1.96 times the SEM. 
and $\$ 12,001$. As to mean household annual gross income, the confidence interval of the estimate of mean is $\$ 12,830-\$ 14,802.29$

The 25th and 75th percentile amounts provide further insight into the diversity among debtors with respect to personal and household, annual gross and net incomes. Twenty-five percent $(25 \%)$ of debtors had annual gross income below $\$ 13,110$ and annual net income below $\$ 11,040$. Twenty-five percent had annual gross income above $\$ 26,220$ and annual net income above only $\$ 21,192$. The household annual gross income figures are very similar to the debtor annual gross income numbers at the 25th and 75th percentiles: $25 \%$ of households had annual gross income below $\$ 13,077$ and $25 \%$ had more than $\$ 26,436$.

The debtor households in the study sample were markedly less affluent than the U.S. population as a whole. In 1994, the mean and median household incomes in the United States were $\$ 50,961$ and $\$ 38,119$, respectively, ${ }^{30}$ compared to $\$ 25,274$ and $\$ 22,314$ for the debtor households. That is, the mean debtor household annual income was less than half the mean for all households; and the median was less than $60 \%$ of that for all households.

29. Naturally, debtor and household annual net incomes were much less than the gross. As reported in Table 5, the mean and median debtor annual net incomes were $\$ 16,824$ and $\$ 15,180$, respectively, or $18.3 \%$ and $17.5 \%$, respectively, less than the mean and median debtor annual gross incomes. Likewise, the mean and median debtor household annual net incomes were $\$ 20,571$ and $\$ 18,246$, respectively, or $18.7 \%$ and $18.2 \%$, respectively, less than the mean and median household gross incomes.

30. See, e.g., Carmen DeNavas-Walt \& Robert W. Cleveland, Money Income in the United States: 2001, Current Population Reports, Consumer Income (U.S. Census Bureau, Washington, D.C.), Sept. 2002, at 21, Appendix A, Table A-1, available at http:/ /www.census.gov/prod/2002pubs/p60-218.pdf. 


\section{TABLE 6. DEBTOR AND HOUSEHOLD, ANNUAL GROSS AND NET INCOME}

\begin{tabular}{|l|c|c|c|c|c|c|c|c|}
\hline & $\mathrm{N}$ & Range & Mean & SD & SEM & $25 \%$ & Median & $75 \%$ \\
\hline $\begin{array}{l}\text { Debtor Annual } \\
\text { Gross Income }\end{array}$ & 761 & $\$ 0-\$ 66,393^{31}$ & $\$ 20,578$ & $\$ 11,205$ & $\$ 406$ & $\$ 13,110$ & $\$ 18,396$ & $\$ 26,220$ \\
\hline $\begin{array}{l}\text { Debtor Annual } \\
\text { Net Income }\end{array}$ & 763 & $\$ 0-\$ 56,400^{32}$ & $\$ 16,824$ & $\$ 8,657$ & $\$ 313$ & $\$ 11,040$ & $\$ 15,180$ & $\$ 21,192$ \\
\hline $\begin{array}{l}\text { Household Annual } \\
\text { Gross Income }\end{array}$ & 754 & $\$ 0-\$ 78,324$ & $\$ 25,274$ & $\$ 13,816$ & $\$ 503$ & $\$ 14,991$ & $\$ 22,314$ & $\$ 32,523$ \\
\hline $\begin{array}{l}\text { Household Annual } \\
\text { Net Income }\end{array}$ & 754 & $\$ 0-\$ 65,100^{34}$ & $\$ 20,571$ & $\$ 10,502$ & $\$ 382$ & $\$ 13,077$ & $\$ 18,246$ & $\$ 26,436$ \\
\hline
\end{tabular}

\section{Income and Gender}

The data reveal statistically significant differences in income based on the debtor's gender. As shown in Table 7 below, female petitioners reported significantly less annual income than either male or joint petitioners. Male petitioners reported the highest incomes. $\mathrm{Fe}$ male petitioners reported mean and median annual income of $\$ 15,060$ and $\$ 14,220$, respectively, compared to $\$ 16,848$ and $\$ 15,516$ for joint petitioners, and $\$ 18,461$ and $\$ 16,848$ for male petitioners. While the proximity of the mean and median values within each of the three groups indicates fairly symmetrical distributions in the trimmed data, the amount of variance within each group was still substantial. ${ }^{35}$

31. All income amounts $>\$ 66,393(M+3.0 S D)$ were excluded from descriptive procedures.

32. All income amounts $>\$ 56,400(M+3.0 S D)$ were excluded from descriptive and inferential procedures.

33. All income amounts $>\$ 78,324(M+3.0 S D)$ were excluded from descriptive and inferential procedures.

34. All income amounts $>\$ 65,100(M+3.0 S D)$ were excluded from descriptive and inferential procedures.

35. A small number of cases $(n<40)$ reported gross and net incomes that were substantially greater than the mean of their respective samples. The cases that were more than three standard deviations above their respective sample means were excluded from further analyses. A Kruskal-Wallis, non-parametric analysis indicated that female petitioners reported significantly lower annual income than the overall sample median annual income, $\Pi^{2}(2, N=754)=16.74, p \# .001$; and that female petitioners reported significantly lower annual household income than the overall sample median annual household income, $\Pi^{2}(2, N=749)=83.1, p \# .001$. 
TABLE 7. ANNUAL GROSS INCOME BY GENDER OF PETITIONER

\begin{tabular}{|l|c|c|c|c|c|c|c|c|}
\hline $\begin{array}{l}\text { Gender of } \\
\text { Petitioner }\end{array}$ & $\mathrm{N}$ & Range & Mean & SD & SEM & $25 \%$ & Median & $75 \%$ \\
\hline Female & 271 & $\$ 0-\$ 48,204^{36}$ & $\$ 15,060$ & $\$ 7,476$ & $\$ 454$ & $\$ 10,308$ & $\$ 14,220$ & $\$ 18,528$ \\
\hline Joint & 199 & $\$ 0-\$ 52,248^{37}$ & $\$ 16,848$ & $\$ 8,485$ & $\$ 602$ & $\$ 11,328$ & $\$ 15,516$ & $\$ 21,168$ \\
\hline Male & 276 & $\$ 0-\$ 66,060^{38}$ & $\$ 18,461$ & $\$ 9,259$ & $\$ 557$ & $\$ 11,616$ & $\$ 16,848$ & $\$ 23,724$ \\
\hline
\end{tabular}

\section{Debtor Indebtedness}

Table 8 below reports the range, mean, median, and 10th, 25th, 75th, and 90th percentile amounts of the allowed secured, priority, general, and total claims against the debtors in the study sample in 1994 dollars. The figures for secured claims do not include post filing mortgage debts, but do include pre-filing mortgage arrearage claims. ${ }^{39}$

For each type of debt, and total debt, the mean substantially exceeds the median, indicating that a relatively few cases with relatively large claims increased the overall debtor averages. The standard deviations likewise indicate a very wide spread in the amount of debt carried by the debtors in the sample cases.

The mean total debt (excluding post filing mortgage balances) was over $\$ 24,000$, while the median amount was nearly $\$ 16,000$ and the standard deviation was $\$ 32,755$. The median and 10th, 25th, 75th, and 90th percentile amounts of total debt further illustrate the spread among debtors in total debt, with a positive skew to the distribution. The figures for standard error of the mean indicate a high level of confidence that the mean debt amounts in the sample approximate the mean debt amounts in the entire population of debtors.

For most debtors, most allowed debt was secured debt. The mean amount of secured debt (excluding non-arrearage mortgage claims) was $\$ 11,593$, with a median of $\$ 7,178$ and a standard deviation of $\$ 20,395$.

36. All income amounts $>\$ 48,204(M+3.0 S D)$ were excluded from descriptive and inferential procedures.

37. All income amounts $>\$ 52,248(M+3.0 S D)$ were excluded from descriptive and inferential procedures.

38. All income amounts $>\$ 66,060(M+3.0 S D)$ were excluded from descriptive and inferential procedures.

39. As discussed above, supra notes 14-19 and accompanying text, some trustees include non-arrearage mortgage debts in their record of creditor claims, while others do not. Thus, in order to achieve consistency in the computation of allowed secured claims across trusteeships and debtors, we excluded long-term mortgage claims in calculating the amount of secured debt for all debtors. 
The distribution of priority debt was highly skewed. Most debtors had no priority debt, while a few owed very large priority debts. The mean was $\$ 1,857$, while the 10 th percentile, 25 th percentile, and median amounts of priority debt were $\$ 0$. The 75 th percentile amount was only $\$ 925$. The 90 th percentile was $\$ 3,823$, confirming that a very few debtors owed very large amounts of priority debt.

Table 8 is most reliable as to the debtors' general unsecured indebtedness. The mean amount of allowed unsecured debt was $\$ 9,958$, and the median was $\$ 5,143$, indicating that some debtors owed much more unsecured debt than most. ${ }^{40}$ The standard deviation for unsecured debt was very large, more than two times the mean, confirming the very large spread among debtors in amounts of unsecured indebtedness.

\section{TABLE 8. DEBTOR INDEBTEDNESS-ALLOWED CLAIMS ${ }^{41}$}

\begin{tabular}{|l|c|c|c|c|c|c|c|c|c|c|c|}
\hline $\begin{array}{l}\text { Allowed } \\
\text { Claims }\end{array}$ & $\mathrm{N}$ & $\begin{array}{c}\text { \# cases } \\
\text { vith } \\
\text { value } \\
\mathbf{\$ 0}\end{array}$ & Range & Mean & SD & SEM & $10 \%$ & $25 \%$ & Median & $75 \%$ & $90 \%$ \\
\hline Secured & $\begin{array}{c}787(8 \\
\text { missing) }\end{array}$ & $\begin{array}{c}121 \\
(15 \%)\end{array}$ & $\begin{array}{c}\$ 0- \\
\$ 376577\end{array}$ & $\$ 11,593$ & $\$ 20,395$ & 727 & $\$ 0$ & $\$ 1,707$ & $\$ 7,178$ & $\$ 14,733$ & $\$ 26,040$ \\
\hline Priority & $\begin{array}{c}783(12 \\
\text { missing) }\end{array}$ & $\begin{array}{c}462 \\
(59 \%)\end{array}$ & $\begin{array}{c}\$ 0- \\
\$ 115406\end{array}$ & $\$ 1,857$ & $\$ 7,124$ & 254.58 & $\$ 0$ & $\$ 0$ & $\$ 0$ & $\$ 925$ & $\$ 3,823$ \\
\hline General & $\begin{array}{c}782(13 \\
\text { missing) }\end{array}$ & $\begin{array}{c}86 \\
(11 \%)\end{array}$ & $\begin{array}{c}\$ 0- \\
\$ 257377\end{array}$ & $\$ 9,958$ & $\$ 19,976$ & 714.34 & $\$ 0$ & $\$ 1,364$ & $\$ 5,143$ & $\$ 10,615$ & $\$ 20,953$ \\
\hline Total & $\begin{array}{c}772(23 \\
\text { missing) }\end{array}$ & $\begin{array}{c}33 \\
(4 \%)\end{array}$ & $\begin{array}{c}\$ 0- \\
\$ 432084\end{array}$ & $\$ 24,294$ & $\$ 32,755$ & 1178.86 & $\$ 2,849$ & $\$ 8,112$ & $\$ 15,865$ & $\$ 28,914$ & $\$ 51,059$ \\
\hline
\end{tabular}

40. The Project did not investigate what types of debt composed the debtors' unsecured indebtedness. Professor Melissa Jacoby reports that $48.3 \%$ of Chapter 13 cases in an eight-judicial-district study of debtors who filed for bankruptcy in 1999 were "medical-related," that is, the debtors had at least $\$ 1000$ in health-related bills and/or reported illness or injury as a cause of their filing. Melissa Jacoby, Collecting Debts from the Ill and Injured: The Rhetorical Significance, but Practical Irrelevance, of Culpability and Ability to Pay, 51 AM. U. L. REv. 229 (2001). See also David U. Himmelstein, Elizabeth Warren, Deborah Thorne \& Steffie Woolhandler, Illness and Injury As Contributors to Bankruptcy, HeALTH AFF. (Feb. 2, 2005), at http://content.healthaffairs. org/cgi/reprint/hlthaff.w5.63v1.pdf (regarding same eight-judicial-district study, reporting that $46.2 \%$ of Chapter 7 and Chapter 13 cases were medical-related); Melissa B. Jacoby, Teresa A. Sullivan \& Elizabeth Warren, Rethinking the Debates over Health Care Financing: Evidence from the Bankruptcy Courts, 76 N.Y.U. L. REv. 375, 389-90 (2001) (same); Melissa B. Jacoby, Teresa A. Sullivan \& Elizabeth Warren, Medical Problems and Bankruptcy Filings, NorTON BANKR. L. ADVISOR, 4, Figure 2 (2000) (same study, finding $45.6 \%$ of debtors had either medical reason for filing or substantial medical debt).

41. This Table includes "other claims" in Total Allowed Claims, but does not separately report such claims because fewer than $10 \%$ of the cases included "other claims," and different trustees classified different sorts of claims as "other claims."

As indicated in the bottom row of this Table, there were thirty-three cases in which there were no allowed claims. Most or all of these cases were cases in which there were scheduled claims, but no allowed claims. All but six of the thirty-three cases were dismissed before confirmation. If only cases with confirmed plans are considered in computing allowed claims, the means change minimally and are well within the 


\section{Debt-Income Ratio}

Debt-to-income ratio is a primary measure of debtor financial distress; the higher the ratio, the more burdened was the debtor with debt and less able to pay that debt from current income. ${ }^{42}$ As reported in Table 9 below, the mean debt-annual net income ratio of the debtors in the study, excluding long-term mortgage debt, was 1.29.43 That is, the average debtor would have to devote all income for a period of more than 15 months to pay short-term debt, without reserving any income for payment of long-term mortgage debt or other living expenses such as rent, food, health care, transportation, and utilities. The median ratio was 0.965 , indicating that one half of the debtors had debts greater than nearly one year's net income, while one half had debts of less than one year's net income; and that a relatively few debtors with very high debt-income ratios pulled up the overall mean amount.

The 75th percentile debt-to-annual income ratio was 1.699 , indicating a sizable group of debtors with huge debt burdens. At the other end, the 25 th percentile debt-income ratio was $0.558 ; 25 \%$ of the debtors had somewhat less than twice as much annual net income as nonmortgage debt. However, these debtors' financial distress is greater than appears from the debt-income ratio. The debtors in this group tended to have more dependents and more people living in the household and lower incomes than the other debtors in the sample. Of 181 cases in the 25 th percentile, $40 \%$ had two or more dependents, and $35 \%$ had four or more people living in the household. These cases represent $83 \%$ of the 218 cases in the overall sample with four or more people in the household. Additionally, $45 \%$ of these cases were by wo-

margins of error of the means reported in the Table. Excluding cases dismissed or converted before confirmation of a plan, the mean secured debt was $\$ 11,257$, the mean priority debt was $\$ 1,514$, the mean unsecured debt was $\$ 10,636$, and the mean total debt was $\$ 24,381$.

42. Of course, debt-income ratio is not always an accurate indicator of financial distress; it does not account for assets and savings, which also may be used to pay debt. While acknowledging that debt-income ratios historically have closely paralleled consumer bankruptcy filing rates, Professor Todd Zywicki has argued that this "purported measurement [of debtor financial distress] is illogical" because debtors owe a mix of debts, some of which are to be paid over extended periods of time. He maintains that the better measure of debtor financial distress is "equity insolvency," which is a debtor's ability to pay debts as they come due. See Todd Zywicki, Why So Many Bankruptcies and What to Do About It: An Economic Analysis of Consumer Bankruptcy Law and Bankruptcy Reform, George Mason Law \& Economics Research Paper No. 03-46, 1625, 65 (2003), available at $\mathrm{http} / /$ papers.ssrn.com/sol3/papers.cfm?abstract_id=454121.

43. $(\mathrm{SEM}=.041)$. The figures are based on allowed claims and therefore may slightly understate the extent of debtor obligation because not all creditors file their claims. On the other hand, the trustee claims information did not always specify whether a secured claim was secured by a mortgage, automobile, or other collateral, thus a few mortgage claims likely are included in the figures. See supra note 19. 
men filing singly, compared to $36.3 \%$ in the overall sample of the study; and only $8 \%$ of these cases were joint filings, compared to $27 \%$ in the overall sample. The median gross annual household income for these cases was $\$ 20,796$, and the median net annual household income was $\$ 17,160$. These figures compare to the weighted-average poverty level for a household of four in 1994 of $\$ 15,141 ; 44$ in other words, most of these cases with lower debt-annual net income ratios were near or below the poverty level. ${ }^{45}$

The debt-income ratios of the debtors covered by the Chapter 13 Project are comparable to the debt-income ratios of the Chapter 13 debtors studied by Professors Sullivan, Warren, and Westbrook. In their study of debtors who filed for Chapter 13 relief in 1991 in ten judicial districts in Illinois, Pennsylvania, and Texas, they found a mean debt-income ratio, excluding mortgage debt, of 1.01 and a median of $0.74,{ }^{46}$ compared to 1.29 and 0.965 , respectively, for debtors in the Chapter 13 Project. The debt-income ratios for the debtors in the Chapter 13 Project also were similar to those of the debtors in a study of Mississippi Chapter 13 cases filed between 1992 and 1998, who had a mean debt-income ratio of 1.41 and a median of 1.23 .47

The debt-annual net income ratios (excluding long-term mortgage debt) naturally were somewhat lower when the entire household was

44. Poverty Thresholds: 1994, U.S. Census BUREAU, available at www.census.gov/ hhes/poverty/threshld/thresh94.html.

45. The poverty levels were established by the USDA and are adjusted by annual growth in the Consumer Price Index each year. Because certain costs, such as medical and transportation expenses, have grown at a rate greater than CPI inflation, many agencies such as the Centers for Disease Control, now adjust the United States poverty figures upwards to $129 \%$ of values published by the Census Bureau. Using this adjustment, the poverty level for a household of four was $\$ 19,531$ in 1994 .

46. Teresa A. Sullivan, Elizabeth Warren \& Jay L. Westbrook, Consumer Debtors Ten Years Later: A Financial Comparison of Consumer Bankrupts 1981-1991, 68 Ам. BANKR. L.J. 121, 124 (1994). The standard deviation was 0.97 , 25th percentile was 0.4, and 75 th percentile was 1.32. In their previous study of debtors who filed for relief in 1981 in ten of the same judicial districts, Professors Sullivan, Warren, and Westbrook found a mean debt-income ratio for Chapter 13 debtors, including mortgage debt, of 1.47 with a standard deviation of 7.45, a 25th percentile of 0.36 , a median of 0.62 , and a 75th percentile of 1.02. See Teresa A. Sullivan, Elizabeth Warren \& Jay L. Westbrook, Folklore and Facts: A Preliminary Report from the Consumer Bankruptcy Project, 60 AM. BANKR. L.J. 293, 324 (1986). The mean debt-income ratios found for debtors in the Chapter 13 Project were well within the standard deviations of the means found by Professors Sullivan, Warren, and Westbrook in their two studies.

In their study of debtors who filed for Chapter 13 relief in 1981 in ten judicial districts in Illinois, Pennsylvania, and Texas, they found a mean and median ratio of nonmortgage debt to income of 1.48 and 0.96 , respectively, for their sample of Chapter 7 and Chapter 13 debtors. Sullivan, Warren \& Westbrook, The Fragile Middle CLASS, supra note 21, at 71, table 2.5.

47. Scott F. Norberg, Consumer Bankruptcy's New Clothes: An Empirical Study of Discharge and Debt Collection in Chapter 13, 7 AM. Bankr. InST. L. REv. 415, 456-57 (1999). The Mississippi study included some mortgage debt in the computation of debtincome ratios. 
taken into account. The mean household debt-annual income ratio was 1.07 , with a median of 0.855 and standard deviation of 0.904 .

TABLE 9. DEBT-ANNUAL NET INCOME RATIOS (EXCLUDING LONG-TERM MORTGAGE DEBT)

\begin{tabular}{|l|c|c|c|c|c|c|c|c|}
\hline & $\mathrm{N}$ & Range & Mean & SD & SEM & $25 \%$ & Median & $75 \%$ \\
\hline $\begin{array}{l}\text { Debtor } \\
\text { D-ANI ratio }\end{array}$ & $\begin{array}{c}746(49 \\
\text { missing) }\end{array}$ & $0-25.17^{48}$ & 1.29 & 1.115 & 0.041 & 0.558 & 0.965 & 1.699 \\
\hline $\begin{array}{l}\text { Debtor } \\
\text { Household } \\
\text { D-ANI ratio }\end{array}$ & $\begin{array}{c}743(52 \\
\text { missing) }\end{array}$ & $0-25.17^{49}$ & 1.07 & 0.904 & 0.033 & 0.479 & 0.855 & 1.409 \\
\hline
\end{tabular}

An analysis of the sample debtors' debt-annual net income ratios by district revealed a significant relation..$^{50}$ As reflected in Figure 1 below, debtors in the Western District of Pennsylvania and Southern District of Georgia had significantly higher debt-annual net income ratios than debtors in the Western District of Tennessee, Middle District of Tennessee, and District of Maryland. ${ }^{51}$

\section{FIGURE 1. MEAN DEBTOR DEBT-ANNUAL NET INCOME RATIO BY DISTRICT}

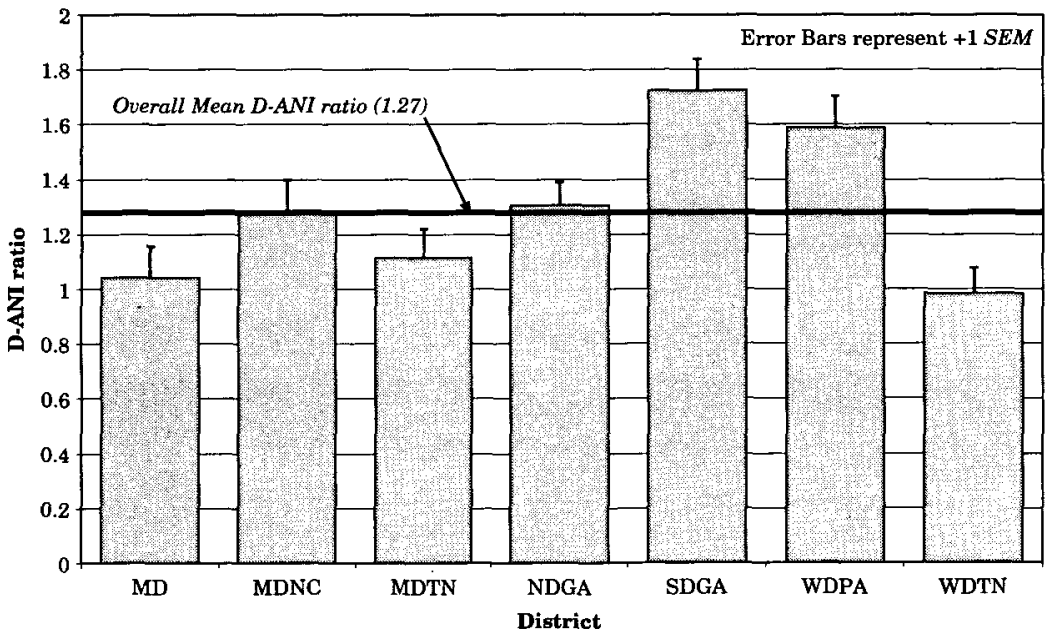

48. All ratios $>5.57(M+3 S D)$ were excluded from subsequent descriptive and inferential procedures.

49. All ratios $>6.76(M+3 S D)$ were excluded from subsequent descriptive and inferential procedures.

50. $F(6,721)=6.70, p \leq .001, \eta^{2}=.053$.

51. These post hoc analyses were performed using Dunnett's T3 test due to the inequality of variances revealed by Levene's test. 
There was likewise a significant relation between district and debtor household debt-annual net income ratios. ${ }^{52}$ As shown in Figure 2, the Southern District of Georgia had significantly higher household debt-annual net income ratios than all other districts except the Western District of Pennsylvania. ${ }^{53}$

\section{FIGURE 2. MEAN DEBTOR HOUSEHOLD DEBT-ANNUAL NET INCOME RATIO BY DISTRICT}

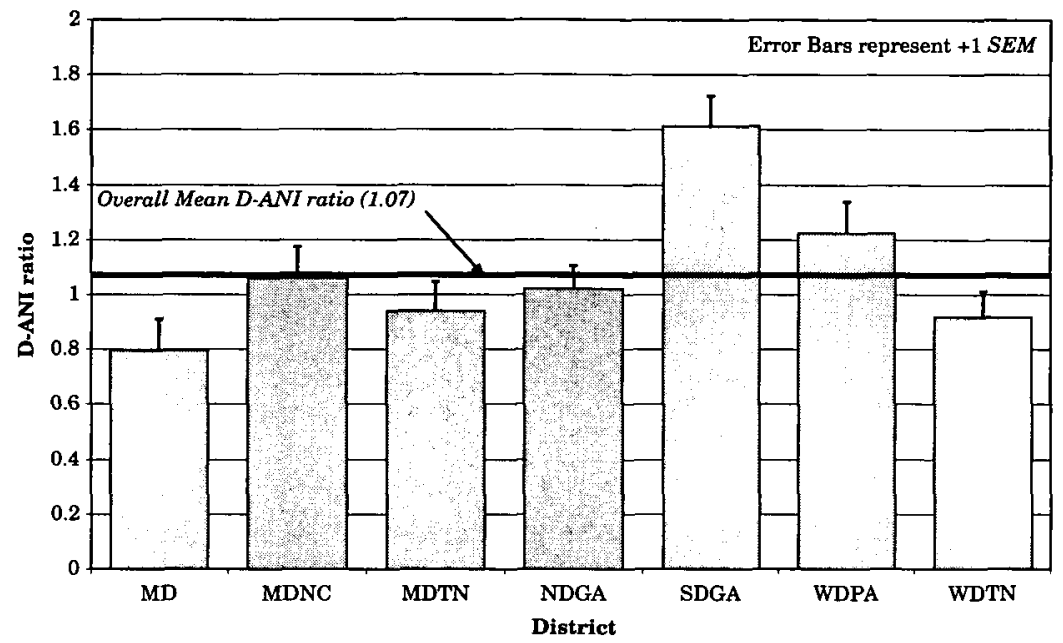

\section{Home Ownership}

Approximately $54 \%$ of the debtors in the study were homeowners, ${ }^{54}$ compared to the national rate of homeownership in 1994 of $64 \% .{ }^{55}$ The rate of debtor homeownership in the Chapter 13 Project is again similar to that found in other studies of consumer bankruptcy

52. $F(6,733)=9.15, p \leq .001, \eta^{2}=.069$.

53. These post hoc analyses were performed using Dunnett's T3 test due to the inequality of variances revealed by Levene's test.

54. Neither the Schedules, Official Bankruptcy Form 6, nor the Statement of Financial Affairs, Official Bankruptcy Form 7, includes any direct question regarding homeownership. We inferred home ownership from whether the debtor scheduled a mortgage or mobile home debt. Thus, the rate of home ownership reported here may be understated; some debtors may have owned homes without any mortgage, and some mortgage or mobile home creditors may not have been identifiable as such. 427 , or $54 \%$, of the cases indicated a mortgage or mobile home debt. We identified 16 mobile home debts in MDNC, 7 in NDGA, 5 in SDGA, and 1 each in MD and MDTN. In MDTN, we identified 42 debtors with mortgage debt, but further estimated that roughly 25 real estate mortgages were listed as priority instead of secured debts. The remaining $\mathbf{3 7 2}$ homeowners were identified as having mortgage debts.

55. Robert R. Callis, Moving to America-Moving to Homeownership: 1994-2002, Current Housing Reports (U.S. Census Bureau, Washington, D.C.), Sept. 2003, at 2, available at http://www.census.gov/prod/2003pubs/h121-03-1.pdf. 
filings. In their 1991 study of debtors in sixteen judicial districts in California, Tennessee, Illinois, Pennsylvania, and Texas, Professors Sullivan, Warren, and Westbrook found that about half of the debtors owned a home. ${ }^{56}$

There were substantial variations in homeownership rates among the seven districts. As shown in Table 10, homeownership rates ranged from a low of only 33\% - just half the national rate for all Americans - in the Middle District of Tennessee to $79 \%$ in the Western District of Pennsylvania. These substantial variations imply very different uses of Chapter 13 by debtors in the different districts, that is, that debtors in the Western District of Pennsylvania used Chapter 13 primarily for dealing with mortgage defaults, while the great majority of debtors in the Middle District of Tennessee, and nearly half of the debtors in the Northern and Southern Districts of Georgia and the Western District of Tennessee, sought Chapter 13 relief for other reasons. ${ }^{57}$

56. Sullivan, Warren \& Westbrook, The Fragile Middle Class, supra note 21, at 204. See also Norberg, 7 AM. BANKR. INST. L. REv. at 457-58 (finding that approximately $60 \%$ of Chapter 13 debtors filing between 1992 and 1998 in the Southern District of Mississippi were homeowners); Teresa A. Sullivan, Elizabeth Warren \& JaY L. Westbrook, As We Forgive Our Debtors: Bankruptcy and Consumer Credit in AMERICA 129 (1999) [hereinafter AWFOD] (reporting on study of Chapter 7 and Chapter 13 cases filed in 1991 in ten judicial districts in Texas, Pennsylvania, and Illinois; finding that $52 \%$ of Chapter 7 and Chapter 13 debtors were homeowners). Cf. Ed Flynn \& Gordon Bermant, Bankruptcy by the Numbers, . . Be it ever so humble, there's no place like home, available at http://www.usdoj.gov/ust/eo/public_affairs/articles/docs/abi_08_ 2003.htm (last visited May 19, 2006) (reporting national home ownership rate of $42 \%$ for Chapter 7 debtors in 5832 cases filed between 1999 and 2001, with variations among states ranging from 27\% to 60.4\%); Ed Flynn \& Gordon Bermant, Bankruptcy by the Numbers, The Class of 2000 , available at http:/www.usdoj.gov/ust/eo/public_affairs/articles/docs/abi01octnumbers.html (reporting 41.8\% home ownership rate for Chapter 7 debtors in 1931 no-asset Chapter 7 cases filed in 2000).

57. A chi-square analysis indicated differential rates of homeownership across the districts studied, $\Pi^{2}(6, N=795)=67.09, p \# .001$. The homeownership rate in MDTN (32.0\%) was lower than expected, and homeownership rates in MD (57\%), MDNC (58\%), and WDPA $(79.0 \%)$ were higher than expected. However, chi-square analysis did not reveal a significant relationship between homeowner status and case disposition, $\Pi^{2}(4$, $N=795)=.664, p=.956$. 
TABLE 10. FREQUENCY OF HOMEOWNERSHIP BY DISTRICT

\begin{tabular}{|l|c|c|}
\hline District & Do not own home (percent) & Homeowner (percent) \\
\hline MD & $42(42 \%)$ & $58(58 \%)$ \\
\hline MDNC & $43(43 \%)$ & $57(57 \%)$ \\
\hline MDTN & $67(67 \%)$ & $33(33 \%)$ \\
\hline NDGA & $83(50 \%)$ & $82(50 \%)$ \\
\hline SDGA & $49(49 \%)$ & $51(51 \%)$ \\
\hline WDPA & $21(21 \%)$ & $79(79 \%)$ \\
\hline WDTN & $63(48 \%)$ & $67(52 \%)^{58}$ \\
\hline Total & $368(46 \%)$ & $427(54 \%)$ \\
\hline
\end{tabular}

\section{Previous and Subsequent Bankruptcy Filings}

The study also investigated bankruptcy filings by the debtors before and after the sample case. Data were obtained from two sources: the Statement of Financial Affairs, which requires the debtor to disclose any previous filings, and electronic searches of each district's PACER database. The available data probably somewhat understate the incidence of other bankruptcy filings by the sample debtors. The PACER databases reach back before 1994 by no more than five years and are more limited in some districts than others; indeed, the PACER system reaches back only one or two years before 1994 in several of the sample districts. ${ }^{59}$ Thus, many previous filings were ascertainable only from the debtor's disclosure in the Statement of Financial Affairs, which is not entirely reliable on this point. ${ }^{60}$ Further, the PACER searches for subsequent filings were done in 2002 , so that any filings after that time are not included in the data set; and the district PACER systems are not connected to a national database, and therefore do not reveal when a debtor has filed a petition in another jurisdiction. The searches also might have missed some cases in which the sample case was a joint filing, but a previous or subsequent filing was an individual filing, or vice versa.

58. Includes twenty-five cases in which mortgage debt apparently was listed as priority debt.

59. The following chart indicates the reach of the PACER system in each district for ascertaining previous bankruptcy filings:

\begin{tabular}{|c|c|c|c|c|c|c|}
\hline NDGA & SDGA & MDTN & WDTN & MDNC & WDPA & MD \\
\hline 1992 & 1989 & 1992 & 1991 & 1993 & 1986 & 1990 \\
\hline
\end{tabular}

60. Comparison of the debtors' statements of financial affairs to the PACER search results in the Mississippi study found that nearly $25 \%$ of debtors who had filed a previous petition did not report it in their statement of financial affairs in the sample case. Norberg, 7 AM. BANKR. INST. L. REv. at 458, 458 n.128. 


\section{Other Filings (Previous or Subsequent to the Sample Case)}

Among the most remarkable findings of the Project is that at least half of all of the Chapter 13 debtors in the sample had filed one or more bankruptcy cases in addition to the sample case. As shown in Figure 3, the available data reveal that half of the debtors had filed only the sample case, while nearly $30 \%$ had filed one other case, $10 \%$ had filed two other cases, and $10 \%$ had filed three or more other cases. ${ }^{61}$ (In Part VI below, we consider the relation between other filings and outcome in the sample case.)

\section{FIGURE 3. SAMPLE CASES WITH RECORD OF OTHER FILINGS}

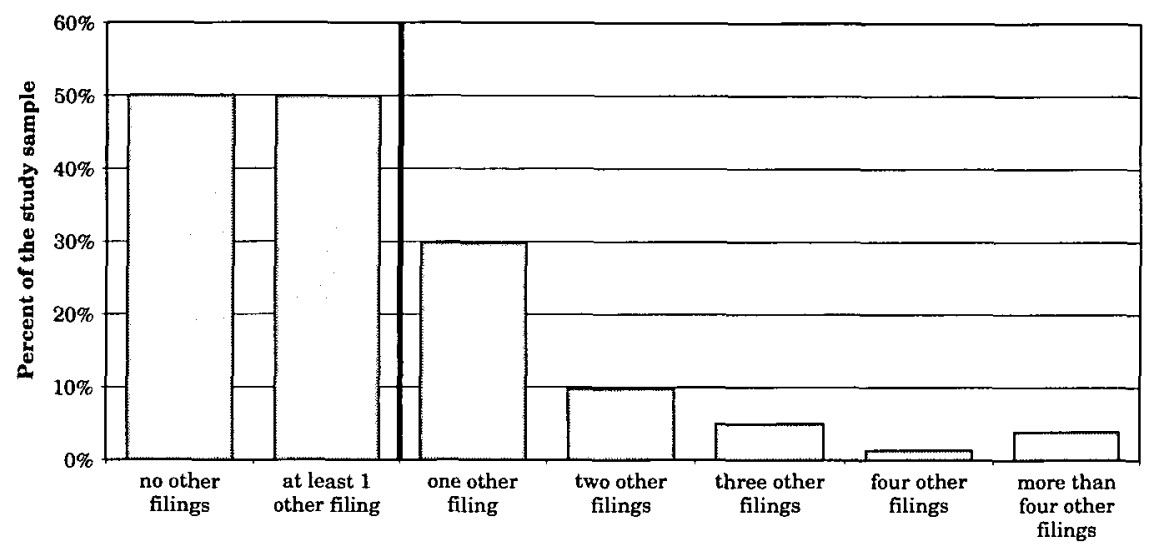

Table 11 below provides additional detail regarding the number of previous and subsequent filings by the debtors in the sample cases. Nearly $32 \%$ of the debtors had one or more previous filings; ${ }^{62}$ approxi-

61. These Project findings are consistent with findings reported by Jean M. Lown, Serial Bankruptcy: A 20-Year Study of Utah Filers, 25 Am. BANkR. INST. J. 24, 24-25, 6869 (Feb. 2006). Professor Lown's study examined repeat filings by debtors filing for bankruptcy relief in Utah in 1997. She found that $10.7 \%$ of the debtors had filed three times within two years or four or more times within twenty years. She did not report in this article on the numbers of repeat filers who had filed fewer than three times within two years or fewer than four times in twenty years.

62. Compare Norberg, 7 AM. BANKR. INST. L. REv. at 458 and n.128 (approximately $39 \%$ of debtors in sample of Chapter 13 cases filed between 1994 and 1998 in Southern District of Mississippi filed one or more previous cases), with Susan L. DeJarnatt, Once Is Not Enough: Preserving Consumers' Rights to Bankruptcy Protection, 74 IND. L.J. 455,480 (1999) (reporting that repeat filers ranged from less than $5 \%$ up to $40 \%$ of all Chapter 13 filers, based on survey completed by 62 of 179 standing Chapter 13 trustees in 1996 or 1997). It appears that some of the Chapter 13 trustees surveyed by Professor DeJarnatt may have substantially underestimated the numbers of repeat filers in their districts. Professor DeJarnatt identifies the responding trustees by state, not district within a state. According to her survey, two trustees in Tennessee estimated that less than $10 \%$ of their total caseload was repeat filings, and two others reported that repeat filings were between $31 \%$ and $40 \%$ of total caseload, $i d$. at 480 , compared to the $26 \%$ and $51 \%$ rates of previous filings reported in Figure 5 below for the Middle and Western 
mately $22 \%$ had filed one previous case, and approximately $7 \%$ had filed two or more previous cases. Approximately 33\% of the debtors have filed one or more times subsequent to the sample case; the available data are that nearly $22 \%$ of all debtors have filed one later case, and more than $11 \%$ have filed two or more subsequent cases by 2002 .

TABLE 11. PREVIOUS AND SUBSEQUENT FILINGS

\begin{tabular}{|c|c|c|c|c|c|c|c|c|c|c|c|}
\hline \multirow{2}{*}{\multicolumn{2}{|c|}{ All Districts }} & \multicolumn{9}{|c|}{ number of subsequent filings } & \multirow{3}{*}{\begin{tabular}{|c|} 
Total \\
$\begin{array}{c}560 \\
(70.4 \%)\end{array}$ \\
\end{tabular}} \\
\hline & & \multirow{2}{*}{$\begin{array}{c}0 \\
398 \\
(50.1 \%)\end{array}$} & 1 & \multirow{2}{*}{$\begin{array}{c}2 \\
\begin{array}{c}26 \\
(3.3 \%)\end{array}\end{array}$} & \multirow{2}{*}{$\begin{array}{c}3 \\
7 \\
(0.9 \%)\end{array}$} & \multirow{2}{*}{$\begin{array}{c}4 \\
2 \\
(0.2 \%)\end{array}$} & \multirow{2}{*}{5} & \multirow{2}{*}{6} & \multirow{2}{*}{7} & \multirow{2}{*}{\begin{tabular}{|c|}
8 \\
1 \\
$(0.1 \%)$
\end{tabular}} & \\
\hline \multirow{7}{*}{$\begin{array}{c}\text { number } \\
\text { of } \\
\text { previous } \\
\text { filings }\end{array}$} & 0 & & $\begin{array}{c}126 \\
(15.8 \%)\end{array}$ & & & & & & & & \\
\hline & 1 & $\begin{array}{c}111 \\
(14.0 \%)\end{array}$ & $\begin{array}{c}34 \\
(4.3 \%)\end{array}$ & $\begin{array}{c}21 \\
(2.6 \%)\end{array}$ & $\begin{array}{c}\mathbf{4} \\
(0.5 \%)\end{array}$ & $\begin{array}{c}3 \\
(0.4 \%)\end{array}$ & $\begin{array}{c}4 \\
(0.5 \%)\end{array}$ & $\begin{array}{c}1 \\
(0.1 \%)\end{array}$ & & & $\begin{array}{c}178 \\
(22.4 \%)\end{array}$ \\
\hline & 2 & $\begin{array}{c}18 \\
(2.3 \%)\end{array}$ & $\begin{array}{c}9 \\
(1.1 \%)\end{array}$ & $\begin{array}{c}5 \\
(0.6 \%)\end{array}$ & $\begin{array}{c}5 \\
(0.6 \%)\end{array}$ & $\begin{array}{c}2 \\
(0.3 \%)\end{array}$ & & & & & $\begin{array}{c}39 \\
(4.9 \%)\end{array}$ \\
\hline & 3 & $\begin{array}{c}5 \\
(0.6 \%)\end{array}$ & & $\begin{array}{c}2 \\
(0.2 \%)\end{array}$ & $\begin{array}{c}3 \\
(0.4 \%) \\
\end{array}$ & & & & & & $\begin{array}{c}10 \\
(1.3 \%)\end{array}$ \\
\hline & 4 & & $\begin{array}{c}3 \\
(0.3 \%)\end{array}$ & & $\begin{array}{c}2 \\
(0.2 \%)\end{array}$ & & & & $\left(\begin{array}{c}1 \\
(0.1 \%)\end{array}\right.$ & & $\begin{array}{c}6 \\
(0.8 \%)\end{array}$ \\
\hline & 5 & $\begin{array}{c}1 \\
(0.1 \%)\end{array}$ & & & & & & & & & $\begin{array}{c}1 \\
(0.1 \%)\end{array}$ \\
\hline & 7 & $\begin{array}{c}1 \\
(0.1 \%)\end{array}$ & & & & & & & & & $\begin{array}{c}1 \\
(0.1 \%)\end{array}$ \\
\hline Total & & $\begin{array}{c}534 \\
(67.2 \%)\end{array}$ & $\begin{array}{c}172 \\
(21.6 \%)\end{array}$ & $\begin{array}{c}54 \\
(6.8 \%)\end{array}$ & $\begin{array}{c}21 \\
(2.6 \%)\end{array}$ & $\begin{array}{c}7 \\
(0.9 \%)\end{array}$ & $\begin{array}{c}4 \\
(0.5 \%)\end{array}$ & $\begin{array}{c}1 \\
(0.1 \%)\end{array}$ & $\begin{array}{c}1 \\
(0.1 \%)\end{array}$ & $\begin{array}{c}1 \\
(0.1 \%)\end{array}$ & 795 \\
\hline
\end{tabular}

\section{Other Filings - District Comparisons}

The data indicate a statistically significant relation between judicial district and incidence of other filings. As reflected in Figure 4 below, $20 \%$ of the debtors in the Middle District of North Carolina had filed one or more subsequent cases, compared to $39 \%$ and $56 \%$ of the debtors in the Middle District of Tennessee and the Western District of Tennessee, respectively, and the overall subsequent filing rate of $33 \%$ for all debtors in all seven districts. ${ }^{63}$

The data sets on previous filings vary by district, therefore any conclusion regarding the relation between judicial district and incidence of previous filings is not possible. The PACER database for the Middle District of North Carolina reaches back only one year before

Districts of Tennessee, respectively, in the Chapter 13 Project. Likewise, she reported a $6-10 \%$ repeat filing rate estimated by a trustee in Pennsylvania, compared to $24 \%$ found in the Chapter 13 Project for the Western District of Pennsylvania; and fewer than 5\% estimated by a trustee in North Carolina, compared to $20 \%$ in MDNC in the Project. See also Harry H. Haden, Chapter XIII Wage Earner Plans - Forgotten Man Bankruptcy, 55 Ky. L.J. 564, 594-95 (1966) (reporting that 66\% of wage earner petitions filed in Birmingham, Ala., in one year were by repeat filers).

63. $\chi^{2}(6, N=793)=47.16, p \leq .001$. 
the sample cases, compared to two or more years in the other six districts.

FIGURE 4. SUBSEQUENT REFILING RATES BY DISTRICT

Percent of Current Cases with at Least One Subsequent

Filing by District $(\mathrm{N}=261)$

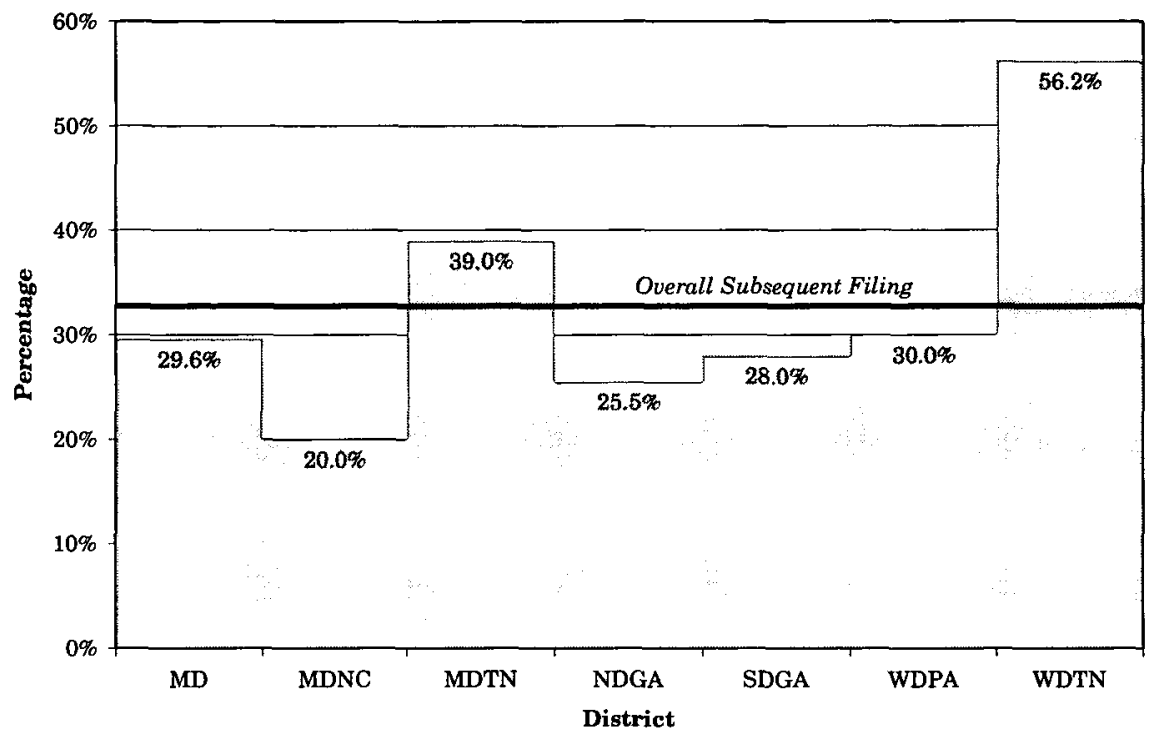

3. Abuse by Repeat Filers?

The data reported above in Figures 3-4 and Table 11 clearly suggest that there is a cadre of debtors who have misused the bankruptcy system with repeat filings. More than $10 \%$ of the debtors in the sample have filed four or more cases, including the sample case, and over $5 \%$ have filed five or more cases. At the extreme, one debtor has filed no fewer than 12 cases, four preceding the sample case and seven thereafter; another debtor has filed eight other cases, two previous and six subsequent to the sample case; another has seven previous filings; and another has filed one previous and six subsequent cases. Abuse in these cases appears manifest. In the more common cases, however, in which the debtor has filed one or two other petitions, abuse is much more difficult to infer. As discussed in the following section, the Project data base includes information on the chapter of the debtors' other filing(s), the disposition of such case(s), and the length of time between filings. While this data adds some detail to the portrait of the sample debtors' use of the consumer bankruptcy system, it sheds little light on whether the debtors with one or two other filings have abused the system. Perhaps the best available insight 
into the propriety of other filings comes from the analyses in Part VI.B. below of the relation between other filings and case outcome. ${ }^{64}$

\section{Chapter, Timing, and Outcome of Other Filings}

\section{a. Chapter of Other Filings}

The large majority of the debtors' other bankruptcy filings were also under Chapter 13. As reported in Table 12, the available data indicate that, of the debtors who had filed a single previous petition, over $80 \%$ of those for whom the chapter of the previous filing is known filed the previous case under Chapter 13. Likewise, as reported in Table 13, of the debtors who have filed a single subsequent petition, over 75\% filed the later case under Chapter 13.

\section{TABLE 12. CHAPTER OF PREVIOUS BANKRUPTCY FILING}

\begin{tabular}{|c|c|c|c|}
\hline & $\mathbf{N}$ & $\begin{array}{c}\% \text { of } 2 \text { nd } \\
\text { time filers } 65\end{array}$ & $\begin{array}{l}\% \text { of all } \\
\text { debtors }\end{array}$ \\
\hline \multirow{2}{*}{$\begin{array}{l}\text { No Previous Filings } \\
\text { One Previous Filing }\end{array}$} & 560 & - & $70.4 \%$ \\
\hline & 178 & - & 22.4 \\
\hline \multirow{2}{*}{$\begin{array}{l}\text { Under Chapter } 7 \\
\text { Under Chapter } 13\end{array}$} & 26 & $19.0 \%$ & $3.3 \%$ \\
\hline & 110 & $80.3 \%$ & $13.8 \%$ \\
\hline \multirow[t]{2}{*}{ Under Chapter 11} & 1 & $0.7 \%$ & $0.1 \%$ \\
\hline & 41 & - & - \\
\hline More than One Previous Filing & 57 & - & $7.2 \%$ \\
\hline Total & 795 & & \\
\hline
\end{tabular}

64. See also DeJarnatt, 74 IND. L.J. at 480 (reporting results of survey of 62 of 179 standing Chapter 13 trustees; 26 of 62 trustees reported that there was abuse in fewer than $10 \%$ of repeat filings, while 24 reported abuse in more than $20 \%$ of all repeat filings); Lown, 25 AM. BANKR. INST. J. at 24-25, 68-69 (finding that 10.7\% of debtors who filed for bankruptcy relief in Utah in 1997 were serial filers and possible abusers, having filed three times within two years or four or more times within twenty years).

65. Excluding missing cases. 
TABLE 13. CHAPTER OF SUBSEQUENT BANKRUPTCY FILING

\begin{tabular}{|c|c|c|c|}
\hline & $\mathrm{N}$ & $\begin{array}{c}\% \text { of } 2 \text { nd } \\
\text { time filers } 66\end{array}$ & $\begin{array}{l}\% \text { of all } \\
\text { debtors }\end{array}$ \\
\hline \multirow{2}{*}{$\begin{array}{l}\text { No Subsequent Filings } \\
\text { One Subsequent Filing }\end{array}$} & 534 & - & $67.2 \%$ \\
\hline & 172 & - & $21.6 \%$ \\
\hline \multirow{3}{*}{$\begin{array}{l}\text { Under Chapter } 7 \\
\text { Under Chapter } 13 \\
\text { missing }\end{array}$} & 29 & $24.8 \%$ & $3.6 \%$ \\
\hline & 88 & $75.2 \%$ & $11.0 \%$ \\
\hline & 55 & - & - \\
\hline \multirow[t]{2}{*}{ More than One Subsequent Filing } & 89 & - & $11.2 \%$ \\
\hline & 795 & & \\
\hline
\end{tabular}

b. Timing of Other Filings

The bulk of the sample debtors' other filings occurred within a year before the filing of the sample case or a year after the final disposition of the sample case. As reported in Table 14, of the debtors who had filed a single previous petition, the great majority - over 75\%filed the sample case within a year of the dismissal of the previous case. As reported in Table 15, of the debtors who had filed a single subsequent petition, a large majority $-65 \%$-filed the later case within a year of the disposition of the sample case.

TABLE 14. INTERVAL BETWEEN DISPOSITION OF PREVIOUS CASE AND FILING OF SAMPLE CASE

\begin{tabular}{|l|c|}
\hline Interval & $\begin{array}{c}\text { Percent of Cases with Single } \\
\text { Previous Filing }\end{array}$ \\
\hline$<0-1$ years & $75.3 \%$ \\
\hline $1-2$ years & $9.8 \%$ \\
\hline $2-3$ years & $5.7 \%$ \\
\hline $3-4$ years & $4.0 \%$ \\
\hline $4-5$ years & $2.3 \%$ \\
\hline $5-6$ years & $0.0 \%$ \\
\hline $6-7$ years & $2.3 \%$ \\
\hline $7+$ years & $0.6 \%$ \\
\hline
\end{tabular}

66. Excluding missing cases. 
TABLE 15. INTERVAL BETWEEN DISPOSITION OF SAMPLE CASE AND FILING OF SUBSEQUENT CASE

\begin{tabular}{|l|c|}
\hline Interval & $\begin{array}{c}\text { Percent of Cases with Single } \\
\text { Subsequent Filing }\end{array}$ \\
\hline $0-1$ years & 64.9 \\
\hline 1-2 years & 10.5 \\
\hline 2-3 years & 6.3 \\
\hline 3-4 years & 7.3 \\
\hline 4-5 years & 4.7 \\
\hline 5-6 years & 1.1 \\
\hline 6-7 years & 1.5 \\
\hline 7+ years & 3.7 \\
\hline
\end{tabular}

\section{c. Outcome of Other Filings}

Table 16 below reports that nearly $75 \%$ of the previous cases filed by the debtors with one previous bankruptcy filing were either dismissed or converted; and that $25 \%$ of these debtors had obtained a discharge in the previous case. Table 17 reports that $40.6 \%$ of the later cases filed by the debtors with one subsequent filing had been dismissed or converted by the time of our review of the PACER databases, $31 \%$ went to discharge, and $27.6 \%$ were still pending as of the time of the PACER search.

TABLE 16. OUTCOME IN PREVIOUS CASE (REGARDLESS OF CHAPTER)

\begin{tabular}{|l|l|c|c|}
\hline & \multicolumn{1}{|c|}{ Number } & $\%$ of 2nd time filers & $\%$ of all debtors \\
\hline discharged & 35 & $25.5 \%$ & $4.4 \%$ \\
\hline dismissed & 96 & $70.1 \%$ & $12.1 \%$ \\
\hline converted & 6 & $4.4 \%$ & $0.1 \%$ \\
\hline total & 178 (41 missing cases) & $100.00 \%$ & \\
\hline
\end{tabular}


TABLE 17. OUTCOME IN SUBSEQUENT CASE (REGARDLESS OF CHAPTER)

\begin{tabular}{|l|c|c|c|}
\hline & Number & $\begin{array}{c}\% \text { of one-time } \\
\text { subsequent filers }\end{array}$ & \% of all debtors \\
\hline Discharged & 36 & $31.0 \%$ & $4.5 \%$ \\
\hline Dismissed & 47 & $40.5 \%$ & $5.9 \%$ \\
\hline Converted & 1 & $0.1 \%$ & $0.1 \%$ \\
\hline Open & 32 & $27.6 \%$ & $4.0 \%$ \\
\hline total & $\mathbf{1 7 2}$ (56 missing cases) & $100.00 \%$ & \\
\hline
\end{tabular}

\section{Filings After Discharge in the Sample Case}

Of the 262 debtors who obtained a discharge in the sample cases, $14.9 \%$ (or $4.9 \%$ of all debtors, $N=39$ ) went on to file a subsequent case by 2002.67 Three percent (3\%) of the debtors who obtained a discharge ( 8 of 262) (or 1\%, 8 of 793) filed two or more times after having successfully completed a plan. These data confirm anecdotal comments by Chapter 13 trustees that there is a small but identifiable group of debtors who rely on a Chapter 13 trustee to manage their payments to creditors.

\section{The "True" Rate of Chapter 13 Filings}

It is commonly understood that the number of households seeking bankruptcy relief in a given period is the same as the number of petitions filed in that period. The data reported in this Part IV show that there is in fact a large disparity between these two figures and that the number of households seeking bankruptcy relief in a given year is substantially fewer than the number of petitions filed in that year. As discussed, $50 \%$ of the debtors in the Chapter 13 Project had at least one other filing, and at least approximately $70 \%$ of the other filings were made within a year of the disposition of the immediately preceding case. If the Project sample is representative of all Chapter 13 debtors, the number of petitions overstates the number of households seeking Chapter 13 relief by at least $35 \%$. In 1994, then, while debtors filed 240,639 petitions under Chapter 13 , they probably represented no more than 156,415 different households. Likewise, if the refiling rates and intervals have remained relatively constant over the past ten years, the 467,000 Chapter 13 petitions filed in 2003 represented substantially fewer households - about 303,500.

67. The $4.9 \%$ rate of refiling after discharge nearly matches the finding by Sullivan, Warren, and Westbrook in their 1981 study that as many as $4 \%$ of Chapter 13 debtors filed again after receiving a discharge. AWFOD, supra note 56, at 194. 
Concomitantly, the actual ratio of Chapter 13 filers to total consumer bankruptcy petitioners also is much lower than commonly reported. Again subject to the large caveats regarding representativeness of the Project sample and the stability of repeat filing rates over the following ten years, pre-BAPCPA Chapter 13 filers constituted only about $20 \%$, not $30 \%$, of all consumer filers in a given year. Of course, as reported above, repeat filing rates vary significantly among districts, so that the "effective Chapter 13 filing rate" will vary by district.

\section{DEBTOR FRESH START IN CHAPTER 13}

\section{A. Measuring Debtor Success in Chapter 13}

Together with repayment of creditor claims, debtor fresh start is a primary policy objective underlying Chapter 13 of the Bankruptcy Code. This Part first considers the extent to which the sample debtors achieved a fresh start or financial rehabilitation in Chapter 13. It then examines the relationship between case outcome and an array of debtor characteristics and Chapter 13 plan features. Part VI then considers creditor collections in Chapter 13 cases. Creditors naturally collect significantly more debt in cases when the debtor completes his or her plan (and receives a discharge) than in cases that are dismissed or converted either before or after confirmation of a plan.

The best, and perhaps only reliable, measure of debtor fresh start in Chapter 13 is the rate of debtor plan completion and discharge. However, debtor discharge is not necessarily tantamount to an entirely fresh start. Not all claims are dischargeable upon completion of a plan, ${ }^{68}$ and as noted above, about $15 \%$ of all debtors who attain a discharge file again for bankruptcy protection. Conversely, some Chapter 13 trustees are quick to point out that some debtors achieve a fresh start without completing performance of a plan. Some Chapter 13 debtors are able to regain their financial footing simply as a result of the breathing spell afforded by the automatic stay. This breathing spell - perhaps no longer than a few months or a year between filing and dismissal of a case - is enough to allow the debtor to cure defaults or pay off debts without further court supervision or debt relief. However, it is not possible to determine from court and trustee records whether a debtor "succeeded" in Chapter 13 short of obtaining a discharge. ${ }^{69}$ Thus, we are confined to measuring debtor fresh start in Chapter 13 based on discharge and refiling rates.

68. See 11 U.S.C. $\$ 1328$ (defining scope of the Chapter 13 discharge).

69. See generally Gordon Bermant, Bankruptcy by the Numbers, What Is "Success" in Chapter 13? Why Should We Care?, 23 AM. BANkR. INST. J. 20, 20, 65, 67 (Sept. 2004) (considering various measures of success in Chapter 13). 


\section{B. Debtor and District Discharge Rates in Chapter 13 - All CASES}

The overall discharge rate for the debtors in the seven districts covered by the Project was exactly the oft-repeated statistic of onethird. ${ }^{70}$ Sixty-seven percent $(67 \%)$ of the cases were dismissed or converted, either before or after confirmation. As reported in Table 18, over $57 \%$ of the sample cases were dismissed, and nearly $10 \%$ were converted to Chapter 7. Of the dismissed cases, one-third was dismissed before confirmation of a plan and two-thirds after confirmation; that is, about $19 \%$ of all filings were dismissed before

70. The debtor discharge rates found in other studies have ranged from $20.35 \%$ to 36\%. See Jean Braucher, An Empirical Study of Debtor Education in Bankruptcy: Impact on Chapter 13 Completion Not Shown, 9 AM. BANKR. Inst. L. Rev. 557, 557, 557 n.5 (2001) (majority of Chapter debtors in empirical study of filings in five judicial districts did not achieve discharge); Personal Bankruptcy: A Literature Review, CBO PAPER, (Congressional Budget Office), Sept. 2000, 30-31, available at http://www.cbo.gov/ ftpdocs/24xx/doc2421/Bankruptcy.pdf (reporting that an average of $36 \%$ of consumers filing Chapter 13 successfully completed their plans, but that this rate is probably understated because some of the dismissed cases may represent multiple filings by the same debtor or "face filings" that may have been dismissed before their plans were confirmed); Gordon Bermant \& Ed Flynn, Bankruptcy by the Numbers, Measuring Projected Performance in Chapter 13: Comparisons Across the States, 19 AM. BANkr. INST. J. 22, 22 (July/Aug. 2000) ("[c]ompletion rates hover nationally at about one-third of confirmed plans, but this national average is a composite made up of extremely variable figures arising from different courtrooms, divisions and districts") (citing http://www. usdoj.gov/ust/statistics/stats-new/05/statistics5.htm); Scott F. Norberg, Consumer Bankruptcy's New Clothes: An Empirical Study of Discharge and Debt Collection in Chapter 13, 7 AM. BankR. Inst. L. Rev. 415, 440 (1999); Michael Bork \& Susan D. Tuck, Administrative Office of the Courts, Bankruptcy Statistical Trends, Chapter 13 Dispositions (Working Paper 2) (reporting survey of chapter 13 cases filed between 1980 and 1988); Teresa A. Sullivan, Elizabeth Warren \& Jay L. Westbrook, As We Forgive Our Debtors: Bankruptcy and Consumer Credit in America 215-17 (1999) (reporting on study of chapter 7 and chapter 13 cases filed in 1981 in ten judicial districts in Pennsylvania, Texas, and Illinois); Jim Wannamaker, The Washington Beat, 6 NAT'L Ass'N Chapter Thirteen Trustees NewsletTer No. 1, 7 (Oct. 1993); Michael Catrett, Bankruptcy by the Numbers, A Month of Debtors "Foreclosure Tuesday" and the Rush to Chapter 13 in the Houston Division of the Southern District of Texas, 24 AM. BANkR. INST. J. 24, 24 (May 2005) (finding discharge rate of 23\% for Chapter 13 cases filed in the Houston Division of the Southern District of Texas in 1999); Henry E. Hildebrand, III, Administering Chapter 13-At What Price?, 13 Am. BankR. INST. J. 16, 16 (July/Aug. 1994) (noting "trustees estimated that the completion rate of chapter 13 cases averaged 32.89 percent"). See also William C. Whitford, The Ideal of Individualized Justice: Consumer Bankruptcy As Consumer Protection, and Consumer Protection in Consumer Bankruptcy, 68 AM. BANKR. L.J. 397, 410 (1994) (reporting results of unpublished survey conducted by the National Association of chapter 13 trustees that cumulated data from chapter 13 trustees by U.S. Trustee region; the unweighted average of the trustees' reports of the percentage of chapter 13 cases that were closed in 1993 as completed ranged from $3 \%$ to $49 \%$ across twenty-two regions, with average reported rate of $31 \%$ ); cf. Marjorie L. Girth, The Role of Empirical Data in Developing Bankruptcy Legislation for Individuals, 65 IND. L.J. 17, 42 (1989) (reporting study of chapter 13 cases filed in Buffalo Division of Western District of New York between 1979 and 1982, finding discharge rate over $60 \%$ in cases in which a plan was confirmed). 
confirmation, and $38 \%$ after confirmation of a plan. The courts confirmed a plan in nearly $78 \%$ of all cases.

TABLE 18. DISCHARGE, DISMISSAL, AND CONVERSION RATES - ALL CASES $(N=794$ CASES $)$

\begin{tabular}{|c|c|c|c|c|}
\hline \multicolumn{2}{|c|}{ Dismissal } & \multicolumn{2}{c|}{$\begin{array}{c}\text { Conversion } \\
\text { 455 cases }(57.3 \%)\end{array}$} & $\begin{array}{c}\text { Discharge } \\
262 \text { cases }(33 \%)\end{array}$ \\
\hline $\begin{array}{c}\text { Before } \\
\text { Confirmation }\end{array}$ & $\begin{array}{c}\text { After } \\
\text { Confirmation }\end{array}$ & $\begin{array}{c}\text { Before } \\
\text { Confirmation }\end{array}$ & $\begin{array}{c}\text { After } \\
\text { Confirmation }\end{array}$ & \\
\hline $\begin{array}{c}154 \text { cases } \\
(19.4 \%)\end{array}$ & $\begin{array}{c}301 \text { cases } \\
(37.9 \%)\end{array}$ & $\begin{array}{c}27 \text { cases } \\
(3.4 \%)\end{array}$ & $\begin{array}{c}50 \text { cases } \\
(6.3 \%)\end{array}$ & \\
\hline
\end{tabular}

Table 19 below reports the discharge, dismissal, and conversion rates by district, in order from left to right of lowest to highest rate of debtor discharge. As a percentage of all filings, the discharge rates in the seven districts ranged from a low of $20 \%$ of Chapter 13 filings in the Western District of Tennessee to a high of $47 \%$ in the Middle District of North Carolina. The average discharge rate among districts was $33.8 \%$, almost identical to the overall rate of $33 \%$ for all debtors in the sample. Excluding converted cases, ${ }^{71}$ statistical analysis reveals significant differences in disposition rates between districts. ${ }^{72}$

TABLE 19. DISCHARGE, DISMISSAL, AND CONVERSION RATES - ALL CASES, BY DISTRICT

\begin{tabular}{|l|r|r|r|r|r|r|r|r|}
\hline Disposition & WDTN & MDTN & NDGA & SDGA & MD & WDPA & MDNC & TOTAL \\
\hline $\begin{array}{l}\text { Debtor discharged/ } \\
\text { case completed }\end{array}$ & 26 & 29 & 51 & 36 & 36 & 37 & 47 & 262 \\
\hline $\begin{array}{l}\text { Case dismissed } \\
\text { after confirmation }\end{array}$ & $51.5 \%$ & $44.0 \%$ & $37.0 \%$ & $40.0 \%$ & $7.3 \%$ & $21.0 \%$ & $41.0 \%$ & $37.9 \%$ \\
\hline $\begin{array}{l}\text { Case dismissed } \\
\text { before confirmation }\end{array}$ & $33.1 \%$ & $9.0 \%$ & $27.3 \%$ & $17.0 \%$ & $21.2 \%$ & $24.0 \%$ & $8.0 \%$ & $19.4 \%$ \\
\hline $\begin{array}{l}\text { Case converted } \\
\text { after confirmation }\end{array}$ & $5.8 \%$ & $13.0 \%$ & $3.6 \%$ & $5.0 \%$ & $11.1 \%$ & $10.0 \%$ & $0.0 \%$ & 50 \\
\hline $\begin{array}{l}\text { Case converted } \\
\text { before confirmation }\end{array}$ & $1.5 \%$ & $5.0 \%$ & $1.2 \%$ & $2.0 \%$ & $4.0 \%$ & $8.0 \%$ & $4.0 \%$ & $3.4 \%$ \\
\hline subtotal of cases & 130 & 100 & 165 & 100 & 99 & 100 & 100 & $79 \%$ \\
\hline Missing cases & 0 & 0 & 0 & 0 & 1 & 0 & 0 & 1 \\
\hline Total cases & 130 & 100 & 165 & 100 & 100 & 100 & 100 & 795 \\
\hline
\end{tabular}

C. Debtor and District Discharge Rates - Cases with a CONFIRMEd PLAN

Although Chapter 13 discharge rates normally are reported as a percentage of all Chapter 13 filings, it may be more instructive to re-

71. $N=77$.

72. $\chi^{2}(4, N=717)=49.71, p<.001$. 
port discharge rates based only on cases in which the court confirmed a plan, excluding cases in which the debtor did not obtain confirmation. (As reported in Table 18 above, nearly $23 \%$ of the sample cases were dismissed or converted before confirmation of a plan.) Cases dismissed or converted before confirmation normally are dismissed or converted within several months after filing. ${ }^{73}$ Some or many of these cases were filed by debtors who did not propose a plan with any serious intent to confirm it or did not file a plan at all. Neither the court nor the trustee has any immediate control over these filings (although their practices in regard to repeat filings may have an ex ante impact on such filings).

Tables 20 and 21 show the overall, and district by district, discharge, dismissal, and conversion rates, excluding the cases that were dismissed or converted before confirmation. In Table 21, the districts again are ordered from left to right from lowest to highest rate of debtor discharge. The discharge rates naturally are considerably higher when computed without cases dismissed or converted before confirmation. Discharge rates ranged from a low of $26.5 \%$ in the Western District of Tennessee to a high of $54.4 \%$ in the Western District of Pennsylvania, with an overall rate of $42.7 \%$ for all debtors in the sample. The average district rate was $43.5 \%$. The order of districts in Table 21 is almost the same as to the order of districts in Table 19, which includes cases dismissed before confirmation; the Western District of Pennsylvania supplants the Middle District of North Carolina by one percentage point as having had the highest rate of discharge among the seven districts.

TABLE 20. DISCHARGE, DISMISSAL, AND CONVERSION RATES (EXCLUDING CASES DISMISSED OR CONVERTED BEFORE CONFIRMATION $)(N=794$ CASES $)$

\begin{tabular}{|c|c|c|}
\hline \multicolumn{2}{|c|}{ Dismissal and Conversion After Confirmation } & Discharge \\
\hline \multicolumn{2}{|c|}{351 cases $(57.3 \%)$} & 262 cases $(42.7 \%)$ \\
\hline $\begin{array}{l}\text { Dismissal After } \\
\text { Confirmation }\end{array}$ & $\begin{array}{c}\text { Conversion After } \\
\text { Confirmation }\end{array}$ & \\
\hline 301 cases $(49.1 \%)$ & 50 cases $(8.2 \%)$ & \\
\hline
\end{tabular}

73. See infra notes 154-57 and accompanying text (discussing time spent by debtors in chapter 13 cases) and Table 39. 
TABLE 21. DISCHARGE, DISMISSAL, AND CONVERSION RATES-EXCLUDING CASES DISMISSED OR CONVERTED BEFORE CONFIRMATION, BY DISTRICT

\begin{tabular}{|l|r|r|r|r|r|r|r|r|}
\hline Disposition & WDTN & MDTN & NDGA & SDGA & MD & MDNC & WDPA & TOTAL \\
\hline $\begin{array}{l}\text { Debtor } \\
\text { discharged/case } \\
\text { completed }\end{array}$ & $26.5 \%$ & $33.7 \%$ & $43.2 \%$ & $44.4 \%$ & $48.6 \%$ & $53.4 \%$ & $54.4 \%$ & $42.7 \%$ \\
\hline $\begin{array}{l}\text { Case dismissed } \\
\text { after confirmation }\end{array}$ & $68.4 \%$ & $51.2 \%$ & $51.7 \%$ & $49.4 \%$ & $36.5 \%$ & $46.6 \%$ & $30.9 \%$ & $49.1 \%$ \\
\hline $\begin{array}{l}\text { Case converted } \\
\text { after confirmation }\end{array}$ & $5.1 \%$ & $15.1 \%$ & $5.1 \%$ & $6.2 \%$ & $14.9 \%$ & $0.0 \%$ & $14.7 \%$ & $8.2 \%$ \\
\hline subtotal & 98 & 86 & 118 & 81 & 74 & 88 & 68 & 613 \\
\hline Missing & 0 & 0 & 0 & 0 & 1 & 0 & 0 & 1 \\
\hline Total & 98 & 86 & 118 & 81 & 75 & 88 & 68 & 614 \\
\hline
\end{tabular}

\section{Relationship Between Pre-Confirmation Dismissal and Discharge RATES}

We expected but did not find an inverse relation between the rate of pre-confirmation dismissals and the rate of debtor discharge. The cases that the debtor or the court dismisses without confirmation of a plan are the cases that are least likely to succeed, so that more dismissals would correlate with higher discharge rates as a percentage of cases with a confirmed plan. Yet, as shown in Table 22 below, the district with the highest rate of discharge - the Middle District of North Carolina - had the lowest rate of pre-confirmation dismissals and conversions, while the district with the second highest rate of discharge - the Western District of Pennsylvania - had the highest rate of pre-confirmation dismissals and conversions. Conversely, the district with the lowest rate of discharge - the Western District of Tennessee - had among the higher rates of pre-confirmation dismissals and conversions, while the district with the second lowest rate of discharge - the Middle District of Tennessee - also had the second lowest rate of pre-confirmation dismissals and conversions.

The absence of any correlation between the rate of pre-confirmation dismissals and conversions and the rate of debtor discharge suggests that some courts generally do not carefully screen cases for feasibility. In fact, courts and trustees may see little downside in allowing debtors to proceed with even the most unrealistic plans. Absent any creditor objection based on the treatment of its claim, the alternative is dismissal or conversion to Chapter 7, in which unsecured creditors are not likely to collect anything. As the chief judge in one of the sample districts remarked, the test for feasibility is a 
"heartbeat" test; if the debtor has a heartbeat, the plan is feasible. ${ }^{74}$ One exception may be the Western District of Pennsylvania, which had fewer than expected dismissals after confirmation and more than expected dismissals before confirmation. ${ }^{75}$

TABLE 22. COMPARISON OF DISCHARGE, AND DISMISSAL/ CONVERSION BEFORE CONFIRMATION RATES, BY DISTRICT

\begin{tabular}{|l|c|c|c|c|c|c|c|c|}
\hline & WDTN & MDTN & NDGA & SDGA & MD & WDPA & MDNC & ALL \\
\hline $\begin{array}{l}\text { Dismissals and } \\
\text { Conversions Before } \\
\text { Confirmation } \\
\text { (as \% of all cases) }\end{array}$ & $24.6 \%$ & $14.0 \%$ & $28.5 \%$ & $19.0 \%$ & $25.2 \%$ & $32.0 \%$ & $12.0 \%$ & $22.8 \%$ \\
\hline $\begin{array}{l}\text { Discharges } \\
\text { (as \% of all cases) }\end{array}$ & $20.0 \%$ & $29.0 \%$ & $30.9 \%$ & $36.0 \%$ & $36.4 \%$ & $37.0 \%$ & $47.0 \%$ & $33.0 \%$ \\
\hline $\begin{array}{l}\text { Discharges } \\
\text { (as \% of cases with } \\
\text { confirmed plan) }\end{array}$ & $26.5 \%$ & $33.7 \%$ & $43.2 \%$ & $44.4 \%$ & $48.6 \%$ & $54.4 \%$ & $53.4 \%$ & $42.7 \%$ \\
\hline
\end{tabular}

\section{PREDICTING OUTCOME IN CHAPTER 13 CASES}

The modest rates of debtor discharge in Chapter 13 found in this and other studies, together with the data in Part VII below demonstrating a close, positive association between debtor discharge and creditor collections, invite an examination of factors that may be related to case outcome. This Part now considers a number of variables, which can be gleaned from court and trustee records, that may bear on case outcome: (a) certain debtor characteristics, including gender, joint filing status, income, amount and type of debt, and debt-income

74. See also Lynn M. LoPucki, Common Sense Consumer Bankruptcy, 71 Am. BANKR. L.J. 461, 474-75 (1997). LoPucki commented the following:

In the early years, the courts probably were unaware that they were routinely confirming plans with which debtors were unable to comply. When Sullivan, Warren and Westbrook estimated the failure rate at two-thirds in 1989, their estimate was hotly disputed. But data gathered since then show a continuation of the failure rate at about two-thirds.

One might expect that in response to these revelations, judges would have changed their standards for confirmation of Chapter 13 plans. Based on anecdotal evidence gathered in conversations with a few judges, however, that does not seem to be the case. Judges committed to Chapter 13 and the moralistic view of the purpose of bankruptcy see no contradiction between Bankruptcy Code $\$ 1325(a)(6)$ and the high failure rates of the plans they confirm. They simply interpret the statute as though it said "might" rather than "will."

LoPucki, 71 Am. Bankr. L.J. at 474-75.

But see Gary Neustadter, When Lawyer and Client Meet: Observations of Interviewing and Counseling Behavior in the Consumer Bankruptcy Law Office, 35 BuFF. L. REv. 177, 204 (1986) (stating the local bankruptcy judge carefully assessed feasibility of proposed Chapter 13 plans).

75. The combination of a lower discharge rate and higher pre-confirmation dismissal rate reported in Table 21 for the Western District of Tennessee may have been a function of the very high numbers of serial filers there. See supra note 63 and accompanying text and Figure 4. 
ratio, (b) other bankruptcy filings, and (c) Chapter 13 plan features, including household budget, proposed plan payments, amount of income reserved for living expenses, proposed distribution to unsecured creditors, and proposed plan length.

\section{A. Debtor Characteristics and Case Outcome \\ 1. Gender, Joint Filing Status, and Case Outcome}

Among cases in which the gender of the individual petitioner could be reasonably surmised $(N=567)$, there was no significant relation between discharge, dismissal, or conversion rates and the gender of the petitioner. ${ }^{76}$ As reported in Table 23 below, almost $30 \%$ of men filing individually obtained a discharge, compared to $26 \%$ of the women; $36.4 \%$ of filings by individual men were dismissed after confirmation, compared to $44.5 \%$ of filings by women; and $25.2 \%$ of filings by individual men were dismissed before confirmation, compared to $20.4 \%$ of filings by women.

\section{TABLE 23. CASE DISPOSITION BY GENDER}

\begin{tabular}{|l|c|c|c|c|c|c|}
\hline & \multicolumn{5}{|c|}{ Case Disposition } & \\
\hline $\begin{array}{l}\text { Gender of } \\
\text { Individual filer }\end{array}$ & Discharged & $\begin{array}{c}\text { Dismissed } \\
\text { after } \\
\text { Confirmation }\end{array}$ & $\begin{array}{c}\text { Dismissed } \\
\text { before } \\
\text { Confirmation }\end{array}$ & $\begin{array}{c}\text { Converted } \\
\text { after } \\
\text { Confirmation }\end{array}$ & $\begin{array}{c}\text { Converted } \\
\text { before } \\
\text { Confirmation }\end{array}$ & Total \\
\hline Men & $84(29.4 \%)$ & $104(36.4 \%)$ & $72(25.2 \%)$ & $18(6.3 \%)$ & $8(2.8 \%)$ & 286 \\
\hline Women & $73(26 \%)$ & $125(44.5 \%)$ & $57(20.3 \%)$ & $19(6.8 \%)$ & $7(2.5 \%)$ & 281 \\
\hline Total & $157(27.2 \%)$ & $229(40.4 \%)$ & $129(22.8 \%)$ & $37(6.5 \%)$ & $15(2.6 \%)$ & 567 \\
\hline
\end{tabular}

On the other hand, as reported in Table 24 below, joint petitioners were significantly more likely to achieve a discharge than debtors who filed individually. The discharge rate (47.3\%) in jointly filed cases was substantially higher than the discharge rate for individual petitioners (28.0\%). Correspondingly, the dismissal rate in jointly filed cases was substantially lower $(41.5 \%)$ than the dismissal rate in cases filed by individual petitioners $(62.5 \%) .77$ There were no differences in conversion rates between joint and individual petitioners.

The significant, positive correlation between joint filing status and discharge does not appear to be related to the presence of a second income, however. The discharge rate for the 102 (of 585) individual filers who reported spousal income was not significantly different than that for individual filers not reporting spousal income. ${ }^{78}$

76. $\chi^{2}(4, N=567)=4.49, p=.344$.

77. $\chi^{2}(4, N=793)=32.61, p \leq .001$.

78. $\chi^{2}(4, N=586)=5.04, p=.283$. Moreover, both spouses did not necessarily have income in the jointly filed cases. Data on spousal income are missing in 56, or $28 \%$, of the 202 jointly filed cases. 
TABLE 24. FILING STATUS BY CASE DISPOSITION

\begin{tabular}{|l|c|c|c|c|c|c|}
\hline & \multicolumn{5}{|c|}{ Case Disposition } & \\
\hline Filing Status & Discharged & $\begin{array}{c}\text { Dismissed } \\
\text { after } \\
\text { Confirmation }\end{array}$ & $\begin{array}{c}\text { Dismissed } \\
\text { before } \\
\text { Confirmation }\end{array}$ & $\begin{array}{c}\text { Converted } \\
\text { after } \\
\text { Confirmation }\end{array}$ & $\begin{array}{c}\text { Converted } \\
\text { before } \\
\text { Confirmation }\end{array}$ & Total \\
\hline Individual & $164(28.0 \%)$ & $236(40.3 \%)$ & $132(22.5 \%)$ & $38(6.5 \%)$ & $16(2.7 \%)$ & 586 \\
\hline Joint & $98(47.3 \%)$ & $64(30.9 \%)$ & $22(10.6 \%)$ & $16(7.7 \%)$ & $7(3.4 \%)$ & 207 \\
\hline Total & 262 & 300 & 154 & 54 & 23 & 793 \\
& & & 2 missing) \\
\hline
\end{tabular}

\section{Debtor and Household Income}

Table 6 in Part IV.B above reports on debtor and debtor household, annual gross and net income. Here, we investigate the association, if any, between income and case outcome. Table 25 below details annual gross and net incomes for debtors and their households in cases in which the debtor obtained a discharge and in cases that were dismissed or converted. ${ }^{79}$ Debtors who achieved a discharge had significantly higher household (but not individual ${ }^{80}$ ) net incomes than debtors whose cases were dismissed. ${ }^{81}$ The median net income of the debtor households in the cases in which the debtor achieved a discharge was $\$ 20,520$, compared to $\$ 17,376$ for the debtor households in dismissed cases.

Debtors who completed their plans also had significantly higher gross incomes, ${ }^{82}$ and their households had significantly higher gross incomes ${ }^{83}$ than the debtors in cases that were dismissed. ${ }^{84}$ The me-

Relatedly, in cases when spousal income was more than $\$ 0$, there was no difference in amount of spousal gross income between jointly filed cases $(M=\$ 1261.75, S E M=$ $78.5)$ and individually filed cases with spousal income $(M=\$ 1253, S E M=69.1), t(246)=$ $.079, p=.937$. There also was no difference in spousal net income between jointly filed cases $(M=\$ 1007.56, S E M=55.6)$ and individually filed cases with spousal income $(M=$ $\$ 996.57, S E M=53.1), t(246)=.140, p=.889$.

79. "Gross income" refers to all income of the debtor or household. "Net income" refers to income minus payroll deductions. "Household income" refers to the combined incomes of the debtor and any spouse. See Schedules, Schedule I, Form 6, Official Bankruptcy Forms. Schedule I, Current Income of Individual Debtor(s), requires the debtor to itemize the debtor's monthly gross income and payroll deductions and itemize the debtor's spouse's monthly gross income and payroll deductions, if the debtor is married, regardless of whether the petition was a joint petition with the spouse. Schedule J, Current Expenditures of Individual Debtor(s), requires the debtor to provide a monthly budget for the household. Thus, debtor net income (before plan payments) and household net income can be readily computed by subtracting total monthly expenses in Schedule $J$ from monthly income in Schedule $I$.

80. While the ANOVA on debtor net income approached significance, $F(2,687)=$ $2.53, p=.08$, eta-sq $=.007$, the assumption of a significant $F$ to justify the use of post hoc Scheffe' tests is not met. Regardless, the post hoc analyses did not indicate any trend toward significance in these between-group differences, all p's $>=.117$.

81. Scheffe' tests at an alpha level of .05 .

82. $F(2,684)=4.75, p=.009, \eta^{2}=.014$.

83. $F(2,680)=9.87, p \leq .001, \eta^{2}=.028$. 
dian gross income of the individual debtors in the cases in which the debtor achieved a discharge was $\$ 20,796$, compared to $\$ 17,298$ for the individual debtors in dismissed cases. The median gross income of the debtor households in the cases in which the debtor achieved a discharge was $\$ 25,392$, compared to $\$ 20,400$ for the debtor households in dismissed cases.

\section{TABLE 25. DEBTOR INCOME AND DISCHARGE IN} CHAPTER 13

\begin{tabular}{|c|c|c|c|c|c|c|c|c|c|c|}
\hline & & & $\mathbf{N}$ & Range & Mean & SD & SEM & $25 \%$ & Median & $75 \%$ \\
\hline \multirow{4}{*}{$\begin{array}{c}\text { Debtor } \\
\text { obtained } \\
\text { discharge }\end{array}$} & \multirow{2}{*}{ Petitioner } & $\begin{array}{c}\text { Gross } \\
\text { Income }\end{array}$ & $\begin{array}{c}257 \text { (4 } \\
\text { missing) }\end{array}$ & $\$ 0-\$ 74,388$ & $\$ 22,285$ & $\$ 11,884$ & $\$ 741$ & $\$ 14,400$ & $\$ 20,796$ & $\$ 27,972$ \\
\hline & & \begin{tabular}{|c|} 
Net \\
Income
\end{tabular} & $\begin{array}{c}258 \text { (3 } \\
\text { missing) }\end{array}$ & $\$ 0-\$ 49,800$ & $\$ 17,449$ & $\$ 8,733$ & $\$ 544$ & $\$ 11,817$ & $\$ 16,164$ & $\$ 21,864$ \\
\hline & \multirow{2}{*}{ Household } & \begin{tabular}{|c|} 
Gross \\
Income \\
\end{tabular} & $\begin{array}{c}253 \text { ( } 8 \\
\text { missing) }\end{array}$ & $\$ 0-\$ 74,388$ & $\$ 28,014$ & $\$ 13,779$ & $\$ 866$ & $\$ 18,138$ & $\$ 25,392$ & $\$ 36,084$ \\
\hline & & $\begin{array}{c}\text { Net } \\
\text { Income }\end{array}$ & $\begin{array}{c}254(7 \\
\text { missing) }\end{array}$ & $\$ 0-\$ 56,508$ & $\$ 21,910$ & $\$ 20,520$ & $\$ 631$ & $\$ 14,361$ & $\$ 20,520$ & $\$ 27,564$ \\
\hline \multirow{4}{*}{$\begin{array}{c}\text { Case } \\
\text { dismissed } \\
\text { or } \\
\text { converted }\end{array}$} & \multirow{2}{*}{ Petitioner } & \begin{tabular}{|l} 
Gross \\
Income
\end{tabular} & $\begin{array}{l}434 \text { (21 } \\
\text { missing) }\end{array}$ & $\begin{array}{c}\$ 0- \\
\$ 227,880^{85}\end{array}$ & $\$ 20,835$ & $\$ 16,443$ & $\$ 789$ & $\$ 12,714$ & $\$ 17,298$ & $\$ 25,305$ \\
\hline & & $\begin{array}{c}\text { Net } \\
\text { Income }\end{array}$ & $\begin{array}{c}435 \text { (20 } \\
\text { missing) }\end{array}$ & $\begin{array}{c}\$ 0- \\
\$ 480,000^{86}\end{array}$ & $\$ 18,596$ & $\$ 26,607$ & $\$ 1,276$ & $\$ 7,210$ & $\$ 14,928$ & $\$ 21,168$ \\
\hline & \multirow{2}{*}{ Household } & $\begin{array}{c}\text { Gross } \\
\text { Income }\end{array}$ & $\begin{array}{l}433 \text { (22 } \\
\text { missing) }\end{array}$ & $\begin{array}{c}\$ 0- \\
\$ 236,316^{87}\end{array}$ & $\$ 24,758$ & $\$ 18,650$ & $\$ 896$ & $\$ 9,758$ & $\$ 20,400$ & $\$ 30,756$ \\
\hline & & \begin{tabular}{|c|} 
Net \\
Income
\end{tabular} & $\begin{array}{l}434(21 \\
\text { missing) }\end{array}$ & $\begin{array}{c}\$ 0- \\
\$ 480,000 \\
88\end{array}$ & $\$ 21,782$ & $\$ 27,374$ & $\$ 1,314$ & $\$ 8,460$ & $\$ 17,376$ & $\$ 25,524$ \\
\hline
\end{tabular}

\section{Creditor Claims and Case Outcome}

The Chapter 13 Project also investigated any relation between case outcome and amount and type of pre-bankruptcy debt. Table 26 below reports the amounts of secured, priority, general unsecured, and total debt in (1) cases in which the debtor obtained a discharge, (2) cases dismissed or converted after confirmation of a plan, and (3) cases dismissed or converted before confirmation. We found a significant relation between case outcome and a debtor's (a) allowed unsecured debts, ${ }^{89}$ and (b) total combined allowed secured, priority, and general unsecured debts. ${ }^{90}$ Debtors with greater unsecured debt and greater total combined debts tended to complete their plans and ob-

84. Scheffe' tests at an alpha level of .05 .

85. All amounts $>\$ 70,164(M+3 S D)$ were excluded from subsequent descriptive and inferential procedures.

86. All amounts $>\$ 98,412(M+3 S D)$ were excluded from subsequent descriptive and inferential procedures.

87. All amounts $>\$ 80,700(M+3 S D)$ were excluded from subsequent descriptive and inferential procedures.

88. All amounts $>\$ 103,896(M+3 S D)$ were excluded from subsequent descriptive and inferential procedures.

89. Mann-Whitney $\mathrm{U}=29488, z=-4.796, p \# .001$.

90. Mann-Whitney $\mathrm{U}=33134, z=-2.303, p=.021$. 
tain a discharge at higher rates than debtors with lesser unsecured and total combined debts whose cases were dismissed after confirmation. However, the debtors who completed their plans did not have significantly greater secured ${ }^{91}$ or priority debt than debtors who did not obtain a discharge.

As further reported in Table 26, the median amounts of total debt for debtors who completed their plans was $\$ 19,375$, compared to $\$ 14,373$ for debtors whose cases were dismissed after confirmation and $\$ 9,386$ for debtors whose cases were dismissed before confirmation. Perhaps debtors who completed their plans were more likely to have delayed filing bankruptcy, while continuing to take on debt, and thus the correlation between amount of debt and case outcome indicates that debtors who delay filing are more likely to complete their plans. Arguably, debtors who struggled longer with paying their debts before filing bankruptcy were more likely to make the effort necessary to complete their plans after filing.

91. As discussed above, we excluded long-term mortgage debts from this analysis. As a result, secured debt is substantially understated here. See supra notes 14-19 and accompanying text. 
TABLE 26. CREDITOR CLAIMS IN COMPLETED AND DISMISSED CASES

\begin{tabular}{|c|c|c|c|c|c|c|c|c|c|c|c|c|}
\hline & & $\mathbf{N}$ & $\begin{array}{c}\# \text { cases } \\
\text { with } \\
\text { value }= \\
\$ 0\end{array}$ & Range 92 & Mean & SD & SEM & $10 \%$ & $25 \%$ & Median & $75 \%$ & $90 \%$ \\
\hline \multirow{4}{*}{$\begin{array}{c}\text { Debtor } \\
\text { Obtained } \\
\text { Discharge }\end{array}$} & Secured & $\begin{array}{c}258 \text { (4 } \\
\text { missing) }\end{array}$ & $\begin{array}{c}36 \\
(14 \%)\end{array}$ & $\begin{array}{c}\$ 0- \\
\$ 210,691\end{array}$ & $\$ 11,941$ & $\$ 18,231$ & 1135 & $\$ 0$ & $\$ 1,688$ & $\$ 7,094$ & $\$ 15,458$ & $\$ 27,910$ \\
\hline & Priority & $\begin{array}{c}256(6 \\
\text { missing }\end{array}$ & $\begin{array}{c}136 \\
(52 \%)\end{array}$ & $\begin{array}{c}\$ 0- \\
\$ 46,500\end{array}$ & $\$ 1,506$ & $\$ 4,779$ & 298 & $\$ 0$ & $\$ 0$ & $\$ 0$ & $\$ 928$ & $\$ 3,273$ \\
\hline & General & $\begin{array}{c}258 \text { (4 } \\
\text { missing) }\end{array}$ & $13(5 \%)$ & $\begin{array}{c}\$ 0 \\
\$ 257,377\end{array}$ & $\$ 13,891$ & $\$ 26,512$ & 1,650 & $\$ 609$ & $\$ 3,222$ & $\$ 7,616$ & $\$ 14,477$ & $\$ 25,223$ \\
\hline & Total & $\begin{array}{l}251 \text { (11 } \\
\text { missing) }\end{array}$ & $2(<1 \%)$ & $\begin{array}{c}\$ 0- \\
\$ 306,087\end{array}$ & $\$ 27,683$ & $\$ 35,216$ & 2,222 & $\$ 4,101$ & $\$ 8,979$ & $\$ 19,375$ & $\$ 31,384$ & $\$ 55,182$ \\
\hline \multirow{4}{*}{$\begin{array}{c}\text { Case } \\
\text { Dismissal } \\
\text { After } \\
\text { Confirmation }\end{array}$} & Secured & $\mid \begin{array}{c}300(1 \\
\text { missing) }\end{array}$ & $27(9 \%)$ & $\begin{array}{c}\$ 0- \\
\$ 84,619\end{array}$ & $\$ 10,387$ & $\$ 11,575$ & 688 & $\$ 403$ & $\$ 2,956$ & $\$ 7,644$ & $\$ 13,515$ & $\$ 22,028$ \\
\hline & Priority & $\begin{array}{c}300(1 \\
\text { missing) }\end{array}$ & $\begin{array}{c}177 \\
(59 \%)\end{array}$ & $\begin{array}{c}\$ 0- \\
\$ 83,522\end{array}$ & $\$ 1,513$ & $\$ 5,789$ & 334 & $\$ 0$ & $\$ 0$ & $\$ 0$ & $\$ 1,077$ & $\$ 3,846$ \\
\hline & General & 299 (2 $)$ & $23(8 \%)$ & $\begin{array}{c}\$ 0- \\
\$ 144,611\end{array}$ & $\$ 7,645$ & $\$ 13,182$ & 762 & $\$ 137$ & $\$ 1,605$ & $\$ 5,072$ & $\$ 8,550$ & $\$ 16,202$ \\
\hline & Total & $\begin{array}{c}298 \text { (3 } \\
\text { missing) }\end{array}$ & $1(<1 \%)$ & $\begin{array}{c}\$ 0- \\
\$ 154,328\end{array}$ & $\$ 21,338$ & $\$ 21,946$ & 1,271 & $\$ 5,643$ & $\$ 8,977$ & $\$ 14,373$ & $\$ 25,780$ & $\$ 43,644$ \\
\hline \multirow{4}{*}{$\begin{array}{c}\text { Case } \\
\text { Dismissed } \\
\text { Before } \\
\text { Confirmation }\end{array}$} & Secured & $\begin{array}{c}151 \text { (3 } \\
\text { missing) }\end{array}$ & $\begin{array}{c}50 \\
(33 \%)\end{array}$ & $\begin{array}{c}\$ 0- \\
\$ 376,577\end{array}$ & $\$ 13,228$ & $\$ 35,596$ & 2,896 & $\$ 0$ & $\$ 0$ & $\$ 3,673$ & $\$ 13,812$ & $\$ 26,584$ \\
\hline & Priority & $\begin{array}{c}149 \text { (5 } \\
\text { missing) }\end{array}$ & $\begin{array}{c}113 \\
(74 \%)\end{array}$ & $\begin{array}{c}\$ 0- \\
\$ 115,406\end{array}$ & $\$ 2880$ & $\$ 11,725$ & 960 & $\$ 0$ & $\$ 0$ & \$o & $\$ 0$ & $\$ 5,860$ \\
\hline & General & $\begin{array}{c}148(6 \\
\text { missing })\end{array}$ & $\begin{array}{c}46 \\
(30 \%)\end{array}$ & $\begin{array}{c}\$ 0- \\
\$ 131,676\end{array}$ & $\$ 7590$ & $\$ 19,069$ & 1,567 & $\$ 0$ & $\$ 0$ & $\$ 1,180$ & $\$ 6,138$ & $\$ 16,000$ \\
\hline & Total & $\begin{array}{c}146(8 \\
\text { missing })\end{array}$ & $\begin{array}{c}27 \\
(18 \%)\end{array}$ & $\begin{array}{c}\$ 0 \\
\$ 432,084\end{array}$ & $\$ 24,451$ & $\$ 47,879$ & 3,962 & $\$ 0$ & $\$ 1,250$ & $\$ 9,386$ & $\$ 24,712$ & $\$ 56,667$ \\
\hline \multirow{4}{*}{$\begin{array}{c}\text { Case } \\
\text { Converted } \\
\text { After } \\
\text { Confirmation }\end{array}$} & Secured & $\begin{array}{c}54(0 \\
\text { missing }\end{array}$ & $3(6 \%)$ & $\begin{array}{c}\$ 0- \\
\$ 45,296\end{array}$ & $\$ 12,821$ & $\$ 12,361$ & 1,682 & $\$ 687$ & $\$ 4,053$ & $\$ 8,598$ & $\$ 19,177$ & $\$ 34,483$ \\
\hline & Priority & $\begin{array}{c}54(0 \\
\text { missing) }\end{array}$ & $\begin{array}{c}24 \\
(44 \%)\end{array}$ & $\begin{array}{c}\$ 0- \\
\$ 14,635\end{array}$ & $\$ 1,555$ & $\$ 2,997$ & 407 & $\$ 0$ & $\$ 0$ & $\$ 127$ & $\$ 1,924$ & $\$ 5,221$ \\
\hline & General & $\begin{array}{c}54(0 \\
\text { missing) }\end{array}$ & $0(0 \%)$ & $\begin{array}{c}\$ 0- \\
\$ 122,864\end{array}$ & $\$ 11,431$ & $\$ 17,954$ & 2,443 & $\$ 1452$ & $\$ 4,600$ & $\$ 7,170$ & $\$ 11,457$ & $\$ 18,795$ \\
\hline & Total & $\begin{array}{c}54(0 \\
\text { missing) }\end{array}$ & $0(0 \%)$ & $\begin{array}{c}\$ 0- \\
\$ 137,568\end{array}$ & $\$ 25,824$ & $\$ 22,961$ & 3,124 & $\$ 6,643$ & $\$ 10,826$ & $\$ 21,230$ & $\$ 30,923$ & $\$ 50,090$ \\
\hline \multirow{4}{*}{$\begin{array}{c}\text { Case } \\
\text { Converted } \\
\text { Before } \\
\text { Confirmation }\end{array}$} & Secured & $\begin{array}{c}23(0 \\
\text { missing) }\end{array}$ & $\stackrel{4}{(17.4 \%)}$ & $\begin{array}{c}\$ 0- \\
\$ 35,412\end{array}$ & $\$ 10,298$ & $\$ 9,939$ & 2,073 & $\$ 0$ & $\$ 893$ & $\$ 8,117$ & $\$ 14,776$ & $\$ 27,980$ \\
\hline & Priority & $\begin{array}{c}23(0 \\
\text { missing) }\end{array}$ & $\begin{array}{c}11 \\
(48 \%)\end{array}$ & $\begin{array}{c}\$ 0- \\
\$ 43,953\end{array}$ & $\$ 4,409$ & $\$ 10,946$ & 2,282 & $\$ 0$ & $\$ 0$ & $\$ 25$ & $\$ 2,360$ & $\$ 24,056$ \\
\hline & General & $\begin{array}{c}23(0 \\
\text { missing) }\end{array}$ & $3(13 \%)$ & $\begin{array}{c}\$ 0- \\
\$ 31,231\end{array}$ & $\$ 7,514$ & $\$ 9,695$ & 2,067 & $\$ 0$ & $\$ 271$ & $\$ 3,269$ & $\$ 12,696$ & $\$ 27,107$ \\
\hline & Total & $\begin{array}{c}23(0 \\
\text { missing })\end{array}$ & $2(8 \%)$ & $\begin{array}{c}\$ 0- \\
\$ 69,817\end{array}$ & $\$ 21,959$ & $\$ 18,779$ & 4,003 & $\$ 371$ & $\$ 8,252$ & $\$ 18,204$ & $\$ 31,274$ & $\$ 56,461$ \\
\hline
\end{tabular}

Finally, we found no significant relation between home ownership - mortgage debt - and case outcome. The absence of significance exists not only as between cases dismissed or converted before confirmation, cases dismissed or converted after confirmation, and completed

92. Assumption-free analyses are used (Kruskal-Wallis and median test) because of the non-normality of these distributions. 
cases ${ }^{93}$ but also as between all dismissed or converted cases and completed cases. ${ }^{94}$

\section{Debtor and Household Debt-Income Ratios ${ }^{95}$}

Debtors whose cases were dismissed or converted before confirmation $^{96}$ had significantly ${ }^{97}$ lower personal debt-income ratios than debtors whose cases were dismissed or converted after confirmation ${ }^{98}$ and debtors who obtained a discharge. ${ }^{99}$ Likewise, debtors whose cases were dismissed or converted before confirmation 100 had significantly $^{101}$ lower household debt-income ratios than debtors whose cases were dismissed or converted after confirmation ${ }^{102}$ and debtors who obtained a discharge. ${ }^{103}$ The difference between the median debtor debt-income ratio in cases dismissed or converted before confirmation and in cases in which the court confirmed a plan was modest but significant. As shown in Table 27 below, the median debtor debtincome ratio in cases dismissed or converted before confirmation was 0.675 , while it was 1.02 in cases dismissed or converted after confirmation and 1.05 in cases in which the debtor obtained a discharge. Additionally, the median household debt-income ratio in cases dismissed or converted before confirmation was 0.582 , compared to 0.920 in cases dismissed or converted after confirmation and 0.918 in completed cases. Post hoc statistical analyses did not indicate any significant differences in the debt-income ratios of debtors who completed their plans and of debtors whose cases were dismissed or converted after confirmation. ${ }^{104}$

93. $\chi^{2}(4, \mathrm{~N}=794)=.664, \mathrm{p}=.956$.

94. $\chi^{2}(1, \mathrm{~N}=794)=.004, \mathrm{p}=.951$.

95. Debt was computed by totaling allowed claims in the case, excluding long-term mortgages that would remain to be paid after completion of the plan. (It may not always have been possible to identify long-term mortgage debts from the name of the creditor, so some may be included in the calculations.) Annual net income was computed by multiplying by twelve the net monthly incomes listed in the debtors' schedules.

96. Scheffe' test, $M=1.10(S E M=.103)$

97. $F(2,733)=3.96, p=.020,0^{2}=.011$.

98. Scheffe' test, $M=1.39($ SEM $=.069)$.

99. Scheffe' test, $M=1.46(S E M=.082)$.

100. Scheffe' test, $M=0.89(S E M=.073)$.

101. $\quad F(2,733)=3.89, p=.021,0^{2}=.010$.

102. Scheffe' test, $M=1.12($ SEM $=.048)$.

103. Scheffe' test, $M=1.11(S E M=.058)$.

104. Scheffe' tests at an alpha level of .05. Sullivan, Warren, and Westbrook found the non-mortgage debt-income ratios of Chapter 7 debtors were statistically indistinguishable from those of Chapter 13 debtors. Teresa A. Sullivan, Elizabeth Warren \& Jay L. Westbrook, As We Forgive Our Debtors: Bankruptcy and Consumer Credit IN AMErica 238-39 and Tables 13.2, 13.3 (1999); Teresa A. Sullivan, Elizabeth Warren \& Jay L. Westbrook, Laws, Models, and Real People: Choice of Chapter in Personal Bankruptcy, 13 LAW \& Soc. INQUIRY 661 (1988). Thus, ability to repay does not distin- 
In sum, the debtors in greatest need of debt relief were more likely to attain confirmation of a plan, while debtors with less need were less likely to do so. These data further support the inference that debtors who are most reluctant to file, and so have higher debt-income ratios by the time they file, are more likely to have the determination to complete a plan. As discussed above, most cases dismissed before confirmation are dismissed at the debtor's insistence or because the debtor did not file a plan or other required papers. Further, as discussed below, ${ }^{105}$ debtors whose cases were dismissed before confirmation were more likely to file again. Together with these facts, the lower debt-income ratios of debtors whose cases were dismissed before confirmation suggests that some of these debtors may have used the system for reasons other than obtaining relief from their debts, for example, simply to obtain temporary protection of the automatic stay.

guish debtors who choose to file under Chapter 13 from those who file under Chapter 7. The Chapter 13 Project findings here that debt-income ratios of Chapter 13 debtors who completed their plans were significantly higher than debtors who did not attain a discharge suggests an inverse relation between ability to repay and discharge in Chapter 13.

105. See infra notes 115-18 and accompanying text and Tables 29 and 30. 
TABLE 27. DEBTOR AND HOUSEHOLD DEBT-ANNUAL NET INCOME RATIOS AND CASE OUTCOME

\begin{tabular}{|c|c|c|c|c|c|c|c|c|c|c|}
\hline & & & $N$ & Range & Mean & $S D$ & SEM & $25 \%$ & Median & $75 \%$ \\
\hline \multirow{2}{*}{$\begin{array}{c}\text { Cases } \\
\text { Dismissed or } \\
\text { Converted } \\
\text { Before } \\
\text { Confirmation }\end{array}$} & Petitioner & $\begin{array}{c}\text { Annual Net } \\
\text { Income - } \\
\text { Debt Ratio }\end{array}$ & $\begin{array}{r}155(22 \\
\text { missing) }\end{array}$ & $0-25.17^{106}$ & 1.10 & 1.24 & .103 & 187 & .675 & 1.65 \\
\hline & Household & $\begin{array}{c}\text { Annual Net } \\
\text { Income - } \\
\text { Debt Ratio }\end{array}$ & \begin{tabular}{c|}
154 (23 \\
missing) \\
\end{tabular} & $0-25.17^{107}$ & 0.89 & 1.03 & $\mid .073$ & .106 & .582 & 1.28 \\
\hline \multirow{2}{*}{$\begin{array}{c}\text { Cases } \\
\text { Dismissed or } \\
\text { Converted } \\
\text { after } \\
\text { Confirmation }\end{array}$} & Petitioner & $\begin{array}{l}\text { Annual Net } \\
\text { Income - } \\
\text { Debt Ratio }\end{array}$ & $\begin{array}{l}345(10 \\
\text { missing) }\end{array}$ & $0-13.06^{108}$ & 1.39 & 1.22 & .069 & .646 & 1.02 & 1.64 \\
\hline & Household & $\begin{array}{l}\text { Annual Net } \\
\text { Income - } \\
\text { Debt Ratio }\end{array}$ & $\begin{array}{c}348(7 \\
\text { missing) }\end{array}$ & $0-13.06^{109}$ & 1.12 & .895 & .048 & .566 & .920 & 1.34 \\
\hline \multirow{2}{*}{$\begin{array}{l}\text { Cases in } \\
\text { which } \\
\text { debtor } \\
\text { obtained } \\
\text { discharge }\end{array}$} & Petitioner & $\begin{array}{l}\text { Annual Net } \\
\text { Income - } \\
\text { Debt Ratio }\end{array}$ & $\begin{array}{c}242(20 \\
\text { missing) }\end{array}$ & $0-12.73^{110}$ & 1.46 & 1.37 & 0.082 & 0.589 & 1.05 & 1.82 \\
\hline & Household & \begin{tabular}{|c|} 
Annual Net \\
Income - \\
Debt Ratio
\end{tabular} & $\begin{array}{l}243 \text { (19 } \\
\text { missing) }\end{array}$ & $0 \cdot 12.73^{111}$ & 1.11 & .817 & .058 & .499 & .918 & 1.55 \\
\hline
\end{tabular}

\section{B. Other Bankruptcy Filings and Case Outcome}

In this section, we discuss the relation between other bankruptcy filings and case outcome. As discussed in Part IV.C. above, among the most remarkable findings of the Project is the very high numbers of repeat Chapter 13 filers. At least one-half of the sample debtors had filed at least one other case: the available data show that $30 \%$ had filed one other case, $10 \%$ had filed two other cases, and $10 \%$ had filed three or more cases in addition to the sample case. ${ }^{112}$

Debtors who filed bankruptcy for the first time in the sample case were significantly more likely to complete their plans than debtors who had filed one or more previous cases. Conversely, sample debtors whose cases were dismissed were more likely to have filed previously. ${ }^{113}$ As shown in Table 28 below, of the debtors who had not filed

106. All ratios $>8.77(M+3 S D)$ were excluded from subsequent descriptive and inferential procedures.

107. All ratios $>8.00(M+3 S D)$ were excluded from subsequent descriptive and inferential procedures.

108. All ratios $>5.54(M+3 S D)$ were excluded from subsequent descriptive and inferential procedures.

109. All ratios $>4.46(M+3 S D)$ were excluded from subsequent descriptive and inferential procedures.

110. All ratios $>6.84(M+3 S D)$ were excluded from subsequent descriptive and inferential procedures.

111. All ratios $>5.07(M+3 S D)$ were excluded from subsequent descriptive and inferential procedures.

112. See supra notes 61-62 and accompanying text and Figure 3 and Table 11.

113. Previous Filings and Plan Completion/Chi-square Analysis 
a previous case, $38 \%$ successfully completed their plans, compared to a completion rate of $22.5 \%$ for debtors who had filed one previous case. The completion rate plummeted to $14 \%$ for debtors who had filed two or more cases before the sample case. ${ }^{114}$

\section{TABLE 28. PREVIOUS FILINGS AND CASE OUTCOME, BY NUMBER OF PREVIOUS FILINGS}

\begin{tabular}{|l|c|c|c|c|}
\hline $\begin{array}{l}\text { \# of Previous } \\
\text { Filings }\end{array}$ & $\begin{array}{c}\text { \# of } \\
\text { Debtors }\end{array}$ & $\begin{array}{c}\text { \% of All } \\
\text { Debtors }\end{array}$ & $\begin{array}{c}\text { Debtor } \\
\text { Obtained } \\
\text { Discharge }\end{array}$ & $\begin{array}{c}\text { \% of All } \\
\text { Debtors }\end{array}$ \\
\hline 0 & 560 & $70.4 \%$ & 213 & $38.0 \%$ \\
\hline 1 & 178 & $22.4 \%$ & 40 & $22.5 \%$ \\
\hline $2-5$ & 57 & $7.2 \%$ & 8 & $14.0 \%$ \\
\hline All cases & 795 & $100.0 \%$ & 262 & $33.0 \%$ \\
\hline
\end{tabular}

A chi-square analysis confirms the significant relation between outcome in the sample case and whether the debtor had any previous filings. ${ }^{115}$ As reflected in Table 29, only $19 \%$ of debtors who obtained a discharge in the sample case had a record of any previous filings. In other words, the sample case was the first case ${ }^{116}$ filed for $81 \%$ of the debtors who obtained a discharge in the sample case. By contrast, $30 \%$ of sample debtors whose current case was dismissed or converted

\begin{tabular}{|l|c|c|c|c|}
\hline \hline \multicolumn{3}{|c|}{ Record of Previous Filing and Current Case Outcome } & \\
\hline \multirow{2}{*}{} & \multicolumn{2}{|c|}{ Outcome of Current Case } & Total \\
\cline { 3 - 5 } & & Discharge & $\begin{array}{c}\text { No } \\
\text { discharge }\end{array}$ & \\
\hline \multirow{2}{*}{ Any Previous Filings? } & No & 213 & 347 & 560 \\
\cline { 2 - 5 } & Yes & 49 & 186 & 235 \\
\cline { 2 - 5 } Total & & 262 & 533 & 795 \\
\hline
\end{tabular}

$\chi^{2}(1, N=795)=22.12, p<.001$

114. Consistent with these findings, Professor Lown found a discharge rate of only 2.9\% for Chapter 13 debtors filing for relief in Utah in 1997 when they had filed three other cases within two years or four or more cases within twenty years (defining such debtors as "serial filers" and "possible abusers"). She further found that males and females filing individually were nearly $50 \%$ less likely to be abusers than joint filers, that "serial filers had higher secured debt but lower unsecured debt than" other repeat filers, and that "serial filers reported higher monthly income than" the other debtors. Jean $M$. Lown, Serial Bankruptcy: A 20-Year Study of Utah Filers, 25 AM. BankR. INST. J. 24, 2425, 68-69 (Feb. 2006). Cf. Scott F. Norberg, Consumer Bankruptcy's New Clothes: An Empirical Study of Discharge and Debt Collection in Chapter 13, 7 Am. BaNkR. INST. L. REv. 415, 450 (1999) (study of seventy-one chapter 13 cases filed in the Southern District of Mississippi between 1992 and 1998 finding that debtors who had filed single prior case obtained a discharge at a greater rate than first-time filers).

115. $\chi^{2}(4, N=794)=45.99, p \leq .01$.

116. This statement must be qualified by the likelihood that some of the sample debtors had filed a case earlier than recorded in the PACER system or in another jurisdiction. 
after confirmation and $44 \%$ of debtors whose current case was dismissed or converted before confirmation had a record of at least one previous filing. TABLE 29. PREVIOUS FILINGS AND CASE OUTCOME, BY
CASE OUTCOME

\begin{tabular}{|c|c|c|c|}
\hline & \multicolumn{2}{|c|}{ Any Previous Filings? } & Total \\
\hline $\begin{array}{l}\text { Close Code for the } \\
\text { Current Case } \\
\text { discharged } \\
\text { dismissed or converted } \\
\text { after confirmation } \\
\text { dismissed or converted } \\
\text { before confirmation } \\
\text { Total }\end{array}$ & $\begin{array}{c}\text { No } \\
213(81 \%) \\
248(70 \%) \\
\\
99(56 \%) \\
560\end{array}$ & $\begin{array}{c}\text { Yes } \\
49(19 \%) \\
107(30 \%) \\
78(44 \%) \\
234\end{array}$ & $\begin{array}{r}262 \\
355 \\
\\
177 \\
794\end{array}$ \\
\hline
\end{tabular}

Finally, the data regarding filings after discharge in the sample case confirm the relation between multiple filings and case outcome. Chi-square analysis again reveals a significant relation between outcome in the sample case and whether the debtor had any subsequent filings. ${ }^{117}$ As shown in Table 30 below, $15 \%$ of debtors who obtained a discharge in the sample case had a record of any subsequent filings. In other words, $85 \%$ of the debtors who obtained a discharge in the sample case did not return to bankruptcy. ${ }^{118}$ In contrast, $41 \%$ of sample debtors whose current case was dismissed after confirmation and $49 \%$ of debtors whose current case was dismissed before confirmation filed at least one more case.

TABLE 30. CASE OUTCOME AND SUBSEQUENT FILINGS, BY CASE OUTCOME

\begin{tabular}{|l|r|r|r|}
\hline & \multicolumn{2}{|c|}{ Any Subsequent Filings? } & Total \\
\hline Close Code for the Current Case & No & Yes & \\
discharged & $223(85 \%)$ & $39(15 \%)$ & 262 \\
dismissed after confirmation & $177(59 \%)$ & $123(41 \%)$ & 300 \\
dismissed before confirmation & $78(51 \%)$ & $76(49 \%)$ & 154 \\
converted after confirmation & $41(75 \%)$ & $13(25 \%)$ & 54 \\
converted before confirmation & $12(55 \%)$ & $10(45 \%)$ & 22 \\
Total & 531 & 261 & 792 \\
\hline
\end{tabular}

In sum, the statistical analyses reported in this section indicate that with each successive filing, the debtor is less likely to complete a

117. $\chi^{2}(4, N=792)=69.73, p \leq .01$.

118. Again, this statement must be qualified by the likelihood that some of these current debtors had filed a case after completion of the search of records in the PACER system or in another jurisdiction. 
plan, and more likely to have sought relief without the intent or ability to consummate a plan.

\section{Chapter 13 Plan Provisions and Case Outcome \\ 1. Plan Payments and Debtor and Household Retained Income}

Table 31 below reports on the following: (1) the debtors' monthly plan payments - the dollar amounts that the debtors proposed to devote to payment of creditor claims under their plans (excluding any payments to be made to creditors outside the plan), and (2) the debtors' "retained income" - the monthly income that the debtors, and their households, would retain after making their plan payments, to cover (a) current living expenses and (b) any payments to creditors outside the plan. ${ }^{119}$

Debtors' proposed monthly payments to creditors under their plans ranged from minimal $-\$ 24$ per month - to very large $-\$ 3,060$ per month-with a mean and median of $\$ 400$ and $\$ 310$, respectively.

The mean and median amounts of income retained by individual debtors for payment of current expenses and any payments outside the plan were very modest, $\$ 988$ and $\$ 875$, respectively. For debtor households, the mean and median amounts were only $\$ 1315$ and $\$ 1134$. Even at the 75 th percentile, the income retained for current living expenses was limited-\$1295 for individual debtors and $\$ 1709$ for debtor households.

The data indicate that a number of debtors proposed plans that were patently not feasible, that is, current living expenses and proposed payments to creditors exceeded household net income. There were 294 cases in which debtor or household net income minus current expenses and proposed payments to creditors was less than $\$ 0$. Indeed, in sixty-one of these cases, net income minus current expenses was less than $\$ 0$, meaning that, according to the debtor's proposed budget, there was no income available to make payments to creditors. In a few cases $(\mathrm{N}=8)$, the debtors proposed to make payments to creditors that exceeded their net incomes. In other words, these debtors did not budget any income to cover current expenses after making their plan payments. Debtor retained income ranged as low as $\$ 1,818$, and household retained income ranged as low as $-\$ 508$.

119. In addition to reporting gross and net debtor and household income, see Schedule I, Chapter 13 debtors must submit a budget of current expenses, which includes all expenses, from rent or mortgage to utilities and insurance, and excludes plan payments, see Schedule J. See supra note 79. "Retained income" was calculated by subtracting the proposed plan payments from net income as reported in Schedule I. 
TABLE 31. PROPOSED PLAN PAYMENTS AND RETAINED INCOME

\begin{tabular}{|l|c|c|c|c|c|c|c|c|}
\hline & $N$ & Range & Mean & SD & SEM & $25 \%$ & Median & $75 \%$ \\
\hline $\begin{array}{l}\text { Proposed } \\
\text { monthly } \\
\text { payments }\end{array}$ & $\begin{array}{c}732 \\
63 \text { cases } \\
\text { missing })\end{array}$ & $\$ 24-\$ 3060^{120}$ & $\$ 400$ & $\$ 294$ & 11.0 & $\$ 182$ & $\$ 310$ & $\$ 535$ \\
\hline $\begin{array}{l}\text { Debtor } \\
\text { retained } \\
\text { income }\end{array}$ & $\begin{array}{c}729 \\
\left(\begin{array}{c}76 \text { cases } \\
\text { missing })\end{array}\right.\end{array}$ & $<-\$ 1818>-\$ 39600^{121}$ & $\$ 988$ & $\$ 706$ & 26.2 & $\$ 573$ & $\$ 875$ & $\$ 1,295$ \\
\hline $\begin{array}{l}\text { Household } \\
\text { retained } \\
\text { income }\end{array}$ & $\begin{array}{c}726 \\
(69 \text { cases } \\
\text { missing })\end{array}$ & $<-\$ 508>-\$ 39600^{122}$ & $\$ 1,315$ & $\$ 808$ & 30.1 & $\$ 759$ & $\$ 1,134$ & $\$ 1,709$ \\
\hline
\end{tabular}

As to be expected, there was no significant difference in case outcome based on the amounts that the debtors dedicated to repayment of creditor claims; standing alone, and without regard to net income, current expenses, or retained income, the amount that debtors proposed to pay to pre-bankruptcy creditors was not significantly related to whether the debtor obtained a discharge. ${ }^{123}$

Unexpectedly, the data also indicate no significant relationship between debtor retained income and case outcome. Individual debtors who retained more income to pay current living expenses ${ }^{124}$ were not more likely to complete their plans. ${ }^{125}$ Indeed, 30\% (91 of 294) of the debtors whose budgets indicated less income than living expenses plus payments to creditors actually completed their plans. ${ }^{126}$ This is only slightly lower than the overall discharge rate of $33 \%$. Only $15 \%$ (45 of 294) of these cases were dismissed or converted before confirmation; in $85 \%$ of the cases, the court confirmed the debtor's facially infeasible plan. As with the amount of proposed plan payments, then, the amount of debtor retained income, standing alone and without regard to the debtor's standard of living, did not bear significantly on a debtor's completion of a plan.

120. All payment amounts $>\$ 1596(M+3 S D)$ were excluded from subsequent descriptive and inferential procedures.

121. All income amounts > $\$ 6346(M+3 S D)$ were excluded from subsequent descriptive and inferential procedures.

122. All income amounts $>\$ 6822(M+3 S D)$ were excluded from subsequent descriptive and inferential procedures.

123. Completed cases $(n=246), M=\$ 382(S E M=18.9)$ versus dismissed cases $(n=$ $471), M=\$ 408(S E M=13.5) ; t(714)=1.13, p=.258(n s)$.

124. By the same token, the debtor may not reserve more than a reasonable amount of income for payment of living expenses unless the plan will pay unsecured creditors in full. 11 U.S.C.A. § 1326(b)(1) (1994) (pre-BAPCPA) (stating that all of a debtor's disposable income must be used to make payments under plan).

125. Completed cases $(n=252), M=\$ 1022(S E M=45.8)$ versus dismissed cases $(n=$ 473), $M=\$ 969(S E M=31.9) ; t(723)=0.96, p=.339(n s)$.

126. Even more surprising, two of the eight debtors whose budgets showed net income that was less than their plan payments alone completed their plan and obtained a discharge. 
The data regarding debtors' infeasible budgets support a number of inferences. They confirm that some courts and Chapter 13 trustees do not always carefully screen plans for confirmation based on feasibility, at least when there is no creditor objection to confirmation. And given the plan completion rate for debtors whose plans were apparently not feasible, the lack of screening for feasibility appears warranted. The data also may mean that many debtors (and not just those whose plans are not feasible) understate income and overstate expenses. Alternatively, the data are reason to conclude that some debtors are in bankruptcy because they lack basic money management skills, such as constructing a budget, although the debtor's attorney might be expected to help address the problem. Alternatively, or in addition, perhaps the data are not reliable as we have used them here; combining numbers from different sources - Schedules I and $J$, on the one hand, and the debtor's plan, on the other - may have produced inaccuracies.

Finally, while individual debtor retained income was not significantly related to case outcome, as reported in Table 32 below, household retained income was significantly related to case outcome. ${ }^{127}$ These findings parallel the findings above regarding the relation between case outcome and debtor and household annual income. ${ }^{128}$

\section{TABLE 32. HOUSEHOLD RETAINED INCOME IN COMPLETED AND DISMISSED CASES}

\begin{tabular}{|c|c|c|c|c|c|c|c|c|}
\hline & $\mathbf{N}$ & Range & Mean & $\mathrm{SD}$ & SEM & $25 \%$ & Median & $75 \%$ \\
\hline Discharged & 249 & $-<\$ 508>-\$ 3869$ & $\$ 1,407$ & $\$ 751$ & 47.6 & $\$ 842$ & $\$ 1,314$ & $\$ 1,800$ \\
\hline $\begin{array}{l}\text { Dismissed } \\
\text { After } \\
\text { Confirmation }\end{array}$ & 282 & $-<250>-\$ 5037$ & $\$ 1,149$ & $\$ 718.93$ & 42.8 & $\$ 687$ & $\$ 977$ & $\$ 1,505$ \\
\hline $\begin{array}{l}\text { Dismissed } \\
\text { Before } \\
\text { Confirmation }\end{array}$ & 120 & $-<157>-\$ 4377$ & $\$ 1,452$ & $\$ 919.34$ & 83.9 & $\$ 767$ & $\$ 1,243$ & $\$ 2,001$ \\
\hline $\begin{array}{l}\text { Converted } \\
\text { After } \\
\text { Confirmation }\end{array}$ & 53 & $\$ 150-\$ 5804$ & $\$ 1,497$ & $\$ 1,090$ & 149.7 & $\$ 747$ & $\$ 1,184$ & $\$ 1,936$ \\
\hline $\begin{array}{l}\text { Converted } \\
\text { Before } \\
\text { Confirmation }\end{array}$ & 18 & $\$ 50-\$ 2956$ & $\$ 1,189$ & $\$ 733.72$ & 172.9 & $\$ 664$ & $\$ 994$ & $\$ 1,602$ \\
\hline ALL CASES & $\begin{array}{c}726(69 \\
\text { missing })\end{array}$ & $-<\$ 508>-\$ 39600^{129}$ & $\$ 1,315$ & $\$ 808.03$ & 30.1 & $\$ 758$ & $\$ 1,134$ & $\$ 1,709$ \\
\hline
\end{tabular}

127. Completed cases $(n=249), M=\$ 1407(S E M=47.6)$ versus dismissed cases $(n=$ $473), M=\$ 1266(S E M=38.3) ; t(720)=2.30, p=.026$.

128. See supra notes 79-84 and accompanying text and Table 25.

129. All income amounts $>\$ 6822(M+3 S D)$ were excluded from subsequent descriptive and inferential procedures. 


\section{Proposed Distributions to Unsecured Creditors}

The Bankruptcy Code does not mandate a minimum amount or percentage distribution that a Chapter 13 plan must provide to unsecured creditors. Generally, as long as the plan meets the best interests requirement ${ }^{130}$ and the debtor devotes all "disposable income" to the payment of unsecured claims, ${ }^{131}$ the percentage distribution is irrelevant. In practice, however, there reportedly has been considerable variation among districts regarding the level of repayment that Chapter 13 debtors propose. An earlier survey suggested that many debtors proposed plans that pay more than required by the best interests and disposable income tests because their attorneys advised them to do so in order to comply with judges' and trustees' expectations and thereby maintain economical, routinized practices. ${ }^{132}$

As reported in Table 33 below, the debtors in the sample cases proposed to pay from $0 \%$ to $100 \%$ of general unsecured claims. There were a large number of "missing cases" - 230 - in which there was no proposed distribution to unsecured creditors, including at least 94 cases in which the debtors proposed to make an unspecified, pro rata distribution to be determined at confirmation based on filed, allowed claims. As a result, the data reported here are not definitive. Excluding the "missing cases," the large majority of debtors proposed to pay either $100 \%$ or less than $26 \%$ of their unsecured debts. The modal proposed distribution was 100\%; 206 (31.2\%) of the debtors who proposed to pay a specified distribution to unsecured creditors proposed to pay 100 cents on the dollar. The large standard deviation - nearly $42 \%$ - reflects this wide variation in the proposed levels of repayment to general creditors.

\section{TABLE 33. PROPOSED DISTRIBUTIONS TO UNSECURED CREDITORS}

\begin{tabular}{|c|c|c|c|c|c|c|c|}
\hline $\mathrm{N}$ & Range & Mean & SD & SEM & $25 \%$ & Median & $75 \%$ \\
\hline 565 & $0 \%-100 \%$ & $48.76 \%$ & $41.71 \%$ & 1.75 & $10 \%$ & $25 \%$ & $100 \%$ \\
\hline
\end{tabular}

230 cases missing (including 94 cases in which plans provided for pro rata distribution to unsecured creditors); mode $=100 \%$ (206 cases $/ 36.5 \%$ )

As reported in Table 34 below, debtors in nearly $45 \%$ of the cases in which a distribution was reported proposed to pay no more than $25 \%$ of unsecured claims, while nearly $15 \%$ of the debtors, all in the

130. 11 U.S.C. $\S 1325(a)(4)$.

131. 11 U.S.C. $\$ 1322(a)(4)$.

132. See William C. Whitford, The Ideal of Individualized Justice: Consumer Bankruptcy as Consumer Protection, and Consumer Protection in Consumer Bankruptcy, 68 AM. BANkR. L.J. 397, 405-06 (1994); Jean Braucher, Lawyers and Consumer Bankruptcy: One Code, Many Cultures, 67 AM. BANKR. L.J. 501, 532 (1993). 
District of Maryland and the Southern District of Georgia, proposed to pay an unspecified, pro rata distribution to general creditors. ${ }^{133}$ Relatively few debtors - less than $10 \%$-proposed to pay between $26 \%$ and 99\%. Again, because of the large number of excluded cases, the figures reported here are necessarily tentative; the distributions in the excluded cases might have been anywhere between $0 \%$ and $100 \%$.

\section{TABLE 34. PROPOSED LEVELS OF REPAYMENT ON UNSECURED CLAIMS}

\begin{tabular}{|l|c|c|}
\hline proposed \% & $\mathrm{N}$ & $\%$ of cases \\
\hline pro-rata & 94 & $14.2 \%$ \\
\hline $0 \%-9 \%$ & 121 & $18.3 \%$ \\
\hline $10 \%-15 \%$ & 40 & $6.1 \%$ \\
\hline $16 \%-25 \%$ & 135 & $20.4 \%$ \\
\hline $26 \%-50 \%$ & 35 & $5.3 \%$ \\
\hline $51 \%-99 \%$ & 28 & $4.2 \%$ \\
\hline $100 \%$ & 206 & $31.2 \%$ \\
\hline TOTAL & 659 & $100 \%$ \\
\hline
\end{tabular}

Analysis of the proposed distributions to unsecured creditors (excluding pro rata distribution cases) between the districts in the study indicates a significant relation between district and the percentage distribution proposed in debtors' plans. ${ }^{134}$ Debtors in the Middle Dis-

133. There were 136 "missing cases" in which a proposed distribution to unsecured creditors could not be ascertained. However, in many of these cases, the proposed distribution was not in fact "missing;" rather, the debtor proposed a pro-rata distribution, with the distribution to be designated after the bar date for filing of claims. The following table breaks out the number of missing and pro-rata cases by district.

\begin{tabular}{|l|c|c|}
\hline District (number of cases) & $\begin{array}{c}\text { Number of pro-rata } \\
\text { distributions }\end{array}$ & $\begin{array}{c}\text { Number of cases missing } \\
\text { a proposed distribution }\end{array}$ \\
\hline MD (100) & 41 & 22 \\
\hline MDNC (100) & 0 & 8 \\
\hline MDTN (100) & 0 & 7 \\
\hline NDGA (165) & 0 & 22 \\
\hline SDGA (100) & 53 & 4 \\
\hline WDPA (100) & 0 & 22 \\
\hline WDTN (130) & 0 & 51 \\
\hline
\end{tabular}

134. $F(6,558)=3.91, p=.001,0^{2}=.040$. Professor Whitford likewise found large variations among districts as to proposed distributions to unsecured creditors in data he obtained from the National Association of Chapter 13 Trustees in 1993. See Whitford, 68 АM. BANKR. L.J. at 409-11, Table 2 (in survey of Chapter 13 trustees, $71 \%$ of whom responded, the percentage of confirmed plans proposing to pay $100 \%$ of unsecured claims ranged from $6 \%$ to $52 \%$; while the average proposed payout in less-than-100\% plans ranged from 13\% to 56\%). Accord Braucher, 67 AM. BANKR. L.J. at 532 (study of 
trict of North Carolina proposed to pay a significantly lower percentage of unsecured claims ${ }^{135}$ than debtors in the other districts. ${ }^{136}$

There was no statistically significant difference in the proposed percentage to be paid on unsecured debt by debtors in completed cases than by debtors in cases dismissed or converted either before or after confirmation. That is, the debtors who completed their plans and obtained a discharge did not propose to repay a significantly different percentage of general unsecured claims than debtors whose cases were dismissed or converted. ${ }^{137}$ These findings are counterintuitive and appear to contradict data collected in another survey. ${ }^{138}$ Perhaps the absence of a significant relationship between the percentage of unsecured claims to be paid under a plan and plan completion is explained by the fact that the bankruptcy courts in the study, unlike some other courts, generally did not expect or impose a fixed or minimum percentage of general claims that must be paid. As a result, most of the debtors in the sample cases were not faced with having to devote income to paying unsecured claims without regard to how much income was available after a reasonable forecast of a household budget. Table 35 reports on the percentages of unsecured debt that debtors proposed to pay in completed, dismissed, and converted cases.

practices in four districts, finding "floor" percentage of $100 \%$ in two, $25-33 \%$ in one, and $70 \%$ in another).

135. $(M=31.7 \%, S E M=4.28)$.

136. Also, debtors in the District of Maryland proposed to pay a significantly higher percentage on unsecured claims $(M=61.3 \%, S E M=6.75)$, however, this observation is based on only 37 of 100 cases.

137. Mann-Whitney $U=34135, z=-1.128, p=.259$; Kruskal-Wallis $\chi^{2}$ (4, $N=565)=6.872, p=.143$ ).

138. See Whitford, 68 Am. BANKR. L.J. at 410-12. See also Jean Braucher, An Empirical Study of Debtor Education in Bankruptcy: Impact on Chapter 13 Completion Not Shown, 9 Am. Bankr. Inst. L. REv. 557, 577-79 (2001). 


\section{TABLE 35. CASE OUTCOME AND PROPOSED DISTRIBUTIONS TO UNSECURED CREDITORS}

Completed Cases

\begin{tabular}{|l|c|c|c|c|c|c|c|}
\hline $\mathrm{N}$ & Range & Mean & SD & SEM & $25 \%$ & Median & $75 \%$ \\
\hline 196 & $0 \%-100 \%$ & $44.31 \%$ & $40.11 \%$ & 2.85 & $10 \%$ & $25 \%$ & $100 \%$ \\
\hline
\end{tabular}

mode $=100 \%(60$ cases $/ 30.6 \%)$

Dismissed Cases

\begin{tabular}{|l|c|c|c|c|c|c|c|}
\hline $\mathrm{N}$ & Range & Mean & SD & SEM & $25 \%$ & Median & $75 \%$ \\
\hline 369 & $0 \%-100 \%$ & $51.13 \%$ & $42.50 \%$ & 2.21 & $10 \%$ & $30 \%$ & $100 \%$ \\
\hline
\end{tabular}

mode $=100 \%(146$ cases $/ 39.6 \%)$

Converted Cases

\begin{tabular}{|l|c|c|c|c|c|c|c|}
\hline $\mathrm{N}$ & Range & Mean & SD & SEM & $25 \%$ & Median & $75 \%$ \\
\hline 54 & $0 \%-100 \%$ & $45.14 \%$ & $39.45 \%$ & 5.39 & $14.5 \%$ & $25 \%$ & $100 \%$ \\
\hline
\end{tabular}

\section{Proposed Plan Length}

As shown in Table 36 below, the debtors proposed plans with lengths ranging between 0 and 60 months, with a mean and median length of 52.43 and 60 months, respectively. ${ }^{139}$ At both the median and 75th percentile, the proposed length of debtor plans was 60 months. As further reported in Table 35, debtors in $60 \%$ of all cases in which a proposed plan length was reported proposed a 60-month plan, with nearly $70 \%$ proposing a plan of more than 48 months, and almost $80 \%$ proposing a plan of more than the statutory minimum of 36 months.

By law, before the BAPCPA, a Chapter 13 plan could not exceed 36 months except for "cause."140 The maximum plan length is 60 months, ${ }^{141}$ while the minimum is 36 months unless the debtor proposes to pay $100 \%$ of unsecured claims under a shorter plan. ${ }^{142}$ Thus, as reported in Tables 36 and 37 , it is notable that so many of the debtors proposed plans longer than 36 months and that the median and modal lengths of the sample debtors' plans were 60 months, or 24 months longer than the standard set out in the Bankruptcy Code. Indeed, the length of plans at the 25th percentile was 47 months, or

139. The sample cases in which the debtor proposed a plan of less than twelve months would appear to be mistakes. There are only eight of these cases, however, and they do not materially alter the analyses of these data.

140. 11 U.S.C.A. $\$ 1322$ (d) (1994) (pre-BAPCPA).

141. Id.

142. Id. 
nearly a year longer than the standard envisioned by the Bankruptcy Code. ${ }^{143}$

TABLE 36. PROPOSED LENGTH OF DEBTOR PLANS

\begin{tabular}{|l|c|c|c|c|c|c|c|}
\hline $\mathrm{N}$ & Range & Mean & SD & SEM & $25 \%$ & Median & $75 \%$ \\
\hline 587 (208 cases missing) & $\begin{array}{c}0-60 \\
\text { months }\end{array}$ & 52.43 & $\begin{array}{c}11.76 \\
\text { months }\end{array}$ & 0.486 & $\begin{array}{c}47 \\
\text { months }\end{array}$ & $\begin{array}{c}60 \\
\text { months }\end{array}$ & $\begin{array}{c}60 \\
\text { months }\end{array}$ \\
\hline
\end{tabular}

\begin{tabular}{|l|c|c|}
\hline Plan length & $\mathrm{N}$ & $\%$ \\
\hline $0-12$ months & 8 & $1.4 \%$ \\
\hline $13-24$ months & 6 & $1.0 \%$ \\
\hline $25-36$ months & 108 & $18.4 \%$ \\
\hline $37-48$ months & 55 & $9.4 \%$ \\
\hline $49-60$ months & 410 & $69.8 \%$ \\
\hline 60 months & 352 & $60.0 \%$ \\
\hline Missing ${ }^{144}$ & 208 & - \\
\hline
\end{tabular}

We hypothesized that debtors who proposed to make plan payments over a longer period of time would be more likely to complete their plans. By stretching payments to creditors over a longer term, in particular payments to secured creditors enabling the debtor to keep collateral, a debtor would be better able to afford them. ${ }^{145}$ The data do not, however, support this thesis. To the contrary, as reported in Table 37, debtors who completed their plans proposed significantly shorter plans ${ }^{146}$ than debtors who did not. ${ }^{147}$ Perhaps shorter plans reduce the risks of income and expense disruptions, or require correspondingly less discipline on the part of the debtor and so are more likely to be completed.

143. There were eight cases in which the debtor proposed a plan between 0 and 12 months. The cases proposing a plan of no length, and others of very short duration, may be errors, but because there are so few of these cases, any such errors do not affect the overall analyses.

144. Most of the missing cases are from NDGA because indefinite plan lengths (e.g., 36-60 months) were specified.

145. See Braucher, 9 AM. BANKR. InST. L. Rev. at 574-75 (stating that because the judges in all five districts covered by the study routinely confirmed five-year plans, it was not possible to determine the impact of the practice on plan completion).

146. $\mathrm{M}=51.31$ months, $\mathrm{SD}=11.25, \mathrm{SEM}=.789$.

147. $\mathrm{M}=53.45$ months, $\mathrm{SD}=11.07, \mathrm{SEM}=.568, \mathrm{t}\left(409.6^{*}\right)=2.196, \mathrm{p}=.029$. (The degrees of freedom in this test are reduced due to the significant inequality of variance revealed by Levene's Test, $\mathbf{F}=6.234, \mathbf{p}=.013$.) However, disposition was not significantly related to plan length, $F(2,515)=2.39, \mathrm{p}=.093$, eta^ $2=.009$, when cases in which the debtor obtained a discharge were separately compared to cases that were dismissed after confirmation and to cases that were dismissed before confirmation. 


\section{TABLE 37. PROPOSED LENGTH OF PLAN IN COMPLETED AND DISMISSED CASES}

\begin{tabular}{|l|c|c|c|c|c|c|c|c|c|}
\hline & $\mathrm{N}$ & Range & Mean & SD & SEM & $25 \%$ & Median & $75 \%$ & \\
\hline $\begin{array}{l}\text { Case Dismissed } \\
\text { Before Confirmation }\end{array}$ & 86 & $0-60$ & 50.24 & 17.09 & 1.84 & 36 & 60 & 60 & $\begin{array}{l}68 \text { cases } \\
\text { missing }\end{array}$ \\
\hline $\begin{array}{l}\text { Case Dismissed } \\
\text { After Confirmation }\end{array}$ & 231 & $12-60$ & 53.67 & 10.24 & 0.673 & 48 & 60 & 60 & $\begin{array}{l}70 \text { cases } \\
\text { missing }\end{array}$ \\
\hline $\begin{array}{l}\text { Case Converted } \\
\text { Before Confirmation }\end{array}$ & 18 & $36-60$ & 56.06 & 8.36 & 1.97 & 58 & 60 & 60 & $\begin{array}{l}5 \text { cases } \\
\text { missing }\end{array}$ \\
\hline $\begin{array}{l}\text { Case Converted } \\
\text { After Confirmation }\end{array}$ & 47 & $36-60$ & 53.66 & 9.16 & 1.33 & 48 & 60 & 60 & $\begin{array}{l}7 \text { cases } \\
\text { missing }\end{array}$ \\
\hline $\begin{array}{l}\text { Debtor Obtained } \\
\text { Discharge }\end{array}$ & 203 & $10-60$ & 51.4 & 11.23 & 0.788 & 36 & 60 & 60 & $\begin{array}{l}58 \text { cases } \\
\text { missing }\end{array}$ \\
\hline
\end{tabular}

There was no significant difference in the plan lengths proposed by individual filers ${ }^{148}$ compared to the plan lengths proposed by joint filers. ${ }^{149}$ As discussed elsewhere, joint filers completed their plans at a statistically greater rate than individual filers. ${ }^{150}$

An analysis of the variance in proposed length of plans revealed statistically significant differences between the proposed length of the debtor plans in the Middle District of North Carolina and the other six districts. ${ }^{151}$ As reported in Table 38 below, these post-hoc statistical comparisons revealed significantly shorter plans in the MDNC than in the other districts; $38 \%$ of the plans filed in that district had proposed plan lengths of 36 months. The post-hoc statistical comparisons also revealed significantly longer plans in both the MDTN and WDTN. The contribution of the MDTN to this effect was modest and specific; fifty-seven percent (57\%) of plans in the MDTN had proposed plan lengths of 60 months, the average proposed plan length in the MDTN was significantly longer than the average proposed plan length in the MDNC. Eighty-five percent (85\%) of the plans in the WDTN had proposed plan lengths of 60 months; ${ }^{152}$ the average proposed plan length in the WDTN was significantly longer than the proposed plan lengths in MD, MDNC, SDGA, and WDPA.

148. $\mathrm{M}=52.48$ months, $\mathrm{SD}=11.47, \mathrm{SEM}=.587$.

149. $\mathrm{M}=52.49$ months, $\mathrm{SD}=11.33, \mathrm{SEM}=.972, \mathrm{t}(516)=-.010, \mathrm{p}=.992$.

150. See supra notes 77-78 and accompanying text and Table 24 .

151. The data from this district were excluded from the analysis concerning districtlevel differences in proposed length of plans because only seven cases in NDGA included specific plan lengths.

152. $F(5,574)=8.00, p \leq .001,0^{2}=.065$. Levene's test for heterogeneity of variance was significant, $F(5,574)=11.14, p \# .001$; equality of the variance in proposed plan length should not be assumed across the districts. As a result, the post-hoc comparisons were completed using Dunnett's T3 test that does not assume equality of variances. 
TABLE 38. INTER-DISTRICT COMPARISONS OF PROPOSED LENGTH OF DEBTOR PLANS (IN MONTHS)

\begin{tabular}{|c|c|c|c|c|c|c|c|c|c|c|}
\hline District & $\mathbf{N}$ & Mean & SD & SEM & Mode & $10 \%$ & $25 \%$ & Median & $75 \%$ & $90 \%$ \\
\hline MD & 92 (8 missing) & 51.82 & 15.32 & 1.60 & 60 & 36 & 48 & 60 & 60 & 60 \\
\hline MDNC & 92 (8 missing) & 47.30 & 10.56 & 1.10 & 36 & 36 & 36 & 48 & 60 & 60 \\
\hline MDTN & 98 (2 missing) & 54.00 & 9.47 & 0.95 & 60 & 36 & 49 & 60 & 60 & 60 \\
\hline SDGA & 92 (8 missing) & 51.35 & 10.62 & 1.11 & 60 & 36 & 36 & 60 & 60 & 60 \\
\hline WDPA & 87 (13 missing) & 52.75 & 14.07 & 1.51 & 60 & 36 & 48 & 60 & 60 & 60 \\
\hline WDTN & 119 (11 missing) & 56.91 & 7.64 & 0.70 & 60 & 36 & 60 & 60 & 60 & 60 \\
\hline total & 587 (208 missing ${ }^{153}$ ) & & & & & & & & & \\
\hline
\end{tabular}

\section{Time Spent in Chapter 13}

Predictably, debtors who completed their plans spent significantly more time in Chapter 13 than debtors whose cases were dismissed or converted, either before or after confirmation; and debtors who achieved confirmation of a plan spent significantly more time in Chapter 13 than debtors whose cases were dismissed or converted before confirmation. ${ }^{154}$ Thus, as shown in Table 39 below, debtors who obtained a discharge spent on average more than twice as much time in Chapter 13 - 48.7 months - as debtors whose cases were dismissed or converted after confirmation -20.4 and 21.5 months, respectively. Debtors whose cases were dismissed or converted before confirmation of a plan spent an average of only 6.2 and 3.1 months, respectively, in Chapter 13.

The very short time spent in Chapter 13 by debtors whose cases were converted before confirmation may reflect that most conversions were sought by the debtor and did not require a court hearing. ${ }^{155}$ Likewise, the relatively short 25 th percentile, median, and 75 th percentiles (2.5, 3.4, 4.7 months), and longer mean (6.22 months), and high standard deviation (9.74) for cases dismissed before confirmation also suggest that most of these cases are voluntarily dismissed, with-

153. Most of the missing cases were from NDGA because the case records indicate plans of indefinite length (e.g., “36-60 months”).

154. The effect of disposition on time in Chapter 13 is confirmed by ANOVA. Disposition was significantly related to time spent in Chapter $13, F(4,765)=273.02, p \# .001$, $0^{2}=.588$. Scheffe' tests at an alpha level of .05 revealed three subsets-discharged cases spent the greatest amount of time in Chapter 13, cases either converted or dismissed after confirmation spent a moderate amount of time in Chapter 13, and cases either converted or dismissed before confirmation spent the least amount of time in Chapter 13.

155. See 11 U.S.C.A. $\$ 1307$ (a) (1994) (pre-BAPCPA) (permitting conversion by the debtor to Chapter 7 as a matter of right). 
out a hearing; ${ }^{156}$ or dismissed for failure to timely file a plan, schedules, or other required papers; or dismissed for failure to commence making timely payments under the plan. ${ }^{157}$ Such dismissals normally would occur more quickly than contested dismissals.

\section{TABLE 39. CASE DISPOSITION AND TIME IN CHAPTER 13 (IN MONTHS)}

\begin{tabular}{|l|c|c|c|c|c|c|c|c|}
\hline & $N$ & Range & Mean & $S D$ & $S E M$ & $25 \%$ & Median & $75 \%$ \\
\hline Discharged & $\begin{array}{c}259 \\
(3 \text { missing })\end{array}$ & $3.30-78.83$ & 48.66 & 15.65 & 0.972 & 39 & 50.7 & 61.5 \\
\hline $\begin{array}{l}\text { Dismissed After } \\
\text { Confirmation }\end{array}$ & $\begin{array}{c}290 \\
(11 \text { missing })\end{array}$ & $2.37-69.6$ & 20.41 & 14.54 & 0.854 & 10.5 & 16.4 & 25.7 \\
\hline $\begin{array}{l}\text { Dismissed Before } \\
\text { Confirmation }\end{array}$ & $\begin{array}{c}154 \\
(0 \text { missing })\end{array}$ & $0.4-59.6$ & 6.22 & 9.74 & 0.785 & 2.5 & 3.4 & 4.7 \\
\hline $\begin{array}{l}\text { Converted After } \\
\text { Confirmation }\end{array}$ & $\begin{array}{c}47 \\
(7 \text { missing })\end{array}$ & $4.0-61.7$ & 21.5 & 15.48 & 2.21 & 8.6 & 18 & 30.7 \\
\hline $\begin{array}{l}\text { Converted Before } \\
\text { Confirmation }\end{array}$ & $\begin{array}{c}20 \\
(3 \text { missing })\end{array}$ & $0.7-10.00$ & 3.12 & 1.95 & 0.435 & 2 & 2.75 & 3.4 \\
\hline $\begin{array}{c}770 \\
\text { ALL CASES }\end{array}$ & $0.4-78.8$ & 26.7 & 21.72 & 0.783 & 6.7 & 20.3 & 44.2 \\
\hline
\end{tabular}

Finally, according to Table 39 above, almost a quarter of debtors who achieved a Chapter 13 discharge completed their plans within 39 months, and $50 \%$ completed their plans within about 51 months. Fifty percent (50\%) of debtors who attained a discharge spent more than 51 months in Chapter 13. As further reported in Table 40 below, an analysis of the difference between actual time spent in Chapter 13 and proposed plan length by debtors who completed their plans indicates that $25 \%$ of these debtors spent at least five month less time in Chapter 13 than originally proposed, while $25 \%$ spent more than six months more than anticipated. On average, debtors who attained a discharge spent almost two months more in Chapter 13 than their plans proposed. These data suggest that policies permitting plan extensions would tend to promote plan completion. Finally, and predictably, there was a very large disparity between proposed plan length and actual time spent in Chapter 13 by debtors who did not complete their plans.

156. See 11 U.S.C. $\$ 1307$ (b) (1994) (pre-BAPCPA) (permitting the debtor to dismiss as a matter of right, unless the case has previously been converted from another chapter).

157. See 11 U.S.C. $\S 1307(c)(3)$, (9), (10) (1994) (pre-BAPCPA). 
TABLE 40. CASE DISPOSITION AND DISPARITY BETWEEN PROPOSED PLAN LENGTH AND ACTUAL TIME IN CHAPTER 13 (IN MONTHS)

\begin{tabular}{|l|c|c|c|c|c|c|c|c|}
\hline & $N$ & Range & Mean & $S D$ & $S E M$ & $25 \%$ & Median & $75 \%$ \\
\hline Discharged & $\begin{array}{c}201 \\
(61 \text { missing })\end{array}$ & $-54.6^{*}-30.5$ & -1.04 & 14.74 & 1.04 & -5.02 & 1.97 & 6.48 \\
\hline All Cases & $\begin{array}{c}559 \\
(236 \text { missing })\end{array}$ & $-59.6-30.5$ & -23.8 & 23.94 & 1.01 & -46.03 & -25.33 & -0.17 \\
\hline
\end{tabular}

\section{Other VARIABLES}

Countless variables bear on case outcomes in Chapter 13 that we do not consider in this paper. Other, more targeted studies, have examined several other factors. In her study of the impact of debtor education on case outcomes in Chapter 13, Professor Jean Braucher found that debtor education did not have a positive effect on case outcome, while routine use of wage orders and amount of attorney fees had a positive impact on case completion. ${ }^{158}$ Another study, by Michael Catrett, found that Chapter 13 cases filed in the Houston Division of the Southern District of Texas on or the day before "foreclosure day" were less likely to result in discharge than cases filed at other times of the month. ${ }^{159}$ Gordon Bermant has examined the effect of making ongoing mortgage payments through the plan on plan completion, hypothesizing that the practice promotes plan completion but finding the data inconclusive. ${ }^{160}$

\section{DEBT COLLECTION IN CHAPTER 13}

This Part considers the amounts and types of claims paid by debtors in the Chapter 13 system. First, we report and assess data collected by the Executive Office for United States Trustees (EOUST) and the Administrative Office of the Courts (AO) (for trustees in North

158. Braucher, 9 AM. BANKR. INST. L. REv. at 577-79.

159. Michael Catrett, Bankruptcy by the Numbers, A Month of Debtors "Foreclosure Tuesday" and the Rush to Chapter 13 in the Houston Division of the Southern District of Texas, 24 AM. Bankr. Inst. J. 24, 24 (May 2005).

160. See Gordon Bermant, Making Post-Petition Mortgage Payments Through the Plan: A Survey of Standing Chapter 13 Trustees, A First Draft Report of Survey Results to the Endowment Committee of the National Conference of Bankruptcy Judges (July 2004) (manuscript on file with the author) (reporting on survey of standing Chapter 13 trustees regarding practices respecting payment of mortgages under the plan). See also Gordon Bermant \& Ed Flynn, Bankruptcy by the Numbers, Chapter 13 Disbursements in Fiscal Year 2001: Continued Growth and a New Finding, 22 Am. Bankr. Inst. J. 24, 52 (Feb. 2003) (questioning whether the practice enhances plan completion); Gordon Bermant \& Ed Flynn, Bankruptcy by the Numbers, Chapter 13: Who Pays the Mortgage?, 20 AM. BANKR. INST. J. 20, 20 (June 2001) (reporting that "in 1999 one-third (58/ 175 ) of the standing trustees were making ongoing mortgage payments for at least some of their cases"). 
Carolina and Alabama, which are not part of the United States Trustee system) regarding disbursements by standing Chapter 13 trustees across the country during 1994-2003. Next, we review and compare the national data with EOUST, AO, and Project data on disbursements by the Chapter 13 trustees in the seven districts covered by the Project. This comparison confirms that distributions to creditors in the sample districts are very similar to the national averages. Finally, this Part reports on the repayment of claims by the debtors in the sample cases.

In summary, both the EOUST and AO data on trustee disbursements nationally and the Project data on the sample cases reveal that secured creditors are by far the principal beneficiaries of the Chapter 13 system, and disbursements to priority and general unsecured creditors are modest. Naturally, creditor repayment is significantly related to whether the debtor obtained confirmation of a plan, whether the debtor completed the plan, and the length of time the debtor spent in Chapter 13. Even so, debtors who completed their plans repaid a median amount of just $\$ 630$ per year in general unsecured claims. In all cases, the median disbursement to unsecured creditors was $\$ 0$, and in cases with a confirmed plan, the median was $\$ 14$. Chapter 13 costs deducted from debtors' plan payments compose $15-18 \%$ of total disbursements.

\section{A. Chapter 13 Trustee Disbursements-the National Data \\ 1. Disbursements to Creditors and Chapter 13 Costs}

Table 41 below details disbursements to creditors by the standing Chapter 13 trustees in the United States Trustee Program (USTP) for each of the past ten fiscal years, 1994-2003.161 Total disbursements to

161. The U.S. Trustee Program covers all Chapter 13 trusteeships in the United States except those in North Carolina and Alabama. Over the past six years, Ed Flynn, in the Executive Office for U.S. Trustees, and Gordon Bermant, formerly of the EOUST and now a private consultant, have written a regular column ("Bankruptcy by the Numbers") in the American Bankruptcy Institute Journal on data collected by the EOUST from Chapter 7 and Chapter 13 cases. In regard to Chapter 13, their columns include the following: Gordon Bermant \& Ed Flynn, Bankruptcy by the Numbers, Chapter 13 Disbursements in Fiscal Year 2001: Continued Growth and a New Finding, 22 Aм. Bankr. Inst. J. 24 (Feb. 2003); Gordon Bermant, Ed Flynn, \& Karen Bakewell Bankruptcy by the Numbers, A Tale of Two Chapters, Part I, 21 AM. BANKR. INST. J. 20 (July/ Aug. 2002) (reporting on Chapter 13 filings relative to population in 2001 and total paid out in Chapter 13 cases compared to Chapter 7 cases in 2001); Gordon Bermant \& Ed Flynn, Bankruptcy by the Numbers, Chapter 13 Disbursements in Fiscal Year 2000: Steady Growth, 20 Am. BANKR. Inst. J. 20 (Nov. 2001); Gordon Bermant \& Ed Flynn, Bankruptcy by the Numbers, Chapter 13: Who Pays the Mortgage?, 20 AM. BankR. INST. J. 20 (June 2001); Gordon Bermant \& Ed Flynn, Bankruptcy by the Numbers, Sources of Variability in Chapter 13 Performance, 20 AM. BANKR. INST. J. 20 (Apr. 2001); Gordon Bermant \& Ed Flynn, Bankruptcy by the Numbers, Stability and Change in Chapter 13 Activity, 1990-1999, 19 AM. BANKR. InST. J. 20 (Nov. 2000); Gordon Bermant \& Ed 
creditors have increased substantially and steadily over these ten years, from $\$ 1,654,139,757$ in 1994 to $\$ 3,578,582,446$ in 2003 . Adjusted for inflation, ${ }^{162}$ this is a $74 \%$ increase in disbursements, which primarily reflects the $96.1 \%$ increase in the numbers of Chapter 13 filings over the same period. ${ }^{163}$ Adjusted for inflation, trustee disbursements to secured and unsecured creditors increased by nearly 95\% and 69\%, respectively, between 1994 and 2003; trustee disbursements to priority claimants decreased over the ten years by almost $10 \%$.

Chapter 13 costs (debtor attorney fees, $\S 503$ and noticing expenses, and, most significant, trustee expenses and compensation ${ }^{164}$ ) in the USTP have increased at a somewhat greater rate than disbursements to creditors, from $\$ 285,531,896$ in 1996 to $\$ 594,675,723$ in 2003. Adjusted for inflation, this represents a nearly $78 \%$ increase over the eight-year period, compared to a $68 \%$ increase in total disbursements to creditors (again adjusted for inflation) for the same eight year period. (The eight-year period 1996-2003 is used here for Chapter 13 costs, instead of the 10-year period 1994-2003, because the EOUST Audited Annual Reports for 1994-1995 do not include figures

Flynn, Bankruptcy by the Numbers, Measuring Projected Performance in Chapter 13: Comparisons Across the States, 19 AM. BANKR. INST. J. 22 (July/Aug. 2000) (reporting on Chapter 13 filings, trustee distributions to creditors, and per case distributions to creditors, broken down by high five, middle six, and low five states in FY 1998); Gordon Bermant \& Ed Flynn, Bankruptcy by the Numbers, Distributions and Expenses in Chapter 13, 19 AM. BANKR. INST. J. 22 (May 2000) (reporting on trustee distributions to creditors and trustee expenses in FY 1998); Gordon Bermant \& Ed Flynn, Bankruptcy by the Numbers, A Small New Window on Outcomes in Chapter 13, 19 AM. BANKR. INST. J. 22 (Mar. 2000) (commenting on Norberg study of Chapter 13 cases in the Southern District of Mississippi); Gordon Bermant, Bankruptcy by the Numbers, Exploring the Demographics of Consumer Chapter Choice, 18 AM. BANKR. INST. J. 26 (May 1999) (considering chapter choice by debtors in different jurisdictions based on bankruptcy filings per 1000 households in the jurisdiction).

162. Adjustments for inflation in this section and elsewhere in the article were made using the Consumer Price Index inflation calculator located at http://www.bls.gov.

163. See infra note 170 . As suggested by the fact that the percentage increase in disbursements is less than the percentage increase in filings, average per case disbursements are somewhat lower in 2003 than in 1994. Average per case disbursements are discussed more fully infra, notes 170-74 and accompanying text and Table 42. It should also be noted that the amounts of mortgage debt paid by debtors outside instead of inside their plans have increased over this period, perhaps explaining the balance of the increases in disbursements to creditors over the period. See supra note 160.

164. These are the only costs reported in the EOUST Audited Annual Reports. They are costs deducted from debtor plan payments, therefore, they do not include attorneys' fees paid in advance of the petition. Nor do they include case filing fees, creditor attorney fees, or judicial bankruptcy court and clerk operations, which are hereafter referred to as "other Chapter 13 costs." Figures for debtor attorney fees, § 503(b) awards, and noticing costs are not available for 1994 and 1995. The following table shows the breakdown of Chapter 13 costs for FY 1994-2003. 
for debtor attorney fees, $\S 503(\mathrm{~b})$ awards, and noticing fees, as do the reports for 1996-2003. ${ }^{165}$ )

Secured creditors are by far the primary creditor beneficiaries of the Chapter 13 system. The percentage of total creditor disbursements by trustees to secured creditors ranged between $60 \%$ and $69 \%$ from 1994 and $2003,{ }^{166}$ with an average percentage of nearly $65 \%$. As large as these percentages appear, they substantially understate the proportion of all payments by Chapter 13 debtors to secured creditors. The figures do not include debtors' payments made directly to secured creditors, in particular mortgage creditors; in many districts, some or most debtors pay ongoing mortgage and other secured claims outside the plan. Thus, the percentage of all debtor payments to secured creditors is significantly greater, and the percentage of debtor payments to priority and general unsecured creditors is correspondingly lesser,

\section{CHAPTER 13 COSTS/NATIONAL, FY 1994-2003}

Source: U.S. Trustee Program Chapter 13 Reference Materials, Chapter 13 Statistics, FY-1994-2003 Chapter 13 Standing Trustee Audited Annual Reports, http:/www.usdoj.gov/ust/library/chapter13/ch13lib.htm.

\begin{tabular}{|l|l|c|c|}
\hline FY & $\begin{array}{l}\text { Debtor Attorney Fees, } \\
\text { Co3(b) awards, Noticing } \\
\text { Costs }\end{array}$ & $\begin{array}{c}\text { Trustee Expenses and } \\
\text { Compensation }\end{array}$ & Total Chapter 13 Costs \\
\hline 1994 & Not available & $114,868,685$ & \\
\hline 1995 & Not available & $117,757,752$ & \\
\hline 1996 & $160,266,397$ & $125,265,499$ & $285,531,896$ \\
\hline 1997 & $211,524,484$ & $137,929,713$ & $349,454,197$ \\
\hline 1998 & $248,734,366$ & $153,947,829$ & $402,682,195$ \\
\hline 1999 & $254,506,127$ & $171,789,891$ & $426,296,018$ \\
\hline 2000 & $255,673,005$ & $188,017,901$ & $443,690,906$ \\
\hline 2001 & $276,242,675$ & $203,732,646$ & $479,975,321$ \\
\hline 2002 & $311,008,507$ & $220,778,288$ & $531,786,795$ \\
\hline 2003 & $352,838,946$ & $241,836,777$ & $594,675,723$ \\
\hline
\end{tabular}

165. See supra note 164 and accompanying text.

166. Accord Gordon Bermant \& Ed Flynn, Bankruptcy by the Numbers, Chapter 13 Disbursements in Fiscal Year 2001: Continued Growth and a New Finding, 22 АM. BANKR. INST. J. 24 (Feb. 2003) (observing that percentages of disbursements paid to secured, priority, and general unsecured creditors were relatively constant over time); Gordon Bermant \& Ed Flynn, Bankruptcy by the Numbers, Chapter 13 Disbursements in Fiscal Year 2000: Steady Growth, 20 AM. Bankr. InST. J. 20 (Nov. 2001) (same, regarding 2000); Gordon Bermant \& Ed Flynn, Bankruptcy by the Numbers, Stability and Change in Chapter 13 Activity, 1990-1999, 19 AM. BANKR. INST. J. 20, 20-21 (Nov. 2000) (same, regarding period 1990-1999). See also Gordon Bermant \& Ed Flynn, Bankruptcy by the Numbers, Distributions and Expenses in Chapter 13, 19 Am. BankR. INST. J. 22 (May 2000) (observing large geographical differences in the percentages of distributions to various creditor categories). 
than shown in Table 41, which includes only disbursements made by the Chapter 13 trustees.

No more than $30 \%$ of trustee disbursements are to general unsecured creditors. Between 1994 and 2003, the ratio of general unsecured creditor disbursements to total trustee disbursements ranged from $21 \%$ to $30 \%$. (Again, these figures overstate the proportion of payments to priority and general unsecured creditors; as discussed above, substantial amounts of secured debt were paid directly by debtors.) The ratio of priority unsecured creditor disbursements to total trustee disbursements ranged from $7 \%$ to $14 \%$.

Chapter $13 \operatorname{costs}^{167}$ are a sizable portion of total trustee distributions to creditors and equal a large percentage of disbursements to general unsecured creditors. The ratio of Chapter 13 costs to total trustee disbursements was quite stable over the years 1994 to 2003, ranging from $15 \%$ to $18 \%$. The ratio of Chapter 13 costs to total trustee disbursements to general unsecured creditors ranged between $59 \%$ and $78 \%$, with an average percentage of more than $66 \%$.

167. See supra note 164 and accompanying text regarding costs that are, and are not, included in "Chapter 13 costs." 
TABLE 41. CHAPTER 13 TRUSTEE DISBURSEMENTS/ NATIONAL, FY 1994-2003 ${ }^{168}$

\begin{tabular}{|c|c|c|c|c|c|}
\hline FY & $\begin{array}{l}\text { Disbursements } \\
\text { to Secured } \\
\text { Creditors }\end{array}$ & $\begin{array}{l}\text { Disbursements } \\
\text { to Priority } \\
\text { Creditors }\end{array}$ & $\begin{array}{c}\text { Disbursements } \\
\text { to Unsecured } \\
\text { Creditors }\end{array}$ & \begin{tabular}{|c|} 
Total Trustee \\
Disbursements \\
to Creditors
\end{tabular} & $\begin{array}{c}\text { Chapter } 13 \\
\text { Costs }\end{array}$ \\
\hline 1994 & $1,019,284,401$ & $223,656,042$ & $411,199,314$ & $1,654,139,757$ & $\mathrm{n} / \mathrm{a}$ \\
\hline $\begin{array}{l}\text { \% Total Trustee } \\
\text { Disbursements }\end{array}$ & $62 \%$ & $14 \%$ & $25 \%$ & & $\mathbf{n} / \mathbf{a}$ \\
\hline $\begin{array}{l}\text { \% Disbursements } \\
\text { to Uns.Creds. }\end{array}$ & & & & & $\mathrm{n} / \mathbf{a}$ \\
\hline 1995 & $1,046,389,221$ & $195,323,850$ & $428,119,256$ & $1,669,832,327$ & $\mathrm{n} / \mathrm{a}$ \\
\hline $\begin{array}{l}\text { \% Total Trustee } \\
\text { Disbursements }\end{array}$ & $63 \%$ & $12 \%$ & $26 \%$ & & $\mathrm{n} / \mathrm{a}$ \\
\hline $\begin{array}{l}\text { \% Disbursements } \\
\text { to Uns.Creds. }\end{array}$ & & & & & $\mathrm{n} / \mathrm{a}$ \\
\hline 1996 & $1,156,100,247$ & $219,725,022$ & $439,756,339$ & $1,815,581,608$ & $285,531,896$ \\
\hline $\begin{array}{l}\text { \% Total Trustee } \\
\text { Disbursements }\end{array}$ & $64 \%$ & $12 \%$ & $24 \%$ & & $16 \%$ \\
\hline $\begin{array}{l}\text { \% Disbursements } \\
\text { to Uns.Creds. }\end{array}$ & & & & & $65 \%$ \\
\hline 1997 & $1,382,780,488$ & $244,042,513$ & $4 \overline{65,842,310}$ & $2,092,665,311$ & $349,454,197$ \\
\hline $\begin{array}{l}\text { \% Total Trustee } \\
\text { Disbursements }\end{array}$ & $66 \%$ & $12 \%$ & $22 \%$ & & $17 \%$ \\
\hline $\begin{array}{l}\text { \% Disbursements } \\
\text { to Uns.Creds. }\end{array}$ & & & & & $75 \%$ \\
\hline 1998 & $1,700,257,785$ & $275,462,767$ & $536,423,390$ & $2,512,143,942$ & $402,682, \overline{195}$ \\
\hline $\begin{array}{l}\text { \% Total Trustee } \\
\text { Disbursements }\end{array}$ & $68 \%$ & $11 \%$ & $21 \%$ & & $16 \%$ \\
\hline $\begin{array}{l}\text { \% Disbursements } \\
\text { to Uns.Creds. }\end{array}$ & & & & & $75 \%$ \\
\hline 1999 & $1,631,712,848$ & $297,617,217$ & $647,918,439$ & $2,577,248,501$ & $426,296,018$ \\
\hline $\begin{array}{l}\text { \% Total Trustee } \\
\text { Disbursements }\end{array}$ & $63 \%$ & $12 \%$ & $25 \%$ & & $17 \%$ \\
\hline $\begin{array}{l}\text { \% Disbursements } \\
\text { to Uns.Creds. }\end{array}$ & & & & & $66 \%$ \\
\hline 2000 & $1,955,834,912$ & $290,092,433$ & $753,959,479$ & $2,999,886,824$ & $443,690,906$ \\
\hline $\begin{array}{l}\text { \% Total Trustee } \\
\text { Disbursements }\end{array}$ & $65 \%$ & $10 \%$ & $25 \%$ & & $15 \%$ \\
\hline $\begin{array}{l}\text { \% Disbursements } \\
\text { to Uns.Creds. }\end{array}$ & & & & & $59 \%$ \\
\hline 2001 & $1,651,694,504$ & $272,376,337$ & $815,847,426$ & $2,739,918,267$ & $479,975,321$ \\
\hline $\begin{array}{l}\text { \% Total Trustee } \\
\text { Disbursements }\end{array}$ & $60 \%$ & $10 \%$ & $30 \%$ & & $18 \%$ \\
\hline $\begin{array}{l}\text { \% Disbursements } \\
\text { to Uns.Creds. }\end{array}$ & & & & & $59 \%$ \\
\hline 2002 & $2,212,112,114$ & $256,280,549$ & $841,370,358$ & $3,309,763,021$ & $531,786,795$ \\
\hline $\begin{array}{l}\text { \% Total Trustee } \\
\text { Disbursements }\end{array}$ & $67 \%$ & $8 \%$ & $25 \%$ & & $16 \%$ \\
\hline $\begin{array}{l}\text { \% Disbursements } \\
\text { to Uns.Creds. }\end{array}$ & & & & & $63 \%$ \\
\hline 2003 & $2,4 \overline{465,442,929}$ & $251,213,403$ & $861,926,114$ & $3,578,582,446$ & $594,675,723$ \\
\hline $\begin{array}{l}\text { \% Total Trustee } \\
\text { Disbursements }\end{array}$ & $69 \%$ & $7 \%$ & $24 \%$ & & $17 \%$ \\
\hline $\begin{array}{l}\text { \% Disbursements } \\
\text { to Uns.Creds. }\end{array}$ & & & & & $69 \%$ \\
\hline $\begin{array}{l}\text { \% increase } \\
\text { (adjusted for } \\
\text { inflation), 1994- } \\
2003\end{array}$ & $95 \%$ & $-10 \%$ & $69 \%$ & $74 \%$ & $78 \% 169$ \\
\hline
\end{tabular}

168. U.S. Trustee Program Chapter 13 Reference Materials, Chapter 13 Statistics, FY 1994-2003 Chapter 13 Standing Trustee Audited Annual Reports, at http://www. usdoj.gov/ust/library/chapter13/ch13lib.htm.

169. This is the percent increase for 1996-2003. Figures for "Chapter 13 costs" in 1994 and 1995 are not available, see supra note 164 . 


\section{Disbursements per Case}

No one maintains statistics on average per case disbursements in Chapter 13 cases, but a reasonably accurate estimate can be computed by dividing the disbursements in a given year by the average of all Chapter 13 filings for that and the previous four years. ${ }^{170}$ As shown in Table 42 below, in absolute dollars, average Chapter 13 trustee disbursements to creditors per case in the USTP have increased, albeit somewhat erratically, over the ten years 1994-2003. ${ }^{171}$ When adjusted for inflation, however, average total trustee per case distributions to all creditors declined slightly, by $1.4 \%$, between 1994 and 2003. Per case payments to priority and unsecured creditors fell by $48.8 \%$ and $0.4 \%$, respectively. On the other hand, trustee distributions to secured creditors were $10.2 \%$ higher in 2003 than in $1994 .{ }^{172}$

170. See Gordon Bermant \& Ed Flynn, Estimating the Yield to Creditors of Chapter 13 Cases, available at http://www.usdoj.gov/ust/eo/public_affairs/articles/docs/abi1020 00a.htm (discussing methodology for computing per case yields in Chapter 13 cases and deriving formula: mean yield per case $=$ yield FY00/mean filings CY00-CY04).

Chapter 13 filings in all districts for the years 1990-2003 are as follows:

\begin{tabular}{|c|c|c|}
\hline \multicolumn{3}{|c|}{ Chapter 13 Filings, 1994-2003 } \\
\hline Year & Chapter 13 Filings - All Districts & Chapter 13 Filings - USTP Districts \\
\hline 1990 & 208,666 & $-14,045[\mathrm{AL}],-7,160[\mathrm{NC}] 187,461$ \\
\hline 1991 & 251,883 & $-15,995[\mathrm{AL}],-9,771[\mathrm{NC}] 226,117$ \\
\hline 1992 & 254,138 & $-15,411[\mathrm{AL}],-8,320[\mathrm{NC}] \quad 230,407$ \\
\hline 1993 & 241,464 & $-14,816[\mathrm{AL}],-7,535[\mathrm{NC}] \quad 219,113$ \\
\hline 1994 & 240,639 & 217,603 \\
\hline 1995 & 276,225 & 248,720 \\
\hline 1996 & 343,987 & 310,108 \\
\hline 1997 & 391,832 & 355,903 \\
\hline 1998 & 389,363 & 354,497 \\
\hline 1999 & 377,640 & 344,660 \\
\hline 2000 & 378,366 & 343,238 \\
\hline 2001 & 419,660 & 380,568 \\
\hline 2002 & 454,293 & 413,910 \\
\hline 2003 & 467,908 & 426,738 \\
\hline
\end{tabular}

171. Gordon Bermant and Ed Flynn have reported calculations on average disbursements per case for some of these years. Their calculations are almost identical to those reported in Table 41. See Gordon Bermant \& Ed Flynn, Bankruptcy by the Numbers, Chapter 13 Disbursements in Fiscal Year 2000: Steady Growth, 20 AM. BANkR. INST. J. 20,20 , Table 5 (Nov. 2001) (reporting on total disbursements per case, disbursements to creditors, and disbursements to unsecured creditors in 1998, 1999, and 2000); Gordon Bermant \& Ed Flynn, Bankruptcy by the Numbers, Estimating Means-tested Chapter 13 Case Yields from Current Chapter 13 Performance (June 2000) available at http://www. usdoj.gov/ust/eo/public_affairs/articles/docs/abi00junnumbers.html (reporting average disbursements per case to unsecured creditors in 1998).

172. Adjusted for inflation, using the Consumer Price Index, average disbursements to creditors in 1994, expressed in 2003 dollars, were $\$ 5855$ to secured creditors, $\$ 1285$ to 
As reported in Table 42, the average amount disbursed by standing Chapter 13 trustees in the USTP to secured creditors in 2003 was $\$ 6457$ per case, nearly three times the average amount disbursed to unsecured creditors, which was $\$ 2257$ per case.

\section{TABLE 42. AVERAGE CHAPTER 13 DISBURSEMENTS PER} CASE (USTP), 1994-2003173

\begin{tabular}{|c|c|c|c|c|c|c|}
\hline FY & $\begin{array}{c}\text { Disbursements } \\
\text { to Secured } \\
\text { Creditors }\end{array}$ & $\begin{array}{c}\text { Disbursements } \\
\text { to Priority } \\
\text { Creditorg }\end{array}$ & $\begin{array}{c}\text { Disbursements } \\
\text { to Unsecured } \\
\text { Creditors }\end{array}$ & $\begin{array}{c}\text { Total Trustee } \\
\text { Disbursements } \\
\text { to Creditors }\end{array}$ & Costs 174 & $\begin{array}{c}\text { Mean } \\
\text { Filings, } \\
\text { CY0- } \\
\text { CY4 } \\
\end{array}$ \\
\hline 1994 & $1,019,284,401$ & $22 \overline{3}, 656, \overline{0} \overline{2}$ & $411,199,314$ & $1,654,139,757$ & $\mathrm{n} / \mathrm{a}$ & 216,140 \\
\hline Avg. per case & $47 \overline{16}$ & 1035 & 1902 & 7653 & & \\
\hline 1995 & $1,046,389,221$ & $195,323,850$ & $428,119,256$ & $1,669,832,327$ & $\mathrm{n} / \mathrm{a}$ & 228,392 \\
\hline Avg per case & 4582 & 855 & 1874 & 7311 & & \\
\hline 1996 & $1,156,100,247$ & $219,725,022$ & $439,756,339$ & $1,815,581,608$ & $285,531,896$ & 245,190 \\
\hline Avg. per case & 4715 & 896 & 1794 & 7405 & 1165 & \\
\hline 1997 & $1,382,780,488$ & $24 \overline{4}, 042,51 \overline{3}$ & $465,842,310$ & $2,092,665,311$ & $\mathbf{3 4 9 , 4 5 4 , 1 9 7}$ & 270,289 \\
\hline Avg. per case & 5116 & 903 & 1723 & 7742 & 1293 & \\
\hline 1998 & $1,700,257,785$ & $275,462,767$ & $536,423,390$ & $2,512,143,942$ & $402,682,195$ & 297,366 \\
\hline Avg. per case & 5718 & 926 & 1803 & 8448 & 1354 & \\
\hline 1999 & $1,631,712,848$ & $297,617,217$ & $647,918,439$ & $2,577,248,501$ & $426,296,018$ & 322,778 \\
\hline Avg. per case & 5055 & 922 & 2007 & 7985 & 1320 & \\
\hline 2000 & $1,955,834,912$ & $290,092,433$ & $753,959,479$ & $2,999,886,824$ & $443,690,906$ & 341,681 \\
\hline Avg. per case & $572 \overline{4}$ & 849 & 2207 & 8780 & 1299 & \\
\hline 2001 & $1,651,694,504$ & $272,376,337$ & $815,847,426$ & $2,739,918,267$ & $479,975,321$ & 355,773 \\
\hline Avg. per case & 4643 & 766 & 2293 & 7701 & 1349 & \\
\hline 2002 & $2,212,112,114$ & $256,280,549$ & $841,370,358$ & $3,309,763,021$ & $531,786,795$ & 367,375 \\
\hline Avg. per case & 6021 & 698 & 2290 & 9009 & 1448 & \\
\hline 2003 & $2,465,442,929$ & $251,213,403$ & $861,926,114$ & $3,578,582,446$ & $594,675,723$ & 381,823 \\
\hline Avg. per case & 6457 & 658 & 2257 & 9372 & 1557 & \\
\hline
\end{tabular}

Several factors likely have contributed to the increase in the average trustee distributions to secured creditors, and to the decreases in the average trustee distributions to general unsecured creditors. Perhaps most important, it appears that over the past twelve years, more Chapter 13 trustees are administering mortgage payments, and fewer debtors are making these payments directly to the mortgagee. In addition, the Supreme Court's decision in Associates Commercial Corp. v. Rash $^{\mathbf{1 7 5}}$ may have had the effect of shifting some of debtors' dispos-

priority creditors, $\$ 2361$ to general unsecured creditors, and $\$ 9501$ to all creditors combined. By comparison, average disbursements to creditors in 2003 (expressed in 2003 dollars) were $\$ 6457$ to secured creditors, $\$ 658$ to priority creditors, $\$ 2257$ to general unsecured creditors, and $\$ 9372$ to all creditors combined. Adjusted for inflation, again using the Consumer Price Index, average Chapter 13 costs in 1996, expressed in 2003 dollars, were $\$ 1366$. By comparison, average per case costs in 2003 were $\$ 1557$. Adjustments for inflation were made using the Inflation Calculator located at http://www.bls. gov/.

173. Creditor disbursement figures are derived from U.S. Trustee Program Chapter 13 Reference Materials, Chapter 13 Statistics, FY 1994-2003 Chapter 13 Standing Trustee Audited Annual Reports, http://www.usdoj.gov/ust/library/chapter13/ch13lib. htm (last visited Dec. 14, 2004). For Chapter 13 filing statistics, see supra note 1. Filings in North Carolina and Alabama are excluded because the EOUST Audited Annual Reports cover only the USTP trusteeships.

174. See supra note 164 regarding costs that are, and are not, included in "Chapter 13 costs."

175. 520 U.S. 953 (1997). 
able income from payment of unsecured claims to payment of secured claims. The Court in Rash held that the proper valuation standard for collateral that the debtor proposes to retain in Chapter 13 is replacement value, not liquidation value. As a result of the decision, in courts that had previously valued collateral at something less than "replacement value," the amount of secured claims, which must be paid in full, has increased. ${ }^{176}$ The 1998 amendments permitting Chapter 13 debtors to make charitable and religious contributions also may have somewhat decreased distributions to unsecured creditors. ${ }^{177}$

\section{B. Chapter 13 Trustee Disbursements in the Seven Sample Districts/EOUST and AO Data}

Tables 43 and 44 indicate that the seven sample districts closely resemble the nation with respect to (a) the ratio of trustee disbursements to secured, priority, and unsecured creditors to total trustee disbursements, (b) the increases in disbursements over the period 1994-2003, and (c) the ratio of Chapter 13 costs to total creditor and to unsecured creditor disbursements. As with disbursements to creditors in all districts, ${ }^{178}$ disbursements to creditors in the seven sample districts primarily benefited secured creditors. In 1994, just over $60 \%$ of Chapter 13 trustee disbursements went to secured creditors in the seven sample districts, compared to $62 \%$ in all USTP districts. In 2003, 74.4\% of trustee disbursements went to secured creditors in the sample districts, compared to $69 \%$ in all USTP districts. As is the case for all USTP districts, ${ }^{179}$ these data for the seven sample districts substantially understate payments to secured creditors because they do not include debtor payments outside the plan. In 1994, debtors in three of the seven districts in the Project - the Northern District of Georgia, Southern District of Georgia, and District of Maryland - typically paid ongoing mortgage payments (but not mortgage arrearages) outside the plan, and currently debtors in Maryland generally do not make ongoing mortgage payments through their plans. ${ }^{180}$

176. See Scott F. Norberg, Consumer Bankruptcy's New Clothes: An Empirical Study of Discharge and Debt Collection in Chapter 13, 7 Am. BANkR. INST. L. REv. 415, 439-40 (1999) (commenting on future trends in repaying of unsecured debt in Chapter 13 cases).

177. 11 U.S.C. $\$ 1325(\mathrm{~b})(2)(\mathrm{A})(\mathrm{ii})$ provides that "disposable income" that must be committed to a plan does not include "amounts reasonably necessary to be expended ... for charitable contributions ... in an amount not to exceed 15 percent of gross income of the debtor . . . ."

178. See supra note 166 and accompanying text and Table 41.

179. See id.

180. It also appears that in 1994 in the Western District of Tennessee, disbursements to some secured creditors were reported as disbursements to priority claimants. 
Total trustee disbursements to creditors in the seven sample districts increased from $\$ 319,984,097$ in 1994 to $\$ 727,390,828$ in 2003 . Adjusted for inflation, this is an $83 \%$ increase, compared to $74 \%$ nationally. Disbursements to unsecured creditors rose from $\$ 66,798,014$ to $\$ 133,855,268$. Adjusted for inflation, this is a $76 \%$ increase, compared to $69 \%$ nationally.

In FY2003, in six of the seven sample districts, ${ }^{181}$ Chapter 13 costs in the USTP were $\$ 83,483,018$, equal to $13.8 \%$ of total payments to creditors and $71.8 \%$ of payments to general unsecured creditors. As discussed above, nationally, in 2003, total Chapter 13 costs composed $16.6 \%$ of all disbursements and equaled $70 \%$ of payments to general unsecured creditors.

TABLE 43. CHAPTER 13 TRUSTEE DISBURSEMENTS/SAMPLE DISTRICTS, FY $1994^{182}$

\begin{tabular}{|l|c|c|c|c|}
\hline \multicolumn{1}{|c|}{ District } & Secured & Priority & Unsecured & $\begin{array}{c}\text { Total Trustee } \\
\text { Disbursements } \\
\text { to Creditors }\end{array}$ \\
\hline WDPA [1 trustee] & $\$ 10,403,822$ & $\$ 1,440,902$ & $\$ 1,938,179$ & $\$ 13,782,903$ \\
\hline$\%$ & $\mathbf{7 5 . 5}$ & $\mathbf{1 0 . 4}$ & $\mathbf{1 4 . 1}$ & $\mathbf{1 0 0 . 0}$ \\
\hline DMD [2 trustees] & $\$ 10,489,863$ & $\$ 3,365,856$ & $\$ 7,973,861$ & $\$ 21,829,580$ \\
\hline$\%$ & $\mathbf{4 8 . 1}$ & $\mathbf{1 5 . 4}$ & $\mathbf{3 6 . 5}$ & $\mathbf{1 0 0 . 0}$ \\
\hline WDTN [3 trustees] & $\$ 35,548,973$ & $\$ 44,387,550$ & $\$ 12,636,438$ & $\$ 92,572,961$ \\
\hline$\%$ & $\mathbf{3 8 . 4}$ & $\mathbf{4 7 . 9}$ & $\mathbf{1 3 . 7}$ & $\mathbf{1 0 0 . 0 0}$ \\
\hline MDTN [2 trustees] & $\$ 48,270,109$ & $\$ 4,497,699$ & $\$ 16,839,363$ & $\$ 69,607,171$ \\
\hline$\%$ & $\mathbf{6 9 . 3}$ & $\mathbf{6 . 5}$ & $\mathbf{2 4 . 2}$ & $\mathbf{1 0 0 . 0}$ \\
\hline SDGA [2 trustees] & $\$ 22,199,605$ & $\$ 1,428,262$ & $\$ 7,978,796$ & $\$ 31,606,663$ \\
\hline$\%$ & $\mathbf{7 0 . 2}$ & $\mathbf{4 . 5}$ & $\mathbf{2 5 . 2}$ & $\mathbf{1 0 0 . 0}$ \\
\hline NDGA [2 trustees] & $\$ 66,064,393$ & $\$ 5,089,049$ & $\$ 19,431,377$ & $\$ 90,524,819$ \\
\hline$\%$ & $\mathbf{7 3 . 0}$ & $\mathbf{5 . 6}$ & $\mathbf{2 1 . 5}$ & $\mathbf{1 0 0 . 0}$ \\
\hline MDNC [3 trustees] & $\$ 38,003,785$ & $\$ 2,243,266$ & $\$ 10,119,396$ & $\$ 50,366,447$ \\
\hline$\%$ & $\mathbf{7 5 . 5}$ & $\mathbf{4 . 5}$ & $\mathbf{2 0 . 1}$ & $\mathbf{1 0 0 . 0}$ \\
\hline Total [7 districts/15 trustees] & $\$ 192,976,765$ & $\$ 60,209,318$ & $\$ 66,798,014$ & $\$ 319,984,097$ \\
\hline$\%$ & $\mathbf{6 0 . 3}$ & $\mathbf{1 8 . 8}$ & $\mathbf{2 0 . 9}$ & $\mathbf{1 0 0 . 0}$ \\
\hline
\end{tabular}

181. The Middle District of North Carolina is excluded from the calculations here because Chapter 13 costs were not available for two of the three trustees in that district.

182. U.S. Trustee Program Chapter 13 Reference Materials, Chapter 13 Statistics, FY1994 Chapter 13 Standing Trustee Audited Annual Report, at http://www.usdoj.gov/ ust/library/chapter13/ch13lib.htm (last visited Dec. 14, 2004). The Audited Annual Report for FY 1994 itemizes trustee expenses and compensation, but not debtor attorney fees, $\S 503$ (b) awards, and noticing costs. Thus, "Chapter 13 costs" are not included in this Table because they are not comparable to these costs as reported in the other tables in this Part. 
TABLE 44. CHAPTER 13 TRUSTEE DISBURSEMENTS/SAMPLE DISTRIC'TS, FY $2003^{183}$

\begin{tabular}{|c|c|c|c|c|c|}
\hline District & \begin{tabular}{|c|} 
Disbursements \\
to Secured \\
Creditors
\end{tabular} & $\begin{array}{c}\text { Disbursements } \\
\text { to Priority } \\
\text { Creditors }\end{array}$ & $\begin{array}{c}\text { Disbursements } \\
\text { to Unsecured } \\
\text { Creditors }\end{array}$ & \begin{tabular}{|c|} 
Total Trustee \\
Disbursements \\
to Creditors
\end{tabular} & $\begin{array}{c}\text { Chapter } 13 \\
\text { Costs } 184\end{array}$ \\
\hline WDPA [1 trustee] & $\$ 33,531,809$ & $\$ 2,524,020$ & $\$ 3,319,329$ & $\$ 39,375,158$ & $3,405,299$ \\
\hline $\begin{array}{l}\text { \% Total Trustee } \\
\text { Disbursements }\end{array}$ & 85.2 & 6.4 & 8.4 & 100.0 & 8.6 \\
\hline $\begin{array}{l}\text { \% Disbursements to } \\
\text { Uns.Creds. }\end{array}$ & & & & & 102.5 \\
\hline DMD [4 trustees] & $\$ 35,757,547$ & $\$ 8,395,187$ & $\$ 27,061,911$ & $\$ 71,214,645$ & $9,791,328$ \\
\hline $\begin{array}{l}\text { \% Total Trustee } \\
\text { Disbursements }\end{array}$ & 50.2 & 11.8 & 38.0 & 100.0 & 13.7 \\
\hline $\begin{array}{l}\text { \% Disbursements to } \\
\text { Uns.Creds. }\end{array}$ & & & & & 36.2 \\
\hline WDTN [3 trustees] & $\$ 149,504,123$ & $\$ 8,435,127$ & $\$ 25,305,756$ & $\$ 183,245,012$ & $18,676,913$ \\
\hline $\begin{array}{l}\text { \% Total Trustee } \\
\text { Disbursements }\end{array}$ & 81.6 & 4.6 & 13.8 & 100.0 & 10.2 \\
\hline $\begin{array}{l}\text { \% Disbursements to } \\
\text { Uns.Creds. }\end{array}$ & & & & & 73.8 \\
\hline MDTN [1 trustee] & $\$ 77,258,620$ & $\$ 5,594,587$ & $\$ 17,798,404$ & $\$ 100,651,611$ & $8,264,390$ \\
\hline $\begin{array}{l}\text { \% Total Trustee } \\
\text { Disbursements }\end{array}$ & 76.8 & 5.5 & 17.7 & 100.0 & 8.2 \\
\hline $\begin{array}{l}\text { \% Disbursements to } \\
\text { Uns.Creds. }\end{array}$ & & & & & 46.4 \\
\hline SDGA [2 trustees] & $\$ 53,357,982$ & $\$ 2,919,875$ & $\$ 15,283,964$ & $\$ 71,561,821$ & $14,292,572$ \\
\hline $\begin{array}{l}\text { \% Total Trustee } \\
\text { Disbursements }\end{array}$ & 74.6 & 4.1 & 21.4 & 100.0 & 20.0 \\
\hline $\begin{array}{l}\text { \% Disbursements to } \\
\text { Uns.Creds. }\end{array}$ & & & & & 93.5 \\
\hline NDGA [2 trustees] & $\$ 99,603,676$ & $\$ 10,009,867$ & $\$ 27,569,736$ & $\$ 137,183,279$ & $29,052,516$ \\
\hline $\begin{array}{l}\text { \% Total Trustee } \\
\text { Disbursements }\end{array}$ & 72.6 & 7.3 & 20.1 & 100.0 & 21.2 \\
\hline $\begin{array}{l}\text { \% Disbursements to } \\
\text { Uns.Creds. }\end{array}$ & & & & & 105.4 \\
\hline $\begin{array}{l}\text { Total [6 Districts/13 } \\
\text { trustees - excl. } \\
\text { MDNC*] }\end{array}$ & & & $116,339,100$ & $603,231,526$ & $83,483,018$ \\
\hline $\begin{array}{l}\text { \% Total Trustee } \\
\text { Disbursements }\end{array}$ & & & & & 13.8 \\
\hline $\begin{array}{l}\text { \% Disbursements to } \\
\text { Uns.Creds. }\end{array}$ & & & & & 71.8 \\
\hline MDNC [3 trustees] & $\$ 103,825,645$ & $\$ 2,817,500$ & $\$ 17,516,156$ & $\$ 124,159,302$ & $n / a$ \\
\hline $\begin{array}{l}\text { \% Total Trustee } \\
\text { Disbursements }\end{array}$ & 83.6 & 2.3 & 14.1 & 100.0 & $\mathbf{n} / \mathbf{a}$ \\
\hline $\begin{array}{l}\text { \% Disbursements to } \\
\text { Uns.Creds. }\end{array}$ & & & & & $\mathrm{n} / \mathrm{a}$ \\
\hline $\begin{array}{l}\text { Total [7 Districts/16 } \\
\text { trustees] }\end{array}$ & $\$ 552,893,402$ & $\$ 40,696,169$ & $\$ 133,855,268$ & $\$ 727,390,828$ & \\
\hline $\begin{array}{l}\text { \% Total Trustee } \\
\text { Disbursements }\end{array}$ & 76.0 & 5.6 & 18.4 & 100.0 & \\
\hline $\begin{array}{l}\text { National/All Districts/ } \\
\text { Trustees }\end{array}$ & $\$ 2,465,442,929$ & $\$ 251,213,403$ & $\$ 861,926,114$ & $\$ 3,576,273,283$ & $594,675,723$ \\
\hline $\begin{array}{l}\text { \% Total Trustee } \\
\text { Disbursements }\end{array}$ & 68.9 & 7.0 & 24.1 & 100.0 & 16.6 \\
\hline $\begin{array}{l}\text { \% Disbursements to } \\
\text { Uns.Creds. }\end{array}$ & & & & & 70.0 \\
\hline
\end{tabular}

183. U.S. Trustee Program Chapter 13 Reference Materials, Chapter 13 Statistics, FY-2003 Chapter 13 Standing Trustee Audited Annual Report, http://www.usdoj.gov/ ust/library/chapter13/ch13lib.htm (last visited Dec. 14, 2004).

184. MDNC is excluded from the calculations in this column because Chapter 13 costs are not available for two of the three trustees in that district. 


\section{Trustee Disbursements in the Seven Sample Districts/ Project Data}

\section{Allowed Claims}

Table 45 below sets out the amounts of allowed secured, priority, general, other, and total claims in the sample cases. Secured claims made up nearly $49 \%$ of all allowed claims (but, again, the Table understates these claims because the data do not include some claims to be paid outside a plan; in districts where claims may be paid outside the plan, such claims usually are (relatively quite) large mortgage claims). Nearly $42 \%$ of the total allowed claims were general unsecured claims. According to the Chapter 13 trustee data, priority and other claims composed $7.8 \%$ and $4.5 \%$, respectively, of total allowed claims. (In some trusteeships, however, the "priority" and "other" claims categories include at least some post-petition, administrative expense claims, most importantly attorneys' fees. As a result, meaningful analysis of the extent of payment of pre-petition priority and other claims was not possible. ${ }^{185}$ )

TABLE 45. ALLOWED CLAIMS IN ALL SAMPLE CASES

\begin{tabular}{|l|c|c|}
\hline Claims & Total & \% of Total \\
\hline Secured & $\$ 9,123,669$ & $48.6 \%$ \\
\hline Priority & $\$ 1,453,874$ & $7.8 \%$ \\
\hline General & $\$ 7,787,414$ & $41.5 \%$ \\
\hline Other & $\$ 844,746$ & $4.5 \%$ \\
\hline Total & $\$ 18,754,741$ & $100 \%$ \\
\hline
\end{tabular}

2. Disbursements Per Case and Overall in Chapter 13 Project Cases a. All Sample Cases

As reported in Table 46 below, debtors in the sample Chapter 13 cases paid an average of $\$ 9,406$ per case under their Chapter 13 plans. ${ }^{186}$ The median was much lower, $\$ 2,718$, and the standard deviation was large, $\$ 16,207$, indicating that a relatively few debtors repaid substantially greater amounts of debt. The positively skewed distribution around the mean is further reflected in the minimal 10th and 25th percentile amounts of $\$ 0$ and $\$ 22$, respectively; and the rela-

185. See also Gordon Bermant \& Ed Flynn, Bankruptcy by the Numbers, Sources of Variability in Chapter 13 Performance, 20 AM. BANKR. INST. J. 20 (Apr. 2001) (stating that "there are good reasons to believe ... that this category [priority claims] is treated differently in different districts, so the exact extent of priority debt and repayment is not completely clear at the national level").

186. This compares to $\$ 24,294$ in average allowed claims per case. See supra notes 39-41 and accompanying text and Table 8. 
tively large 75 th and 90 th percentile amounts of $\$ 11,326$ and $\$ 28,490$. The standard error of the mean is relatively low, so the confidence level is high; the mean is accurate to within plus or minus $\$ 581$, or approximately $6 \%$, of the mean. ${ }^{187}$

Secured Claims. Not counting any debtor payments directly to secured creditors (outside the plan), secured creditors collected an average of $\$ 6,593$ per case. Again, the lower median amount of $\$ 1,141$ collected by secured creditors and the high standard deviation, $\$ 12,835$, nearly two times the mean, indicate that a relatively fewer number of debtors paid higher amounts of secured debt. Thus, at the 75 th percentile, creditors collected $\$ 6,877$, barely more than the mean of $\$ 6,593$; and at the 90 th percentile, creditors collected $\$ 20,241$, approximately three times the mean.

Priority Claims. In a large majority of cases (515 of 784, or $66 \%$ ), the debtors paid no priority debt, thus there is a non-normal distribution in these Table 46 figures. While debtors paid an average of $\$ 1,110$ per case, the median was $\$ 0$ and the 75 th percentile was only $\$ 117$. As the standard deviation ( $\$ 4560$, or four times the mean) and 90th percentile $(\$ 2,389)$ figures indicate, a very few debtors paid the vast bulk of the priority debt that was repaid by the debtors in the sample. As noted above, however, this data must be viewed with caution because different districts report the extent and repayment of priority debt somewhat differently.

General Unsecured Claims. The debtors repaid an average of $\$ 1,683$ of unsecured debt per case. The data reveal that a relatively fewer number of debtors repaid a relatively larger amount of unsecured debt. The median amount of unsecured debt repaid by debtors was $\$ 0$ - in other words, half of all of the Chapter 13 debtors in the sample paid nothing to unsecured creditors. The standard deviation was $\$ 4,261$, or nearly two and one-half times the mean. The 75 th percentile amount, $\$ 1,401$, was similar to the mean of $\$ 1,683$.

187. Again, the figures in Table 46 somewhat understate the debt repaid by Chapter 13 debtors because the trustee and court file data do not track payments made outside the plan directly to creditors. In some districts, debtors sometimes or routinely paid certain claims - usually mortgage claims and occasionally other secured claims outside the plan. 
TABLE 46. CREDITOR COLLECTION PER CASE: ALL CASES 188

\begin{tabular}{|c|c|c|c|c|c|c|c|c|c|c|c|}
\hline & $N$ & $\begin{array}{c}\# \text { cases } \\
\text { with } \\
\text { value } \\
\$ 0\end{array}$ & Range & Mean & $S D$ & $S E M$ & $10 \%$ & $25 \%$ & Median & $75 \%$ & $90 \%$ \\
\hline Secured & $\begin{array}{c}785 \\
(10 \text { missing })\end{array}$ & $\begin{array}{c}270 \\
(34 \%)\end{array}$ & $\begin{array}{l}\$ 0- \\
\$ 108,096\end{array}$ & $\$ 6,593$ & $\$ 12,835$ & 458 & $\$ 0$ & $\$ 0$ & $\$ 1,141$ & $\$ 6,877$ & $\$ 20,241$ \\
\hline PrortTY & $\begin{array}{c}784 \\
(11 \text { missing })\end{array}$ & $\begin{array}{c}515 \\
(65 \%)\end{array}$ & $\begin{array}{l}\$ 0- \\
\$ 54,598^{*}\end{array}$ & $\$ 1,110$ & $\$ 4,560$ & 162.84 & $\$ 0$ & $\$ 0$ & $\$ 0$ & $\$ 117$ & $\$ 2,389$ \\
\hline GENERAL & $\begin{array}{c}784 \\
(11 \text { missing })\end{array}$ & $\begin{array}{c}473 \\
(59 \%)\end{array}$ & $\$ 0-\$ 57,714$ & $\$ 1,683$ & $\$ 4,261$ & 152 & $\$ 0$ & $\$ 0$ & $\$ 0$ & $\$ 1,401$ & $\$ 5,662$ \\
\hline Total & $\begin{array}{c}776 \\
(19 \text { missing })\end{array}$ & $\begin{array}{c}188 \\
(24 \%)\end{array}$ & $\$ \$ 131,886$ & $\$ 9,406$ & $\$ 16,207$ & 581.8 & $\$ 0$ & $\$ 22$ & $\$ 2,718$ & $\$ 11,326$ & $\$ 28,490$ \\
\hline
\end{tabular}

As shown in Table 47 below, overall, more than $70 \%$ of the payments by Chapter 13 debtors under their plans went to secured creditors. ${ }^{189}$ Payments to priority creditors were nearly $12 \%$ and payments to general unsecured creditors composed $19.5 \%$ of total payments to creditors inside the plan.

Table 47 also shows the percent of each type of claim paid by the debtors in the study sample. They paid a modest $30 \%$ of allowed secured claims and a somewhat lesser $19.5 \%$ of unsecured claims. We have omitted repayment of priority claims from the Table because of the variability among districts in what is included in this category and the fact that some of the districts included post-petition administrative expense claims, in particular attorneys' fees, in this category.

TABLE 47. OVERALL CREDITOR COLLECTIONS: ALL CASES

\begin{tabular}{|l|c|c|c|c|}
\hline & Secured & Priority & General & All Claims \\
\hline $\begin{array}{l}\text { Total Allowed } \\
\text { Amount }\end{array}$ & $\$ 16,928,389$ & $\$ 1,014,124$ & $\$ 6,780,540$ & $\$ 24,262,802$ \\
\hline Total Payments & $\$ 5,175,346$ & $\$ 870,931$ & $\$ 1,320,110$ & $\$ 7,299,525$ \\
\hline $\begin{array}{l}\% \text { of Allowed } \\
\text { Claims Paid }\end{array}$ & $30.6 \%$ & & $19.5 \%$ & $30.1 \%$ \\
\hline $\begin{array}{l}\% \text { of Total } \\
\text { Payments }\end{array}$ & $70.9 \%$ & $11.9 \%$ & $18.1 \%$ & 100.0 \\
\hline
\end{tabular}

\section{b. Cases with a Confirmed Plan}

Perhaps the better measure of creditor repayment in Chapter 13 is debtor payments in cases in which the court confirmed a plan. Some debtors may have filed for Chapter 13 relief only to obtain shortterm protection of the automatic stay and without the intention to confirm a Chapter 13 plan, or for more benign reasons some debtors

188. Due to the non-normality of these distributions, assumption-freer analyses are used (Kruskal-Wallis and median test).

189. As noted elsewhere, the available data do no reflect direct payments to creditors outside the plan, so the $70 \%$ figure understates the percentage of payments by Chapter 13 debtors to secured creditors. 
were unable to propose a confirmable plan. Excluding cases dismissed without confirmation of a plan, the average trustee disbursements to creditors naturally were greater than the average in all cases. Thus, as shown in Table 48 , the trustees disbursed an average of $\$ 11,858$ to all creditors in cases with a confirmed plan. They disbursed an average of $\$ 8,356$ to secured creditors, $\$ 1,419$ to priority creditors, and $\$ 2,155$ to general unsecured creditors. The median amounts paid to all, secured, priority, and general unsecured creditors were $\$ 5,308$, $\$ 2,667, \$ 0$, and $\$ 14$, respectively. (Table 52 below compares disbursements to the various classes of creditors in all cases with disbursements in cases with a confirmed plan and completed cases.) The larger average amounts indicate that relatively few debtors paid greater amounts of each category of debt. Even so, the fact remains that one half of all debtors who confirmed a plan paid essentially nothing to unsecured creditors.

TABLE 48. CREDITOR COLLECTIONS PER CASE: CASES WITH A CONFIRMED PLAN ${ }^{190}$

\begin{tabular}{|l|c|c|c|c|c|c|c|c|c|c|}
\hline Claims & $N$ & $\begin{array}{c}\text { \# cases } \\
\text { with } \\
\text { value } \\
\$ 0\end{array}$ & Range & Mean & SD & SEM & $25 \%$ & Median & $75 \%$ & $90 \%$ \\
\hline Secured & $\begin{array}{c}610 \\
(7 \text { missing })\end{array}$ & $\begin{array}{c}120 \\
(19 \%)\end{array}$ & $\$ 0-\$ 108,096$ & $\$ 8,356$ & $\$ 14,049$ & 568.83 & $\$ 229$ & $\$ 2,667$ & $\$ 9,685$ & $\$ 24,391$ \\
\hline Priority & $\begin{array}{c}610 \\
(7 \text { missing })\end{array}$ & $\begin{array}{c}351 \\
(57 \%)\end{array}$ & $\$ 0-\$ 54,598$ & $\$ 1,419$ & $\$ 5,126$ & 207.57 & $\$ 0$ & $\$ 0$ & $\$ 589$ & $\$ 2,934$ \\
\hline General & $\begin{array}{c}610 \\
(7 \text { missing })\end{array}$ & $\begin{array}{c}302 \\
(49 \%)\end{array}$ & $\$ 0-\$ 57,714$ & $\$ 2,155$ & $\$ 4,725$ & 191,31 & $\$ 0$ & $\$ 14$ & $\$ 2,650$ & $\$ 6,443$ \\
\hline Total & $\begin{array}{c}602 \\
(15 \text { missing })\end{array}$ & $\begin{array}{c}45 \\
(7 \%)\end{array}$ & $\$ 92-\$ 131,886$ & $\$ 11,858$ & $\$ 17,334$ & 706.47 & $\$ 1,333$ & $\$ 5,308$ & $\$ 15,155$ & $\$ 32,825$ \\
\hline
\end{tabular}

As discussed in greater detail above, the courts confirmed plans in $77.2 \%$ of the sample cases. Thirty-three percent (33\%) of all debtors, composing $42.7 \%$ of those with confirmed plans, completed their plans and received a discharge. Notably, as shown in Table 48 , the percentage of secured claims paid in cases with a confirmed plan was substantially higher than the percentage of secured claims paid in all cases. Whereas the figure for all cases was $30.6 \%$ (see Table 47 above), it was $74 \%$ in cases with a confirmed plan (see Table 49 ). This differential reflects the facts that secured claims must be paid 100 cents on the dollar (plus interest), whereas unsecured claims may be paid at a lower rate, and that the trustee normally distributes debtor payments first to secured creditors and then, after secured claims have been paid, to general unsecured creditors, so that in many cases

190. Due to the non-normality of these distributions, assumption-freer analyses are used (Kruskal-Wallis and median test). 
that were dismissed before discharge, the debtors paid at least some secured debt but little or no unsecured debt.

More striking, as further reported in Table 49 below, unsecured creditors collected little more in cases with a confirmed plan than in all cases. In cases with a confirmed plan, general unsecured creditors collected $20.2 \%$ of their claims, compared to $19.5 \%$ in all cases. The proportion of trustee distributions to general unsecured creditors was almost identical in the two groups $-18.1 \%$ of trustee distributions were to unsecured creditors in all cases, compared to $18.0 \%$ in cases with a confirmed plan.

TABLE 49. OVERALL CREDITOR COLLECTIONS: CASES WITH A CONFIRMED PLAN

\begin{tabular}{|l|c|c|c|c|}
\hline & Secured & Priority & General & All Claims \\
\hline $\begin{array}{l}\text { Total Allowed } \\
\text { Amount }\end{array}$ & $\$ 6,889,310$ & $\$ 923,359$ & $\$ 6,498,841$ & $\$ 14,701,826$ \\
\hline Total Payments & $\$ 5,097,420$ & $\$ 865,732$ & $\$ 1,314,433$ & $\$ 7,138,380$ \\
\hline $\begin{array}{l}\% \text { of Allowed } \\
\text { Claims Paid }\end{array}$ & $74.0 \%$ & $93.8 \%$ & $20.2 \%$ & $48.6 \%$ \\
\hline $\begin{array}{l}\% \text { of Total } \\
\text { Payments }\end{array}$ & $69.8 \%$ & $11.9 \%$ & $18.0 \%$ & $97.8 \%$ \\
\hline
\end{tabular}

\section{c. Completed Cases}

Naturally, the debtors who completed their plans paid greater amounts and percentages of their pre-bankruptcy debt than those whose cases were dismissed short of discharge. ${ }^{191}$ Tables 50 and 51 detail creditor collections per case and, overall, in cases in which the debtor obtained a discharge. As shown in Table 50, the Chapter 13 trustees in the Project districts disbursed an average of $\$ 18,413$ to all claimants in completed cases. They disbursed an average of $\$ 13,068$ to secured creditors, $\$ 1,732$ to priority creditors, and 4,696 to general creditors. The median trustee disbursements to all, secured, priority, and general unsecured creditors were $\$ 11,697, \$ 6,806, \$ 0$, and $\$ 3,151$, respectively.

191. Accord Gordon Bermant \& Ed Flynn, Bankruptcy by the Numbers, Measuring Projected Performance in Chapter 13: Comparisons Across the States, 19 AM. BANKR. INST. J. 22 (July/Aug. 2000) (analyzing 1998 data on trustee disbursements, concluding that "returns to unsecured creditors are higher when plans are completed"). 
TABLE 50. CREDITOR COLLECTIONS PER CASE: COMPLETED CASES

\begin{tabular}{|c|c|c|c|c|c|c|c|c|c|c|c|}
\hline Claims & $N$ & $\begin{array}{c}\# \text { cases } \\
\text { with } \\
\text { value }= \\
\$ 0\end{array}$ & Range & Mean & $S D$ & $S E M$ & $10 \%$ & $25 \%$ & Median & $75 \%$ & $90 \%$ \\
\hline Secured & $\begin{array}{c}258 \\
\text { (4 missing) }\end{array}$ & $\begin{array}{c}47 \\
(18 \%) \\
\end{array}$ & $\$ 0-\$ 108,096$ & $\$ 13,068$ & $\$ 17,434$ & 1085.4 & $\$ 0$ & $\$ 904$ & $\$ 6,806$ & $\$ 17,777$ & $\$ 39,012$ \\
\hline Priority & $\begin{array}{c}256 \\
(6 \text { missing) }\end{array}$ & $\begin{array}{c}136 \\
(52 \%) \\
\end{array}$ & $\$ 0-\$ 46,500$ & $\$ 1,732$ & $\$ 5,486$ & 342.9 & $\$ 0$ & $\$ 0$ & $\$ 0$ & $\$ 963$ & $\$ 3,326$ \\
\hline General & $\begin{array}{c}260 \\
\text { (2 missing) }\end{array}$ & $\begin{array}{c}25 \\
(10 \%) \\
\end{array}$ & $\$ 0-\$ 57,714$ & $\$ 4,696$ & $\$ 6,315$ & 391.7 & $\$ 10$ & $\$ 687$ & $\$ 3,151$ & $\$ 5,962$ & $\$ 10,701$ \\
\hline Total & $\begin{array}{c}253 \\
(9 \text { missing) }\end{array}$ & $12(5 \%)$ & $\$ 0-\$ 129,541$ & $\$ 18,413$ & $\$ 19,999$ & 1257.32 & $\$ 1,539$ & $\$ 5,633$ & $\$ 11,697$ & $\$ 25,579$ & $\$ 42,384$ \\
\hline
\end{tabular}

* due to the non-normality of these distributions, assumption-freer analyses are used (kruskal-wallis $\&$ median test; see table 6)

As shown in Table 51, with completion of a plan, the debtors paid over $100 \%$ of their secured and priority debts, reflecting the Code mandates for full payment, with interest, of such claims. Unsecured creditors collected $34.1 \%$ of their claims. Overall, creditors collected nearly $64 \%$ of their claims.

TABLE 51. CREDITOR COLLECTIONS: COMPLETED CASES

\begin{tabular}{|l|c|c|c|c|}
\hline & Secured & Priority & General & All Claims \\
\hline $\begin{array}{l}\text { Total Allowed } \\
\text { Amount }\end{array}$ & $\$ 3,080,838$ & $\$ 385,498$ & $\$ 3,583,771$ & $\$ 6,948,585$ \\
\hline Total Payments & $\$ 3,371,682$ & $\$ 443,488$ & $\$ 1,221,003$ & $\$ 4,658,559$ \\
\hline $\begin{array}{l}\% \text { of Allowed } \\
\text { Claims Paid }\end{array}$ & $109.4 \%$ & $115.0 \%$ & $34.1 \%$ & $67.0 \%$ \\
\hline $\begin{array}{l}\% \text { of Total } \\
\text { Payments }\end{array}$ & & & & $63.8 \%$ \\
\hline
\end{tabular}

Finally, Table 52 below compares disbursements to the various classes of creditors in all cases with disbursements in cases with a confirmed plan and completed cases.

TABLE 52. CREDITOR COLLECTIONS: COMPARISON OF AVERAGE AND MEDIAN AMOUNTS DISBURSED IN ALL CASES, CASES WITH CONFIRMED PLAN AND COMPLETED PLANS

\begin{tabular}{|l|c|c|c|}
\hline & All Cases & Confirmed Plan & Completed Plan \\
\hline Mean Secured & $\$ 6,593$ & $\$ 8,356$ & $\$ 13,068$ \\
\hline Median Secured & $\$ 1,141$ & $\$ 2,667$ & $\$ 6,806$ \\
\hline Mean Priority & $\$ 1,110$ & $\$ 1,419$ & $\$ 1,732$ \\
\hline Median Priority & $\$ 0$ & $\$ 0$ & $\$ 0$ \\
\hline Mean General & $\$ 1,683$ & $\$ 2,155$ & $\$ 4,696$ \\
\hline Median General & $\$ 0$ & $\$ 14$ & $\$ 3,151$ \\
\hline Mean Total & $\$ 9,406$ & $\$ 11,858$ & $\$ 18,413$ \\
\hline Median Total & $\$ 2,718$ & $\$ 5,308$ & $\$ 11,697$ \\
\hline
\end{tabular}




\section{Relationship Between Case Disposition and Creditor Repayment}

Predictably, case disposition was significantly related to the amount and type of debt repaid by the debtors in the sample cases. The more time a debtor spent in Chapter 13, the more debt she was likely to repay. As reported in Table 53 below, using a Spearman's rho statistical analysis, due to the abnormal distribution in the amounts of debt repaid by the debtors, time in Chapter 13 accounted for nearly 75\% of the variance in the total amount of debt (both principal and interest) that the debtors repaid. The relationship between time in Chapter 13 and the repayment of secured and unsecured debt separately was not so strong; time in Chapter 13 accounted for just over $50 \%$ of the variance in each of the amounts of these debts repaid by the debtors.

TABLE 53. CREDITOR COLLECTIONS AND TIME IN CHAPTER 13

$r:$ time in ch 13 and total debt (P\&I) repaid $r$ : time in ch 13 and total principal repaid $r$ : time in ch 13 and secured debt (P\&I) repaid

$r$ : time in ch 13 and gen. unsecured debt (P\&I) repaid $\mathrm{r}$ : time in ch 13 and priority debt (P\&I) repaid

$r$ : time in ch 13 and other debt (P\&I) repaid

\begin{tabular}{|c|c|c|}
\hline $\begin{array}{l}\text { Spearman's } \\
\text { rho }\end{array}$ & $p$ & $\begin{array}{l}\text { variance } \\
\text { accounted } \\
\text { for }\left(r h o^{\wedge} 2\right)\end{array}$ \\
\hline 0.864 & $<.001$ & $74.6 \%$ \\
\hline 0.861 & $<.001$ & $74.1 \%$ \\
\hline 0.722 & $<.001$ & $52.1 \%$ \\
\hline 0.715 & $<.001$ & $51.1 \%$ \\
\hline 0.427 & $<.001$ & $18.2 \%$ \\
\hline 0.089 & $<=.013$ & $0.8 \%$ \\
\hline
\end{tabular}
valid $N$ 753

761

761

Spearman's rho is used because debt repaid is not normally distributed 


\section{APPENDIX A DESIGN AND METHODOLOGY OF THE STUDY}

\section{A. The Study Sample and Choice of Districts}

The Chapter 13 Project is an empirical study of 795 Chapter 13 cases filed in 1994 in seven federal judicial districts comprising 14 Chapter 13 trusteeships. While we did not select the districts randomly, neither did we choose them based on any sense of how debtors and creditors in these districts fare in Chapter 13 cases. We chose the districts for several, mostly practical, reasons. (1) Collectively, these seven districts accounted for a very large portion - nearly 20\%-of Chapter 13 filings nationally in 1994. (2) Almost all of the Chapter 13 trustees in these districts use the same case management database system. The original plan for the study was to use specially-designed software to import into a common database information for all cases and all trustees in fourteen federal judicial districts. Unfortunately, the extraction program proved unworkable, and the Project therefore fell back to manually collecting all of the data and coding them into the Project database. We therefore reduced the number of districts in the study from fourteen to seven and selected a sample of cases from each of the seven districts. (3) Cases in two of the seven districts have been the subject of previous studies, ${ }^{192}$ providing some additional external checks of the validity of the Project's findings. (4) Case file information for these seven districts could be collected primarily from two Federal Records Centers (in East Point, Georgia, and Philadelphia, Pennsylvania), thereby limiting the costs of data collection.

The proportion of Chapter 13 filings in the districts covered by the Project was considerably higher than the proportion nationally. As reported in the following Table, in the seven judicial districts covered by the Chapter 13 Project, there were 79,688 consumer bankruptcy filings in 1994, with 47,393 , or $59.5 \%$, under Chapter 13 . Nationally, there were 778,190 consumer bankruptcy filings in 1994 . Of these,

192. See Jean Braucher, An Empirical Study of Debtor Education in Bankruptcy: Impact on Chapter 13 Completion Not Shown, 9 AM. BaNkr. INST. L. REv. 557, 577-79 (2001) (study of Chapter 13 cases filed in five judicial districts in 1994 and 1997, including the Middle District of North Carolina); Teresa A. Sullivan, Elizabeth Warren \& Jay L. Westbrook, Consumer Debtors Ten Years Later: A Financial Comparison of Consumer Bankrupts 1981-1991, 68 AM. BANKR. L.J. 121 (1994) (reporting on study of chapter 7 and chapter 13 cases filed in 1991 in ten judicial districts, including the Western District of Pennsylvania); Teresa A. Sullivan, Elizabeth Warren \& Jay L. Westbrook, As We Forgive Our Debtors: Bankruptcy and Consumer Credit in America (1989) (reporting on study of chapter 7 and chapter 13 cases filed in 1981 in the same judicial districts, including the Western District of Pennsylvania); Teresa A. Sullivan, Elizabeth Warren \& Jay L. Westbrook, Folklore and Facts: A Preliminary Report from the Consumer Bankruptcy Project, 60 AM. BANKR. L.J. 293, 324 (1986) (same). 
240,639 , or nearly $31 \%$, were Chapter 13 filings. ${ }^{193}$ The ratio of Chapter 13 filings to total consumer filings was above the national average in five of the sample districts and below the national average in twothe District of Maryland and the Western District of Pennsylvania. ${ }^{194}$ Consumer Bankruptcy Filings, 1994

\begin{tabular}{|l|c|c|c|}
\hline \multicolumn{1}{|c|}{ District } & $\begin{array}{c}\text { Total Consumer } \\
\text { Filings }\end{array}$ & $\begin{array}{c}\text { Chapter 13 } \\
\text { Filings }\end{array}$ & $\begin{array}{c}\text { Percent } \\
\text { Chapter 13 } \\
\text { Filings }\end{array}$ \\
\hline NDGA & 24,686 & 16,466 & $66.6 \%$ \\
\hline SDGA & 6,822 & 5,173 & $75.8 \%$ \\
\hline MDTN & 8,648 & 4,794 & $55.4 \%$ \\
\hline WDTN & 16,083 & 12,972 & $80.7 \%$ \\
\hline MDNC & 4,201 & 3,161 & $75.2 \%$ \\
\hline WDPA & 4,976 & 840 & $16.9 \%$ \\
\hline DMD & 14,272 & 3,987 & $27.9 \%$ \\
\hline Seven Districts & 79,688 & 47,393 & $59.5 \%$ \\
\hline United States & 778,190 & 240,639 & $30.9 \%$ \\
\hline
\end{tabular}

\section{B. Data Collection and Coding}

The Project relied on data from Chapter 13 trustee records, select portions of the bankruptcy court case files, and PACER (Public Access to Court Electronic Records), ${ }^{195}$ an on-line, electronic public-access service, which is maintained by the bankruptcy court clerk's office in each district, that allows users to obtain case and docket information, including information on other bankruptcy filings by a bankruptcy debtor. In addition, we surveyed the Chapter 13 trustees in the seven

193. See infra note 1. See generally Gordon Bermant, Ed Flynn, \& Karen Bakewell, Bankruptcy by the Numbers, Thoughts on the "Local Legal Culture," The Case of Consumer Chapter Choice, 21 AM. BANKR. INST. J. 24 (Feb. 2002) (reviewing data on the variation among districts and states in percentages of consumer debtors who choose Chapter 13 or Chapter 7); Teresa A. Sullivan, Elizabeth Warren \& Jay L. Westbrook, Who Uses Chapter 13?, Paper presented at the annual meeting of the Law and Society Association, Budapest (2001) (copy on file with the author) (analyzing various factors influencing choice of chapter, based on data in 1981, 1991, and 1999 studies); Gordon Bermant, Ed Flynn, \& Karen Bakewell, Bankruptcy by the Numbers, A Tale of Two Chapters, Part I, 21 AM. BANKR. InST. J. 20 (July/Aug. 2002) (same); Gordon Bermant, Bankruptcy by the Numbers, Exploring the Demographics of Consumer Chapter Choice, 18 Am. BANKR. INST. J. 26 (May 1999) (finding that the "percentage of chapter 13 filings in a state tend to vary directly with the numbers of filings per 1000 households in the state").

194. As discussed supra, notes 9-13 and accompanying text, the fact that most of the sample districts have a higher proportion of Chapter 13 filings than the national average did not detract from the representativeness of the sample. Rather, the representativeness of the sample is likely a result of the fact that the districts included in the sample contain a large proportion, nearly $20 \%$, of all Chapter 13 filings in 1994.

195. For a description of the PACER system, see http://pacer.psc.uscourts.gov/ pacerdesc.html. 
districts covered by the study regarding relevant district and trustee practices in effect in 1994. The Project did not collect data from any other sources, for example, debtor questionnaires or interviews. While almost all of the Chapter 13 trustees in the districts covered by the study were cooperative and provided all requested information on their cases, several did not and in their cases we were restricted to data that could be obtained from the bankruptcy case files and PACER.

The Project collected extensive data on most of the sample cases, including the following: case number; district; trustee; judge; debtor's attorney; whether the petition was individual or joint; the gender of the petitioner; whether the petitioner was doing business under another name; zip code; county; dates of filing, first meeting of creditors, and case closing; case disposition - dismissal before confirmation, dismissal after confirmation, conversion before confirmation, conversion after confirmation, or discharge; the number and amounts of secured, priority, general, and other claims; amounts paid to creditors, debtor's attorney, and the trustee; whether payments were made by payroll deduction; dates of last payment to attorney and trustee; proposed and actual plan length; proposed percentage payment to unsecured creditors; whether any creditor payments were to be made outside the plan, and the amounts thereof; number of persons and dependants in debtor's household; debtor and household gross income, net income, and living expenses; attorneys' fees; and previous and subsequent bankruptcy filings. A copy of the Project Coding Sheet is included as Appendix B.

Data were coded and entered into a spreadsheet twice, by two different research assistants, with conflicts resolved either by doublechecking the source or by decision of the authors.

C. Methodology

The Project seeks to measure the fresh start and rehabilitation features of Chapter 13 by determining the rates of discharge, dismissal, and conversion in the sample judicial districts and by ascertaining the proportion of debtors who have filed previous and subsequent bankruptcies. Regarding creditor repayment, we gathered data on the types and amounts of debt repaid by the debtors in the Chapter 13 Project, as well as by debtors in all districts covered by the United States Trustee Program over the past ten years. By comparing completed cases with dismissed and converted cases, the Project investigates the relation between case outcome and factors such as debtor income, plan length, distribution to unsecured creditors, income retained for payment of household expenses, and previous bankruptcy filings. 
APPENDIX B CHAPTER 13 PROJECT CODING SHEET

\section{Part I - Chapter 13 Trustee's Complete Print Inquiry}

\section{A - INFORMATION FROM PAGE 1}

DISTRICT

INDEX \# TRUSTEE

JOINT/INDIV 1 Individual 2 Joint

GENDER (for indiv. Filing only) 1 Male 22 Female 3 Unsure $\mathrm{D} / \mathrm{B} / \mathrm{A} \quad 1 \quad \mathrm{Yes} \quad \mathrm{d} / \mathrm{b} / \mathrm{a} \quad 2$ No $d / b / a$ ZIP CODE FILING DATE (mm/dd/yy)

1st MTNG DATE (mm/dd/yy) CONF. DATE (mm/dd/yyyy) CLOSE DATE (mm/dd/yy) CLOSE CODE $\begin{array}{lllll}\text { DISBURSEMENT } & 1 & \text { Yes } & 2 & \text { No }\end{array}$ COMPANION(S) JUDGE DEBTOR'S ATTORNEY PLAN BASE BALANCE ON HAND TOTAL PAID IN PAID TO CREDITORS ATTY FEE DUE ATTY FEE PD TO BE CURRENT TRUSTEE FEE PAID

FILING FEE PAID NOTICE FEE PD TOTAL DISBURSED $\%$ TO UNSECURED DATE OF FINAL DISPOSITION (mm/dd/yy) DEBTOR \# 1 PAYROLL DEDUCTION (amount) PAYROLL DEDUCTION SCHEDULE

1 Monthly 3 Bi-weekly 5 Quarterly

DEBTOR \# 1 DIRECT PAYMENT (amount) DIRECT PAYMENT SCHEDULE

DEBTOR \# 2 PAYROLL DEDUCTION (amount) PAYROLL DEDUCTION SCHEDULE

DEBTOR \# 2 DIRECT PAYMENT (amount) DIRECT PAYMENT SCHEDULE

DEBTOR \# 1 SSN CONT. DEBT ARREARS
1 Monthly

3 Bi-weekly

5 Quarterly

\section{)}

1 Monthly

3 Bi-weekly

5 Quarterly

1 Monthly

3 Bi-weekly

5 Quarterly DEBTOR \# 2 SSN CONT. PMTS.
2 Bi-monthly

4 Weekly

6 Yearly
2 Bi-monthly

4 Weekly

6 Yearly 2 Bi-monthly 4 Weekly 6 Yearly 2 Bi-monthly 4 Weekly 6 Yearly REG PMTS. 


\section{B-DISBURSEMENT INFORMATION}

DEBTOR REFUND DATE OF LAST PMNT TO ATTY (mm/dd/yy) DATE OF LAST PAYMENT TO TRUSTEE $(\mathrm{mm} / \mathrm{dd} / \mathrm{yy})$

\section{C-CLAIM RECORDS INFORMATION}

TOTAL \# OF PRIORITY CLAIMS _ TOTAL \# OF SECURED CLAIMS TOTAL \# OF OTHER CLAIMS — TOTAL \# OF UNSECURED CLAIMS (Description, e.g., co-signed, nondischargeable, etc.)

\section{*PRIORITY CLAIM \# 1}

SCHED

INT \% VALUE INTPD CRED \% CLAIM TOTPD

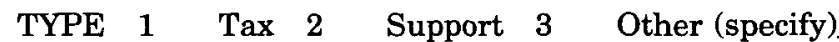

PAID OUTSIDE OF PLAN? 1 Yes 2 No

\section{*PRIORITY CLAIM \# 2}

SCHED VALUE CLAIM TOTPD INT \% INTPD CRED \%

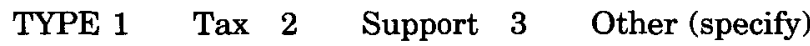
PAID OUTSIDE OF PLAN? 1 Yes 2 No

\section{*PRIORITY CLAIM \# 3}

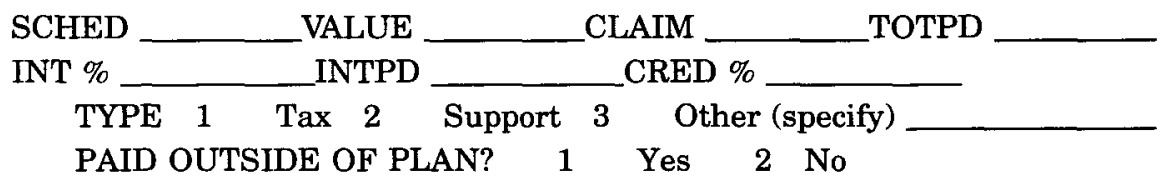

\section{*SECURED CLAIM \# 1}

SCHED INT \% VALUE INTPD CRED \% CLAIM TYP

TYPE

Mortgage

3 Second Mortgage

5 Third Mortgage

7 Car (Year and Make)

8 Household Goods (HHG) 9 Other (specify) PER MO.

2 Mortgage Arrearage

4 2d Mortgage Arrearage

$63 \mathrm{~d}$ Mortgage Arrearage

PAID OUTSIDE THE PLAN? 1 Yes 2 No 
*SECURED CLAIM \# 2

SCHED VALUE

INT \% INTPD CLAIM TOTPD
TYPE 1 Mortgage
3 Second Mortgage
5 Third Mortgage
2 Mortgage Arrearage
4 2d Mortgage Arrearage
7 Car (Year and Make)
8 Household Goods (HHG) 9 Other (specify)
6 3d Mortgage Arrearage CRED \% PER MO.

PAID OUTSIDE THE PLAN? 1 Yes 2 No

\section{*SECURED CLAIM \# 3}

SCHED VALUE

INT \% INTPD CLAIM TOTPD
TYPE 11 Mortgage
3 Second Mortgage
5 Third Mortgage
7 Car (Year and Make)
8 Household Goods (HHG) 9 Other (specify)
2 Mortgage Arrearage
4 2d Mortgage Arrearage
6 3d Mortgage Arrearage CRED \% PER MO.

PAID OUTSIDE THE PLAN? 1 Yes 2 No

\section{*SECURED CLAIM \# 4}

\begin{tabular}{crllll} 
SCHED & & \multicolumn{1}{c}{ VALUE } & CLAIM & TOTPD \\
INT \% & & INTPD & CRED $\%$ & & PER MO. \\
\cline { 3 - 4 } TYPE & 1 & Mortgage & 2 & Mortgage Arrearage \\
& 3 & Second Mortgage & 4 & 2d Mortgage Arrearage \\
& 5 & Third Mortgage & 6 & 3d Mortgage Arrearage \\
& 7 & Car (Year and Make) & & \\
& 8 & Household Goods (HHG) & 9 & Other (specify) \\
\hline
\end{tabular}
PAID OUTSIDE THE PLAN? 1 Yes 2 No

\section{*SECURED CLAIM \# 5}

SCHED INT \% VALUE INTPD

TYPE 11 Mortgage

3 Second Mortgage

5 Third Mortgage CRED \% CLAIM PER MO.

2 Mortgage Arrearage

4 2d Mortgage Arrearage

6 3d Mortgage Arrearage

7 Car (Year and Make)

8 Household Goods (HHG) 9 Other (specify) 
*SECURED CLAIM \# 6

SCHED VALUE

INT \% INTPD CLAIM TOTPD

TYPE 1 Mortgage CRED \% MO.

3 Second Mortgage

5 Third Mortgage

7 Car (Year and Make)

8 Household Goods (HHG) 9 Other (specify) PAID OUTSIDE THE PLAN? 1 Yes 2 No

2 Mortgage Arrearage

4 2d Mortgage Arrearage

6 3d Mortgage Arrearage

*SECURED CLAIM \# 7

SCHED VALUE

INT \% INTPD CLAIM TOTPD

TYPE 11 Mortgage CRED \% PER MO

3 Second Mortgage $\quad 4$ 2d Mortgage Arrearage

5 Third Mortgage 6 3d Mortgage Arrearage

7 Car (Year and Make)

8 Household Goods (HHG) 9 Other (specify)

PAID OUTSIDE THE PLAN? 1 Yes 2 No

\section{D - INFORMATION FROM LAST PAGE}

\section{*TOTAL PRIORITY}

SCHEDULED VALUE PRINCIPAL PAID INTEREST PD CLAIM AMT

*TOTAL SECURED

SCHEDULED VALUE CLAIM AMT

PRINCIPAL PAID INTEREST PD

\section{*TOTAL UNSECURED}

SCHEDULED VALUE CLAIM AM'T PRINCIPAL PAID INTEREST PD

\section{*TOTAL OTHER}

SCHEDULED VALUE PRINCIPAL PAID INTEREST PD CLAIM AMT

\section{Part II - Court Files A - FROM THE PETITION}

COUNTY OF RESIDENCE 


\section{B - FROM THE PLAN}

PLAN LENGTH (months) PERCENT TO UNSECUREDS -\% PROPOSED PAYMENTS TO TRUSTEE (amount) payment SCHEDULE

1 Monthly

3 Bi-weekly 5 Quarterly 2 Bi-monthly 4 Weekly 6 Yearly \# OF SECURED CLAIMS TO BE PAID DIRECT/OUTSIDE OF PLAN AMT OF DIRECT SECURED CLAIM \# 1 AMT OF DIRECT SECURED CLAIM \# 2 AMT OF DIRECT SECURED CLAIM \# 3 AMT OF MO. PMT. AMT OF MO. PMT. \# OF PRIORTTY CIAIMS TO BE PAID AMT OF DIRECT PRIORITY CLAIM \# 1 AMT OF DIRECT PRIORITY CLAIM \# $2 \_$AMT OF MO. PMT. AMT OF MO. PMT. DIRECT/OUTSIDE OF PLAN AMT OF MO. PMT. \# OF UNSECURED CLAIMS TO BE PAID DIRECT/OUTSIDE OF PLAN _ AMT OF DIRECT UNSECURED CLAIM \# 1 AMT OF DIRECT UNSECURED CLAIM \# 2 AMT OF MO. PMT. AMT OF MO. PMT.

\section{C - FROM SCHEDULES I AND J}

NUMBER IN HH (including DR) NUMBER OF DEPENDANTS DEBTOR GROSS MONTHLY INCOME SPOUSE GROSS MONTHLY INCOME DEBTOR NET MONTHLY EXPENSES SPOUSE NET

\section{D - FROM STATEMENT OF FINANCIAL AFFAIRS}

PREPETITION ATTY FEE PAYMENT FOR BANKRUPTCY REPRESENTATION

\section{Part III - Previous and Subsequent Filings}

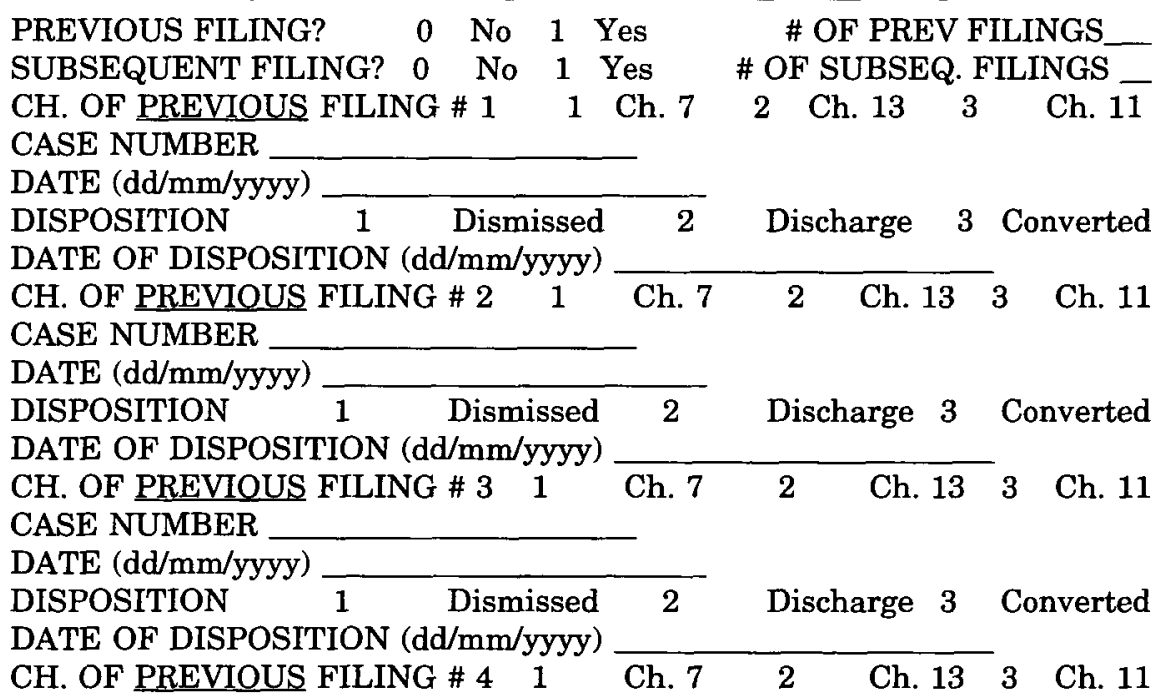


CASE NUMBER

DATE (dd/mm/yyyy)

DISPOSITION

$1 \quad$ Dismissed 2

Discharge 3 Converted

DATE OF DISPOSITION (dd/mm/yyyy)

$\begin{array}{lllllll}\text { CH. OF PREVIOUS FILING \# } 5 & 1 & \text { Ch. } 7 & 2 & \text { Ch. } 13 & 3 & \text { Ch. } 11\end{array}$

CASE NUMBER

DATE $(\mathrm{dd} / \mathrm{mm} / \mathrm{yyyy})$

DISPOSITION

1

Dismissed 2

Discharge 3 Converted

DATE OF DISPOSITION (dd/mm/yyyy)

CH. OF SUBSQ. FILING \# 111 Ch. 7

CASE NUMBER

DATE (dd/mm/yyyy)

DISPOSITION 1

1 Dismissed 2

Discharge 3 Converted

DATE OF DISPOSITION (dd/mm/yyyy)

$\begin{array}{lllllll}\text { CH. OF SUBSQ. FILING \# } 2 & 1 & \text { Ch. } 7 & 2 & \text { Ch. } 13 & 3 & \text { Ch. } 11\end{array}$

CASE NUMBER

DATE (dd/mm/yyyy)

DISPOSITION

1 Dismissed 2

Discharge 3 Converted

DATE OF DISPOSITION (dd/mm/yyyy)

$\begin{array}{lllllll}\text { CH. OF SUBSQ. FILING \# } 3 & 1 & \text { Ch. } 7 & 2 & \text { Ch. } 13 & 3 & \text { Ch. } 11\end{array}$

CASE NUMBER

DATE (dd/mm/yyyy)

DISPOSITION 11 Dismissed $2 \quad$ Discharge 3 Converted

DATE OF DISPOSITION (dd/mm/yyyy)

CH. OF SUBSQ. FILING \# 41 Ch. $7 \quad 2 \quad \begin{array}{lllll} & 1 & \text { Ch. } 13 & 3 & \text { Ch. 11CASE }\end{array}$

NUMBER

DATE (dd/mm/yyyy)

DISPOSITION1 11 Dismissed $2 \quad$ Discharge 3 Converted

DATE OF DISPOSITION (dd/mm/yyyy)

\section{TABLE OF TABLES AND FIGURES}

Table 1. Gender of Petitioners

Table 2. Household Size of Petitioners by Gender

Table 3. Household Size of Petitioners (frequency)

Table 4. Number of Dependents by Gender

Table 5. Number of Dependents Per Household (frequency)

Table 6. Debtor and Household, Annual Gross and Net Income

Table 7. Annual Gross Income by Gender of Petitioner

Table 8. Debtor Indebtedness-Allowed Claims

Table 9. Debt-Annual Net Income Ratios (Excluding Long-Term Mortgage Debt)

Table 10. Frequency of Homeownership by District

Table 11. Previous and Subsequent Filings

Table 12. Chapter of Previous Bankruptcy Filing

Table 13. Chapter of Subsequent Bankruptcy Filing

Table 14. Interval Between Disposition of Previous Case and Filing of Sample Case 
Table 15. Interval Between Disposition of Sample Case and Filing of Subsequent Case

Table 16. Outcome in Previous Case (regardless of chapter)

Table 17. Outcome in Subsequent Case (regardless of chapter)

Table 18. Discharge, Dismissal, and Conversion Rates - All Cases

Table 19. Discharge, Dismissal, and Conversion Rates - All Cases, by District

Table 20. Discharge, Dismissal, and Conversion Rates, Excluding Cases

Dismissed or Converted Before Confirmation

Table 21. Discharge, Dismissal, and Conversion Rates, Excluding Cases

Dismissed or Converted Before Confirmation - by District

Table 22. Comparison of Discharge, and Dismissal/Conversion Before Confirmation Rates, by District

Table 23. Case Disposition by Gender

Table 24. Filing Status by Case Disposition

Table 25. Debtor Income and Discharge in Chapter 13

Table 26. Creditor Claims in Completed and Dismissed Cases

Table 27. Debtor and Household Debt-Annual Net Income Ratios and Case Outcome

Table 28. Previous Filings and Case Outcome, by Number of Previous Filings

Table 29. Previous Filings and Case Outcome, by Case Outcome

Table 30. Case Outcome and Subsequent Filings, by Case Outcome

Table 31. Proposed Plan Payments and Retained Income

Table 32. Household Retained Income in Completed and Dismissed Cases

Table 33. Proposed Distributions to Unsecured Creditors

Table 34. Proposed Levels of Repayment on Unsecured Claims

Table 35. Case Outcome and Proposed Distributions to Unsecured Creditors

Table 36. Proposed Length of Debtor Plans

Table 37. Proposed Length of Plan in Completed and Dismissed Cases

Table 38. Inter-District Comparisons of Proposed Length of Debtor Plans (in Months)

Table 39. Case Disposition and Time in Chapter 13 (in months)

Table 40. Case Disposition and Disparity Between Proposed Plan Length and Actual Time in Chapter 13 (in months)

Table 41. Chapter 13 Trustee Disbursements/National, FY 1994-2003

Table 42. Average Chapter 13 Disbursements per Case (USTP), 1994-2003

Table 43. Chapter 13 Trustee Disbursements/Sample Districts, FY 1994

Table 44. Chapter 13 Trustee Disbursements/Sample Districts, FY 2003

Table 45. Allowed Claims in All Sample Cases

Table 46. Creditor Collection Per Case: All Cases

Table 47. Overall Creditor Collections: All Cases

Table 48. Creditor Collections Per Case: Cases with a Confirmed Plan

Table 49. Overall Creditor Collections: Cases with a Confirmed Plan

Table 50. Creditor Collections Per Case: Completed Cases

Table 51. Creditor Collections: Completed Cases 
Table 52. Creditor Collections: Comparison of Average and Median Amounts Disbursed in All Cases, Cases with Confirmed Plan and Completed Plans

Table 53. Creditor Collections and Time in Chapter 13

Figure 1. Mean Debtor Debt-Annual Net Income Ratio by District

Figure 2. Mean Debtor Household Debt-Annual Net Income Ratio by District

Figure 3. Sample Cases with Record of Other Filings

Figure 4. Subsequent Refiling Rates by District 
